\author{
Universidade de São Paulo \\ Escola Politécnica \\ Departamento de Engenharia de Produção
}

\title{
O Processo de Inovação nas Indústrias de Pequeno e Médio Porte do Estado de São Paulo - Setores da Eletro Eletrônica e Telecomunicações.
}

José Roberto Tálamo

Dissertação apresentada à Escola Politécnica da Universidade de São Paulo - Departamento de Engenharia de Produção - como parte do processo de obtenção do título de Mestre em Engenharia.

Orientador: Professor Doutor Roberto Gilioli Rotondaro

São Paulo

2001 
Tálamo, José Roberto

O Processo de Inovação nas Indústrias de Pequeno e Médio Porte do Estado de São Paulo - Setores da Eletro Eletrônica e Telecomunicações.

Dissertação apresentada à Escola Politécnica da Universidade de São Paulo - Departamento de Engenharia de Produção - para o obtenção do título de Mestre em Engenharia.

Áreas de Concentração:

1. Inovação. 2. Tecnologia. 3. Qualidade.

4. Aprendizado.

Orientador:

Prof. Dr. Roberto Giglioli Rotondaro 


\section{DEDICATÓRIA}

Aos meus pais, Julieta, que se entusiasmou por esta empreitada mas não pode ver sua conclusão e Waldomiro, sempre interessado e participante.

Aos meus filhos, Roberta, Isadora e Fernão, razões absolutas de minha vida.

A Maria de Fátima, na turbulência ou na calmaria, sempre minha musa e meu estímulo. 


\section{AGRADECIMENTOS}

Ao meu orientador, Prof. Dr. Roberto Gilioli Rotondaro, por sua dedicação e amizade, o que tornou a elaboração desta dissertação, uma atividade agradável e gratificante.

Ao Professor Fernando Bresciani, Diretor da Faculdade de Engenharia Industrial, pelo seu empenho na constituição do convênio de Mestrado com a Universidade de São Paulo, o que possibilitou este trabalho, e por sua dedicação e interesse, sempre acompanhando cada etapa.

Aos Professores Doutores Marly Monteiro e Oduvaldo Vendrametto cuja leitura crítica e sugestões a este trabalho, permitiram seu aperfeiçoamento.

Aos professores que ministraram as disciplinas do Mestrado, em especial aos Professores Drs. Márcia Terra, Israel Brunstein e Paulino G. Francischini.

Aos funcionários do setor de Pós Graduação da Escola Politécnica da Universidade de São Paulo.

Aos colaboradores do SEBRAE - Diadema, na pessoa do Eng. José Lourenço Melro. 


\section{SUMÁRIO}

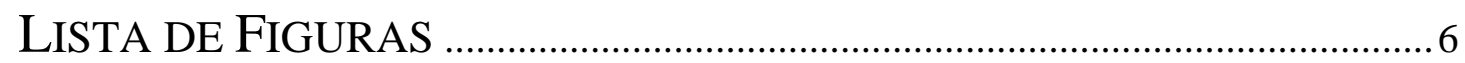

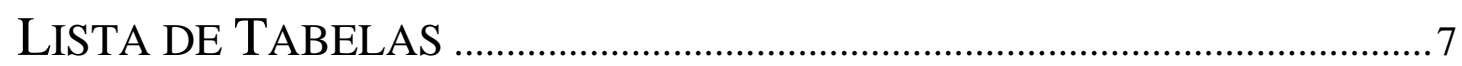

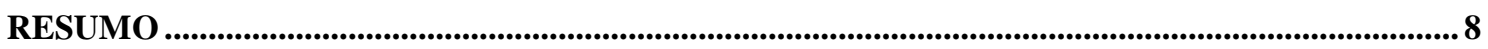

ABSTRACT ................................................................................................................................9

INTRODUÇÃO

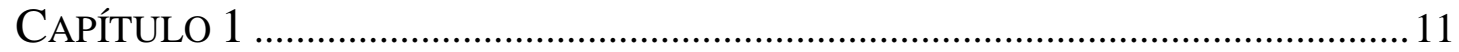

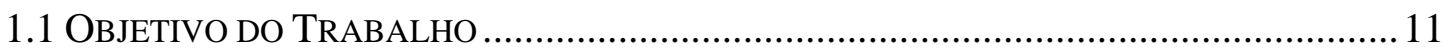

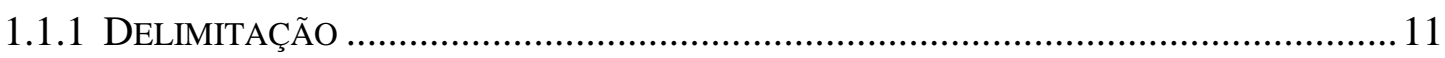

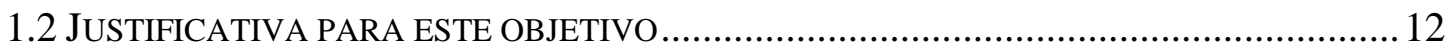

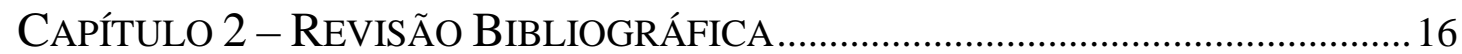

2. 1 A INOVAÇÃO: DEFINIÇÃO, TIPOS E SEU ASPECTO ESTRATÉGICO. ................................16

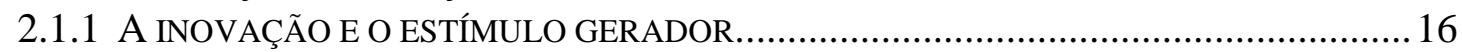

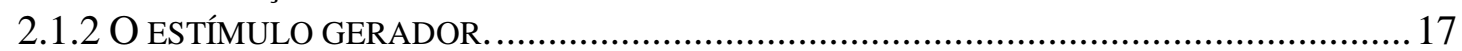

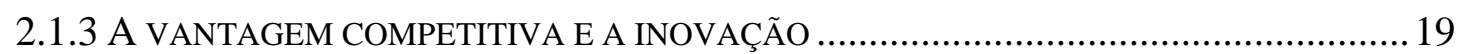

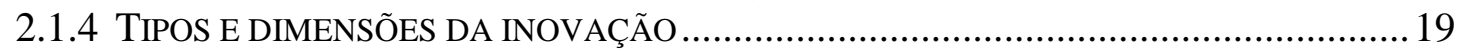

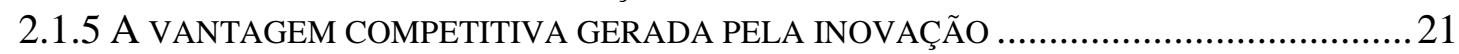

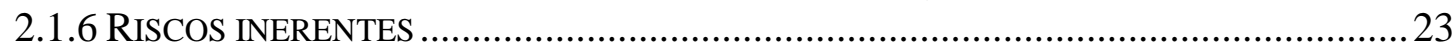

2.2 A VIDA DO PRODUTO E A TRANSFORMAÇÃO DA INOVAÇÃO ………………………....2

2.2.1 O CICLO DE VIDA DO PRODUTO E A FREQÜÊNCIA DA INOVAÇÃO ………………......2

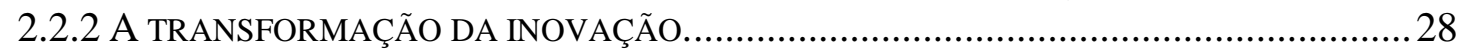

2.3 COMO SE DESENVOLVE O PROCESSO DE INOVAÇÃO DENTRO DA EMPRESA ................29

2.3.1 RASTREAMENTO DO AMBIENTE INTERNO E EXTERNO................................................30

2.3.2 ESTRATÉGIA - ESCOLHA DA OPORTUNIDADE MAIS ADEQUADA ………………........... 30

2.3.3. OBTENÇÃO DOS RECURSOS NECESSÁRIOS (P\&D, TECNOLOGIA, FINANCIAMENTOS,

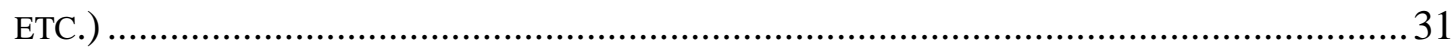

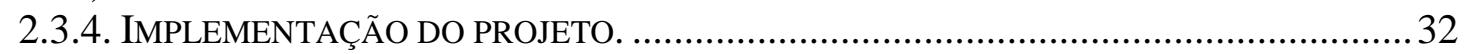

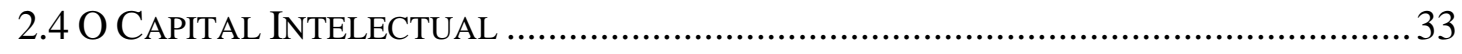

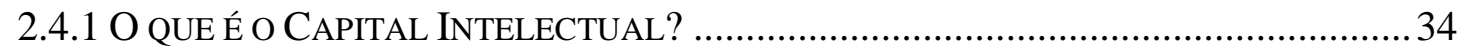

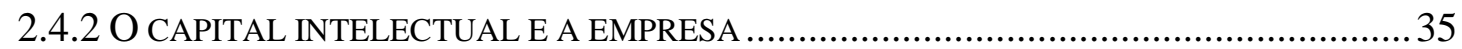

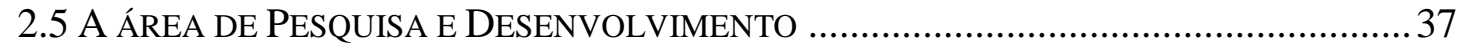

2.5.1 A INFLUÊNCIA DA POLÍTICA NACIONAL ............................................................... 37

2.5.1.1 UM INDICADOR NACIONAL DA POLÍTICA DE INVESTIMENTO EM INOVAÇÃO........38

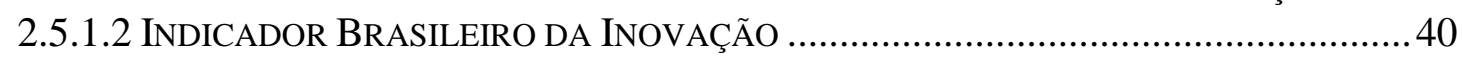

2.6 FoNTES DE INOVAÇÃO - PORQUE BUSCAR A PARCERIA ………………………....... 43

2.6.1 AS PRINCIPAIS FORMAS DE COLABORAÇÃO ……………................................. 45

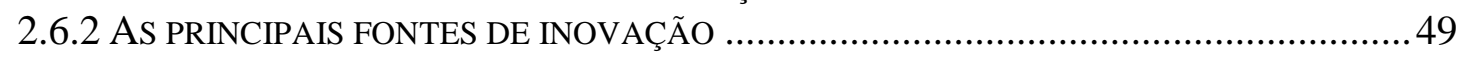

2.7 AS FERRAMENTAS DA QUALIDADE E A INOVAÇÃO..................................................52

2.7.1 BENCHMARKING - (TESTES DE NÍVEL E DE DESEMPENHO) …………….................54

2.7.2 DFQ - O DESDOBRAMENTO DA FUNÇ̃̃o QUALIDADE (QFD) ……………….......55

2.7.2.1 O PROCESSO DE DFQ ............................................................................57

2.7.2.2 OS POSSÍVEIS RESULTADOS DA APLICAÇÃO DO DFQ.........................................59

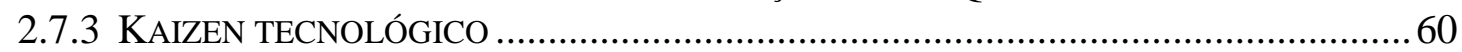

2.8 DINÂMICA DA INOVAÇÃO - COMO ELA SE PROCESSA...............................................63 


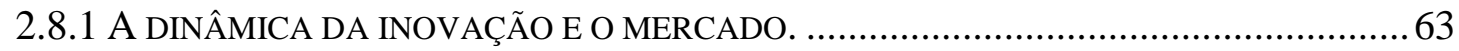

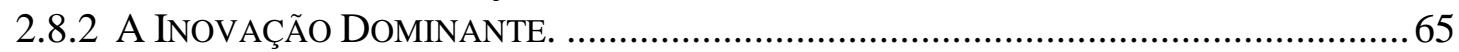

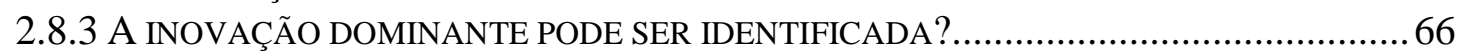

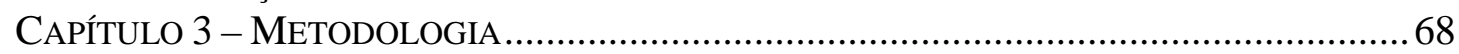

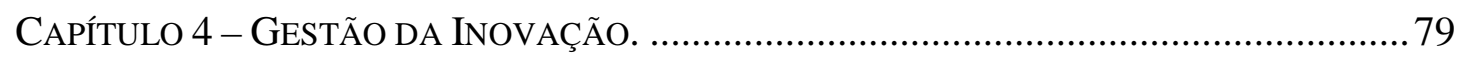

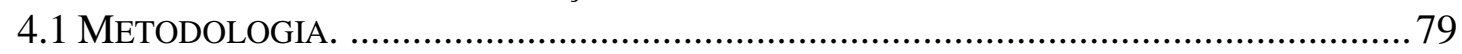

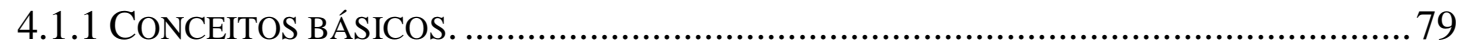

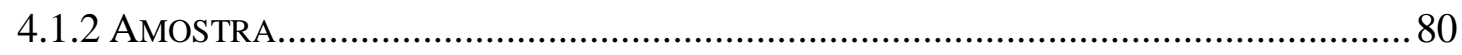

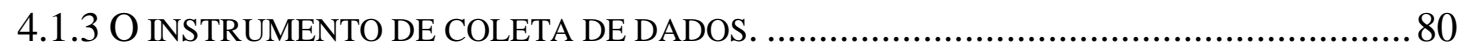

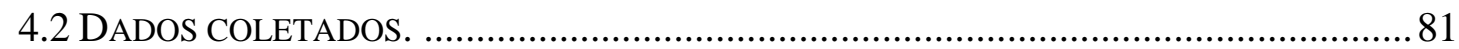

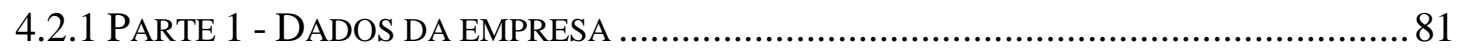

4.2.1.1 PERFIL PROFISSIONAL DE QUEM RESPONDEU AO QUESTIONÁRIO. ....................... 81

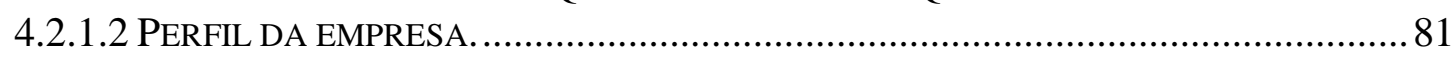

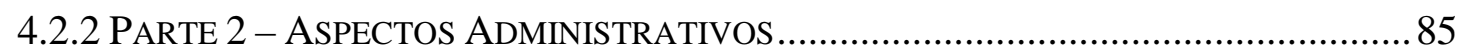

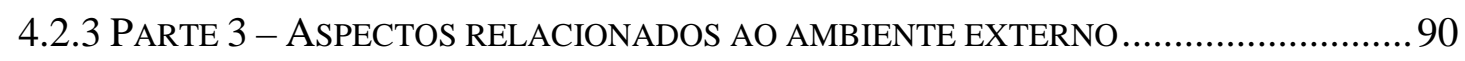

4.2.4 PARTE 4 - MECANISMOS DE IMPLEMENTAÇÃO ................................................ 92

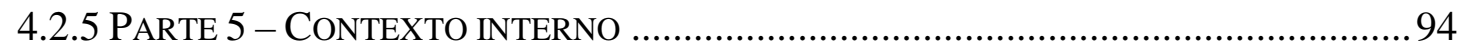

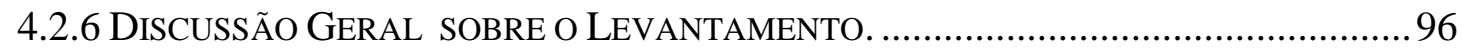

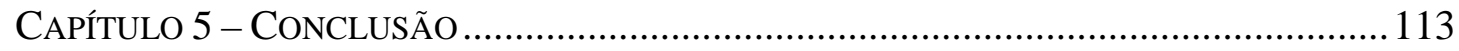

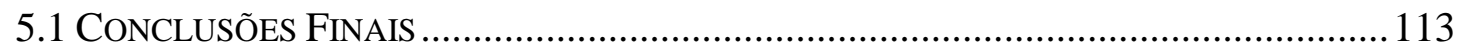

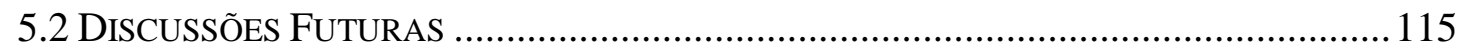




\section{Lista de Figuras}

Figura 1: As cinco forças competitivas que interferem na empresa..................................... 18

Figura 2: Grau de percepção da inovação sob a ótica do cliente.............................................. 20

Figura 3: Posição de mercado e percentual de vendas referentes a novos produtos.......... 21

Figura 4: A incerteza do meio ambiente da empresa e a resposta da empresa ................... 25

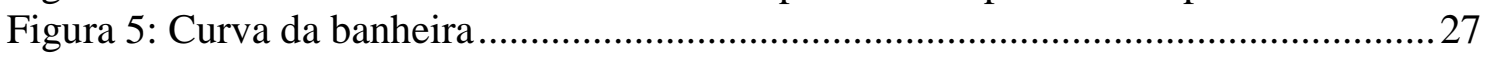

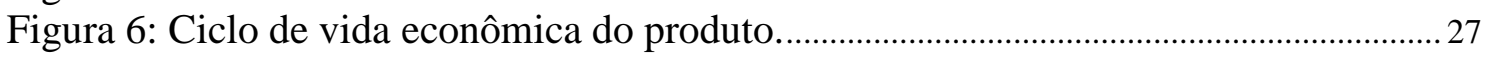

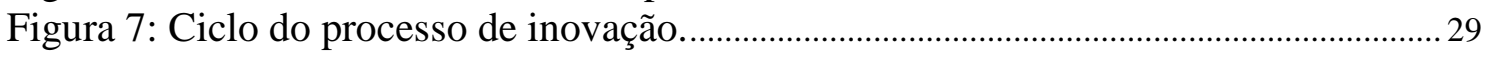

Figura 8: Evolução do percentual médio do PIB, investido em atividades voltadas à

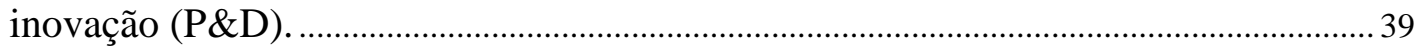

Figura 9 : Evolução média do percentual do PIB aplicado em P\&D, comparada à evolução do percentual do Brasil......................................................................................... 41

Figura 10 : Participação de cada setor da economia nos gastos com Ciência e Tecnologia.

Figura 11: Importância relativa das diversas fontes de inovação ................... 52

Figura 12 : Princípios do DFQ associados ao desenvolvimento de novos produtos .......55

Figura 13: Método tradicional de desenvolvimento de um novo produto ............................ 56

Figura 14: Método otimizado para desenvolvimento de um novo produto - DFQ..........57

Figura 15: Matriz do Desdobramento da Função Qualidade - Casa da Qualidade ............58

Figura 16: O kaizen esquematizado como uma seqüência de ciclos PDCA........................61

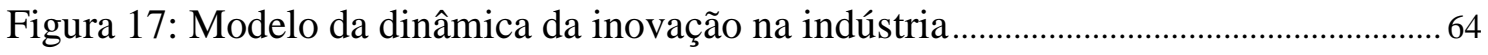

Figura 18: Número de empresas automobilísticas em operação nos EUA.................................... 66

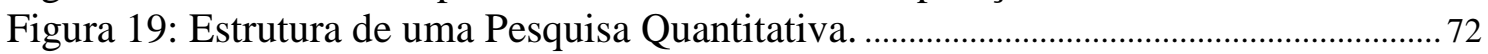

Figura 20: Fontes de inovação mais lembradas pelos pesquisados ........................................ 98

Figura 21: Veículos indicadores de inovação mais lembrados pelos pesquisados ............. 99

Figura 22: Localização das maiores oportunidades de inovação. ………………………....... 100

Figura 23: Localização das maiores competências empresariais.......................................... 100

Figura 24: Distribuição (\%) de engenheiros e cientistas ativos em pesquisa e

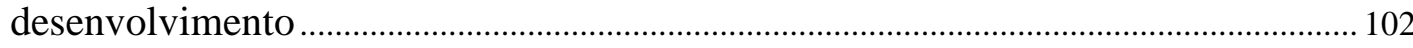

Figura 25: Distribuição de engenheiros e cientistas, em pesquisa e desenvolvimento -

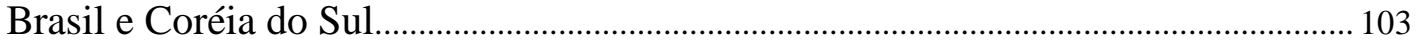

Figura 26: Gasto em P\&D das empresas privadas, como \% do PIB .................................... 114 


\section{Lista de Tabelas}

Tabela 1 :Vantagem competitiva em função do tipo de inovação utilizada..........................22

Tabela 2 : Tendência de gastos em Pesquisa e Desenvolvimento (P\&D), expressos como percentagem do PIB.

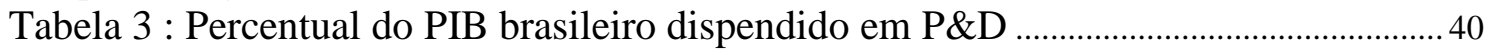

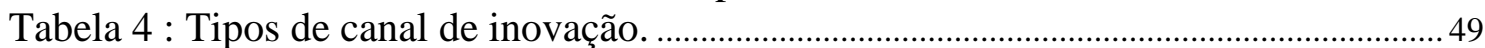

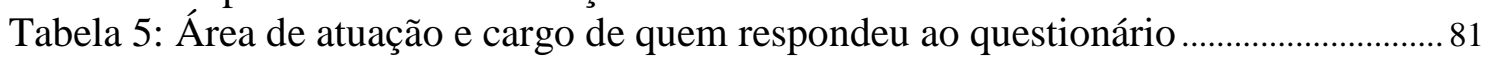

Tabela 6: Número de funcionários e engenheiros por empresa pesquisada .......................... 82

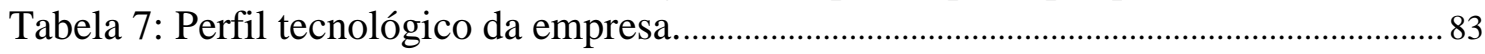

Tabela 8: Composição do capital da empresa e posição de mercado....................................... 83

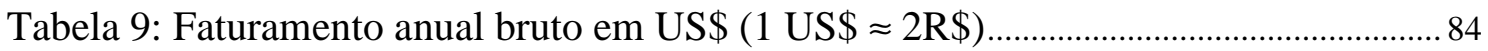

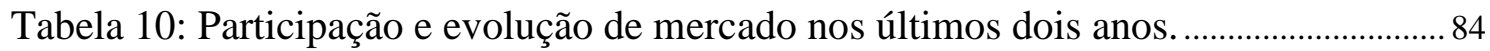

Tabela 11: Exportação sobre faturamento e impacto da abertura de mercado ..................... 85

Tabela 12: Onde se encontra a maior oportunidade de inovação para a empresa ............. 85

Tabela 13: Aspectos importantes no estudo comparativo com produto concorrente ........86

Tabela 14: Fontes de informação mais usadas na análise comparativa com produtos

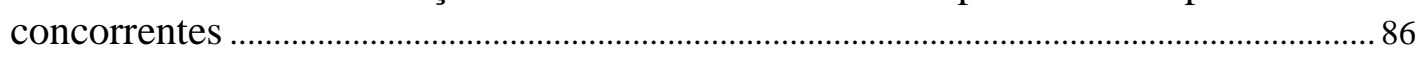

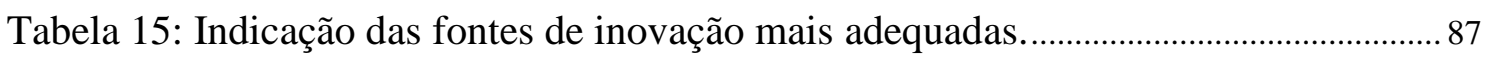

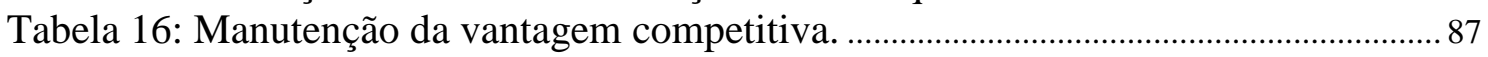

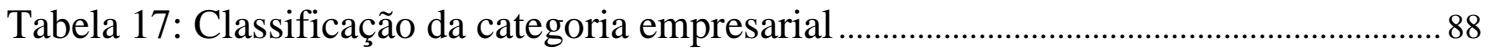

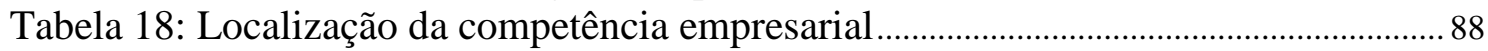

Tabela 19: Processos de desenvolvimento, administração, produtivo e registros ............... 89

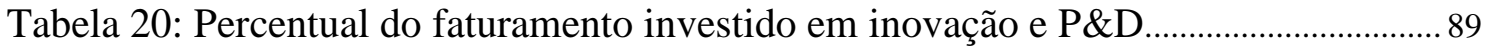

Tabela 21: Veículos indicadores de tendências tecnológicas. ........................................90

Tabela 22: Uso de ferramentas estatísticas de controle de processo....................................... 90

Tabela 23: Métodos de avaliação das expectativas e necessidades do cliente. ...................91

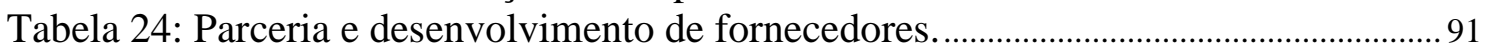

Tabela 25:Fornecimento a estatais e multinacionais e acesso à tecnologia. ..........................92

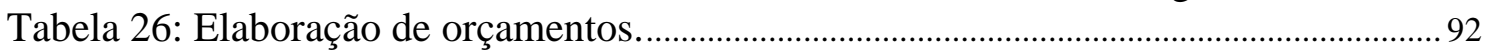

Tabela 27: Prazo para implementação de alterações de ferramental....................................... 93

Tabela 28: Documentação das modificações de processos e/ou produtos..............................93

Tabela 29: Instrumentos de apoio à produção e desenvolvimento.........................................93

Tabela 30: Visão da empresa em relação à inovação tecnológica. ............................................. 94

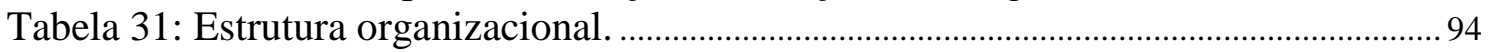

Tabela 32: Criatividade dos colaboradores, capital intelectual e geração de idéias. .........94

Tabela 33: Planejamento da formação do Capital Intelectual.................................................. 95

Tabela 34: Processo e velocidade de comunicação na empresa. ............................................... 95

Tabela 35: Fontes de Inovações Tecnológicas.......................................................................... 97

Tabela 36: Indicadores de Tendências Tecnológicas ..............................................................98

Tabela 37: Distribuiçãa da quantidade de colaboradores e engenheiros .............................. 101

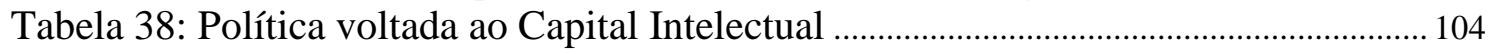

Tabela 39 : Impacto do processo de inovação versus vantagem competitiva. ................... 106

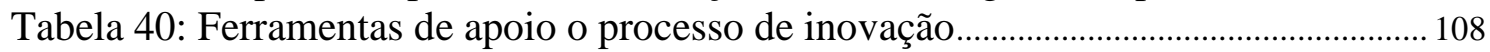

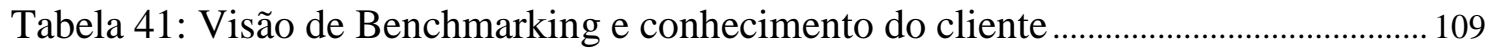

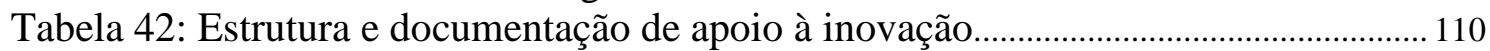

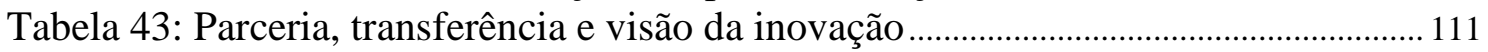


Resumo

O objetivo desta dissertação é avaliar o grau de envolvimento das pequenas e médias empresas do setor da eletroeletrônica no processo de busca da inovação tecnológica

A inovação tecnológica assumiu um caráter estratégico para as empresas, a partir dos anos oitenta. De um lado, a empresa se vê compelida à busca da inovação devido à crescente concorrência inerente à globalização, à crescente exigência do mercado de consumo e à necessidade de manutenção ou aumento de sua fatia de mercado. Por outro lado, a empresa coloca-se em situação mais conservadora devido à incerteza e aos riscos financeiros característicos do processo de inovação.

Existe um elenco bastante amplo de fontes de inovação tecnológica, desde universidades e institutos de pesquisa especializados até o estabelecimento de redes empresariais. Entretanto, o que se observa no cenário industrial do país é o engajamento das grandes corporações multinacionais nesse processo de busca da inovação tecnológica e uso das mais diversas fontes disponíveis. As empresas de pequeno e médio porte ainda mantém-se à margem desse processo de incorporação da inovação, $o$ que amplia o fosso tecnológico entre esses dois blocos industriais.

É inegável a importância social da pequena e média empresa, pois são as responsáveis pela maior parcela do número de empregos, além de responsáveis por grande parte do processo de geração de novas tecnologias. Seu retrocesso tecnológico poderá trazer conseqüências adversas ao capital intelectual e ao desenvolvimento tecnológico do país.

Para a avaliação do perfil inovador das empresas, foi feita uma pesquisa Quantitativa, através de um Levantamento (Survey), com aplicação de questionário estruturado, com uma amostra de vinte e três empresas, sendo vinte e uma delas pertencentes ao segmento eletroeletrônico e duas pertencentes ao segmento da informática.. 
Abstract

The objective of this dissertation is to evaluate the envolvement's degree of small and medium companies from electro / electronic sectors in the process of search the technological innovation.

The technological innovation became strategical characteristic for the companies, from the Eighties. From a side, the company sees itself compelled to search the innovation due to increasing competition inherent to the globalization, the increasing demands of the costumer market and to the necessity of to keep or increase its market share. For the other side, the company is faced in a situation more conservative due the uncertainlly characteristic of the financial risks innerent to the innovation process.

A sufficiently large number of technological innovation's sources exists, from universities and specialized research institutes until the establishment of enterprise networks. However, what it is observed in the industrial scene of the country is the envolvement of wide multinationals corporations in this process of fetching of the technological innovation and use of the most diverse available sources. The small and medium companies still remains at the margin of this incorporation's process of technological innovation, what extends the technological gap between these two industrial kinds of companies.

It's undeniable the social importance of the small and medium companies, because they are responsible for the biggest parcel of the number of jobs, beyond responsible for great part the new technologies generation process. Its technological retard could bring adverse consequences for intellectual capital and for technological development of the country.

For the evaluation of the innovative profile of the companies, a Quantitative research was made, through a Survey, with application of structuralized questionnaire, over a sample of twenty three companies, twenty one of them from the electro/electronic sector and two from the informatic sector . 


\section{Introdução}

Sem dúvida, somos uma nação de empreendedores. Uma pesquisa realizada pela consultoria Ernest \& Young em vinte e um países, emergentes e do primeiro mundo, mostrou que dezesseis por cento da população brasileira monta sua própria empresa. Somos líderes mundiais em iniciativa empreendedora, seguidos pela Coréia do Sul, com catorze por cento da população empreendendo seu próprio negócio, e pelos Estados Unidos, com treze por cento da população apresentando o mesmo perfil empreendedor. Entretanto, este retrato otimista apresenta um reverso sombrio e frustrante: Também somos os líderes mundiais em mortalidade empresarial. No Brasil, trinta e cinco por cento das novas empresas desaparecem antes de um ano de vida. Somente no Estado de São Paulo, onde a iniciativa empreendedora é mais acentuada e especializada, 56\% das novas empresas desaparecem nos primeiros três anos de vida. Este índice situa-se entre $31 \%$ e $38 \%$ no Reino Unido, França, Finlândia, Itália, Noruega e Dinamarca.

As maiores causas dessa mortalidade estão associadas às turbulências de mercado e à carga tributária, considerada excessiva. Entretanto, nada menos que 29\% dos empresários que encerraram suas atividades, apontam a concorrência como causa do fechamento da empresa. Quase um terço das empresas que desaparecem, tem como causa do fechamento, aspectos associados à tecnologia de seu meio ambiente. Porém, é importante salientar que o desempenho da empresa frente à concorrência está associado diretamente à sua própria estrutura de atuação, não dependendo dos seus concorrentes.

Recursos e incentivos existem. Há fundos e programas de incentivo à pesquisa e à inovação tecnológica, mas é fundamental entender-se a fragilidade frente à concorrência como deficiência da política tecnológica e de inovação adotada pela própria empresa.

Mercados em evolução, usuários exigentes e quedas de barreiras comerciais são alguns dos fatores interferentes no cenário industrial atual. O consumidor quer produtos cada vez melhores e a custos cada vez menores, o que implica em necessidade de inovações tecnológicas a freqüências muito maiores que há poucas décadas passadas. A sobrevivência industrial está cada vez mais associada à capacidade inovadora do empresário, tanto na tecnologia de seus produtos quanto em seus processos produtivos. O empreendedorismo associado a práticas profissionais de inovação tecnológica, são o caminho correto para se atingir o fortalecimento da base industrial nacional e o enriquecimento da sociedade. 


\section{Capítulo 1}

\subsection{Objetivo do Trabalho}

Determinar como as pequenas e médias empresas do setor eletro eletrônico, localizadas no estado de São Paulo, executam seu processo de inovação, destinado ao desenvolvimento de novos produtos e processos.

O trabalho desta pesquisa procurará identificar:

a) O grau de conhecimento destas empresas a respeito das principais fontes geradoras de inovação,

b) A importância do Capital Intelectual no processo de busca e incorporação de conhecimento destinado à inovação,

c) $\mathrm{O}$ impacto que este processo de inovação apresenta sobre a vantagem competitiva das empresas,

d) O grau de conhecimento das pequenas e médias empresas quanto às ferramentas de trabalho associadas ao processo de inovação,

e) As práticas gerenciais das pequenas e médias empresas relacionadas ao processo de inovação de produtos e processos.

\subsubsection{Delimitação}

Este trabalho estará delimitado às pequenas e médias empresas localizadas no estado de São Paulo, atuantes no segmento eletro eletrônico, cujas atividades apresentem elevado potencial de inovação tecnológica.

\subsubsection{Definicão de Pequena e Média Empresa.}

A classificação de pequena e média empresa está de acordo com os critérios do SEBRAE. A amostra de empresas a ser incluída no trabalho de levantamento, foi obtida junto à agência do SEBRAE Diadema, a partir dos dados centrais, acessíveis por todas as agências, ou seja, a classificação obtida, bem como a amostra, estão dentro dos padrões nacionais do SEBRAE. 


\section{$\underline{\text { 1.2 Justificativa para este objetivo }}$}

\section{O Aspecto Global}

A queda das barreiras comerciais ao redor do mundo tem-se demonstrado um processo vigoroso e irreversível, cada vez mais distante de um fenômeno cíclico. Esta nova ordem mundial tem colocado as empresas frente aos concorrentes, independente da distância destes. Um pequeno fabricante asiático pode concorrer diretamente com um fabricante de mesmo segmento no Brasil, em igualdade de condições ou até em condições mais vantajosas em função da maior flexibilidade de seus países de origem em aspectos como legislação trabalhista, políticas de importação ou fontes de matéria prima. Cada empresa tem-se colocado frente a frente com um número cada vez maior de concorrentes, cada um deles buscando oferecer produtos mais atrativos ao mercado.

Se existe a pressão competitiva por parte das empresas, existe também a pressão gerada pelo mercado, porque o ambiente social está em constante mudança. Alterações na estrutura social geram a criação de novas necessidades, fazendo com que o consumidor exija cada vez mais, produtos novos e diferenciados; essa diferenciação invariavelmente recai sobre o preço, a qualidade e a adequação dos produtos, aspectos permanentemente monitorados pelo consumidor.

De acordo com Tidd, J. et alii (1997) existe uma forte correlação entre o desempenho de mercado de uma empresa e o seu processo de inovação. Os novos produtos originados pela inovação têm a capacidade de conquistar e manter participações de mercado. A empresa que utiliza o processo sistemático de inovação trabalha com produtos amadurecidos e com posicionamento garantido junto aos usuários, obtendo crescimento em escala de vendas e como conseqüência, podendo proporcionar preços mais competitivos, além dos fatores adicionais referentes a design atualizado, adequação ao consumidor e qualidade.

Dentro dessa mesma estratégia está enquadrada a inovação dos processos. Um produto que tenha passado pelo processo de inovação em seu processo produtivo, não necessariamente poderá ter esta inovação perceptível ao usuário, ao menos imediatamente. A alteração de processo pode estar capacitando a empresa a produzir 
algo de modo único, destacado de sua concorrência, a um custo mais baixo e com maior confiabilidade, sem que a arquitetura do produto tenha passado por alterações. A percepção do consumidor ocorrerá num momento futuro, quando os resultados da inovação se refletirem no preço final e confiabilidade do produto.

Atualmente, a inovação assumiu uma dimensão estratégica para a empresa, tornando-se uma atividade compulsória, e não mais, opcional.

O setor de serviços também apresenta amplas possibilidades para a aplicação de inovações. Setores como, por exemplo, o bancário e o de aviação civil, são exemplos típicos onde os processos de inovação são constantes, mas que, devido ao nosso campo de análise, não farão parte do escopo de análise.

\section{O Distanciamento entre Grandes Empresas e Pequenas/Médias Empresas.}

De acordo com a pesquisadora Eva Stal, integrante da Coordenadoria Executiva de Cooperação Universitária - USP, a revolução tecnológica pela qual estamos passando, torna cada vez mais rápida a obsolescência de produtos e processos, tornando a inovação um aspecto irremediavelmente estratégico. Ainda de acordo com a pesquisadora, grandes empresas sediadas no Brasil, estão fortalecendo o intercâmbio de conhecimento com universidades brasileiras. Porém, os dados da Coordenadoria Executiva de Cooperação Universitária indicam que essencialmente as subsidiárias das grandes empresas multinacionais (Siemens, Pirelli, Mercedes-Benz, entre outras) apresentam esse perfil de busca de novas tecnologias junto ao ambiente acadêmico científico.

Por outro lado, é crescente o fenômeno denominado empresas-rede, onde um grupo de empresas de mesmo segmento, ou concorrentes, se unem a fim de desenvolver inovações de modo mais ágil e com menor custo. De acordo com Castells, M. (1999) as redes tem sido lideradas ou constituídas por grupos multinacionais, o que aumenta a concentração oligopolista, fortalecendo a base da economia globalizada. E são exatamente as empresas rede as que têm obtido maior sucesso dentro da nova ordem econômica mundial. Este aspecto se constitui num enorme desafio às pequenas e médias empresas, de antemão, desfavorecidas em termos estruturais, quando confrontadas com as multinacionais. De acordo com Muniz, S. (2000) existem exemplos de redes 
formadas por pequenas e médias empresas em outros países, como é o caso de Hong Kong, onde as pequenas e médias empresas, estruturadas em rede, formam a base exportadora do país.

É inegável que apresentamos pré-requisitos para o fortalecimento da inovação tecnológica dentro de nosso ambiente nacional:

- O primeiro computador brasileiro surgiu na Escola Politécnica da USP, criando a primeira geração de recursos humanos que utilizaram a informática.

- A capacitação brasileira em fibras óticas surgiu de um convênio entre Telebrás e o Instituto de Física da Unicamp.

- O Brasil tem uma indústria aeronáutica que vence concorrências internacionais, fruto da interação entre a Embraer e o Instituto Tecnológico da Aeronáutica - ITA.

- A UNESP, campus Botucatu, em parceria com a Escola Superior de Agricultura Luís de Queiroz - USP, desenvolveu super laranjeiras através da biotecnologia, proporcionando $20 \%$ de aumento de produtividade nos pomares da empresa Citrovita Agroindustrial, integrante do Grupo Votorantim. Essa tecnologia era disponível somente na Espanha e Israel.

Se por um lado, isto representa o fortalecimento da pesquisa nacional e da formação acadêmica, por outro lado pode representar um aumento no fosso que separa as grandes corporações (nacionais e multinacionais) e as pequenas e médias empresas nacionais no que se refere à inovação tecnológica. E fato que toda esta bagagem tecnológica tem sido subutilizada. De acordo com Roberto Sbragia da Associação Nacional de Pesquisa e Desenvolvimento de Empresas Industriais - ANPEI, há um grande esforço para investimento em equipamentos e laboratórios, porém, por parte das grandes empresas.

De acordo com o engenheiro Sílvio Manrici, diretor da Fundação de Apoio Institucional ao Desenvolvimento Científico e Tecnológico da UFSCar, o acesso das empresas às pesquisas desenvolvidas nas universidades ainda está aquém do ideal.

Confirmando esta opinião, José Mindlin, presidente de uma das Comissões do Conselho Nacional de Ciência e Tecnologia, afirma que existe no país uma grande demanda de tecnologia por parte das empresas, as quais desconhecem essa oferta tecnológica que pode ser obtida a baixo custo. 
Ainda de acordo com José Mindlin, os grandes entraves ao acesso das pequenas e médias empresas à inovação tecnológica, que conduz à competitividade, são:

- O aspecto cultural dessas empresas, que ainda não identificam de modo claro, a inovação como um dado estratégico.

- O imediatismo de resultados, fazendo com que muitas vezes a empresa prefira comprar tecnologia pronta, a um custo mais elevado, ao invés de trabalhar em parceria com institutos de pesquisa, cujo fornecimento de tecnologia apresenta menor custo, porém, sem a priorização dos prazos.

- A preocupação com a sobrevivência, fazendo com que a pequena e média empresa concentre-se apenas no dia a dia, sem planejar sua atuação futura.

Desse modo, surge um cenário pouco alentador para a pequena e média empresa. Justamente as grandes empresas, que contam com maior número de técnicos, recursos financeiros, laboratórios e centros de desenvolvimento são as que mais se preocupam com a busca de novas tecnologias, essencialmente junto às universidades. 


\section{Capítulo 2 - Revisão Bibliográfica}

\section{1 A Inovacão: Definicão, tipos e seu aspecto estratégico.}

Neste capítulo será feita uma revisão bibliográfica referente à inovação e seus vários aspectos, enfocando-se sua definição, modalidades, estrutura e a análise deste processo sob a ótica de uma ferramenta gerenciável. Será feita também uma abordagem referente ao processo de inovação no Brasil.

\subsubsection{A inovacão e o estímulo gerador.}

Começaremos este capítulo pela definição detalhada do que é inovação. É possível que haja uma tendência em se imaginar a inovação como uma simples novidade ou, imaginar a inovação como uma "invenção" pura e simples.

\section{O que é inovação?}

Inovação é algo abrangente, que vai além da simples novidade ou invenção. Entre invenção e inovação existe toda uma sequiência de atividades complexas. De acordo com Freeman, C. (1982), “a inovação industrial inclui o projeto técnico, manufatura, gerenciamento das atividades comerciais envolvidas na comercialização de um produto novo (ou melhorado) ou o primeiro uso comercial de um novo (ou melhorado) processo ou equipamento".

Podemos dizer que a inovação compreende a disponibilização de uma invenção ao consumo em larga escala ${ }^{1}$. Sendo assim, a sua viabilização está muito mais associada ao empreendedor que ao inventor propriamente dito, mesmo apesar do invento (ou a

\footnotetext{
${ }^{1}$ Um dos casos mais ilustrativos desse aspecto é o da máquina de costura, inventada por Elias Howe em 1846. Apesar do imenso mercado potencial para esse produto, à época, seu invento permaneceu estagnado, até ser apropriado por Isaac Singer, que anteviu o mercado para esse produto, concebeu o processo produtivo e todo a cadeia de comercialização. Hoje em dia, a máquina de costura é associada a Isaac Singer, o inovador, sendo que poucos sabem quem é Elias Howe, seu verdadeiro inventor. Outro exemplo é o do aspirador de pó, idealizado por J. Murray Spengler, que o denominou "succionador elétrico", não tendo, porém, nenhuma idéia para sua aplicação. Foi W. H. Hoover quem visualizou a aplicação desse invento ao segmento de eletrodomésticos, atribuindo a denominação "aspirador de pó".
} 
idéia) ser o seu ponto de partida. De acordo com Drucker, P. (1985), a inovação é a ferramenta de trabalho dos empreendedores, o meio através do qual eles usam as mudanças como oportunidades para novos negócios ou novos serviços.

É importante também se distinguir a inovação organizacional da inovação tecnológica, de naturezas bastante diversas. De acordo com Muniz, S. (2000) a inovação organizacional tem como objetivo, a busca do aprimoramento organizacional de uma empresa. Nesse contexto incluímos a automação eletrônica através da conexão entre máquinas, unidades de produção, interligação empresas/fornecedores e softwares de gestão empresarial.

A inovação tecnológica, objeto deste estudo, está associada ao trabalho de seleção, busca e desenvolvimento tecnológico, o qual não pode ser substituído pela automação eletrônica.

\subsubsection{O estímulo gerador.}

Para que o processo de inovação se desenvolva dentro da empresa, é fundamental que esta esteja capacitada a detectar os sinais externos de mudança provenientes do mercado ou da evolução tecnológica.

Esses sinais podem ser decorrentes de novas oportunidades tecnológicas, podem ser resultantes de mudanças nas exigências do mercado consumidor, podem ser resultantes de pressão da legislação ou pressão dos concorrentes.

Toda essa variedade de sinais pode ser agrupada em duas categorias de estímulos, denominados Estímulo Tecnológico e Estímulo de Mercado, conforme segue:

Estímulo Tecnológico: É a situação em a própria evolução tecnológica cria pressões ou oportunidades para a inovação. As oportunidades decorrentes do estímulo tecnológico podem ou não ser programadas. Como exemplos de inovações não programadas, podemos citar o caso do forno de micro ondas, cujo potencial de aplicação aos eletrodomésticos foi descoberto por acaso; outro exemplo conhecido é o do produto Teflon de propriedade da DuPont, cuja descoberta deu-se por acaso, decorrente da falha de armazenamento de produtos químicos em cilindros metálicos. Coube às empresas dos respectivos segmentos visualizarem e entenderem a aplicação inovadora para cada produto. Como o estímulo tecnológico é permanente, temos inúmeros casos de inovações programadas, que podem fazer com que as empresas mudem o curso ou 
direção de seus projetos repentinamente. Um exemplo é o caso dos novos softwares de reconhecimento de voz (IBM e Philips) lançados recentemente, que colocam os teclados de computadores em percurso de final de linha. As empresas do setor de desenvolvimento de equipamentos de informática, com maior potencial de inovação, terão que desviar os esforços tecnológicos eventualmente aplicados sobre a tecnologia de teclados, para outros produtos. Certamente não valerá a pena investir em inovações sobre produtos com horizonte final já programado.

Estímulo de mercado: É a situação mais geral e comum, em que as oportunidades de inovações surgem por pressão da concorrência, da legislação ou dos próprios consumidores. É no mercado, ou no meio ambiente da empresa, que se encontram os aspectos fundamentais da estratégia competitiva, que agem diretamente sobre o processo de inovação. Conforme Porter, M.E. (1998), a estratégia competitiva de uma empresa está associada diretamente ao meio ambiente (mercado) onde situa-se esta empresa. Dentro desse contexto, Porter, M.E. (1998) define as cinco forças competitivas que atuam sobre a empresa, conforme a figura a seguir:

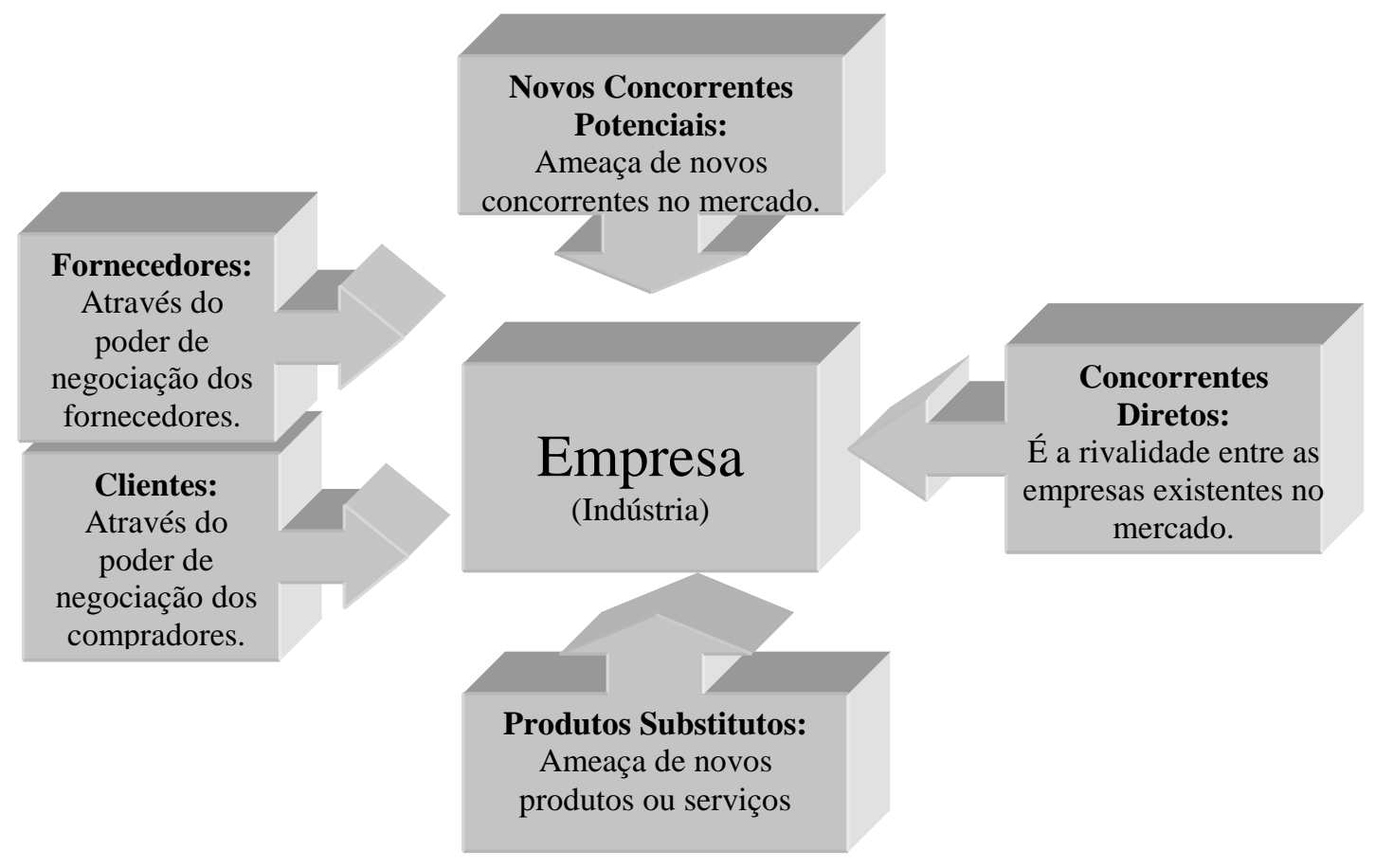

Figura 1: As cinco forças competitivas que interferem na empresa.

Fonte: Porter, M.E.: Estratégia Competitiva - Técnicas para Análise de Indústrias e da Concorrência. Campus, Rio de Janeiro, 1998. 
Um exemplo claro das inovações geradas por pressão da concorrência é o segmento automobilístico, onde automóveis de modelos básicos são oferecidos com acessórios normais de fábrica até pouco tempo atrás encontrados apenas em veículos de luxo e como acessórios opcionais. Exemplo disso é o "air bag", até recentemente um acessório opcional em veículos de luxo, na maioria importados, e que hoje é encontrado em veículos básicos como acessório "de fábrica". Quando se trata de estímulos de mercado, a inovação assume um papel mais voltado à sobrevivência da empresa, visto que na maioria das vezes, o processo de inovação torna-se compulsório. Não há opção, ou a empresa aplica a inovação ou será segregada do mercado, pelos concorrentes, pela legislação ou pelos consumidores diretamente.

\subsubsection{A vantagem competitiva e a inovacão}

A vantagem competitiva de uma empresa pode estar associada diretamente ao seu porte ou faturamento. Entretanto a manutenção e aumento dessa vantagem competitiva estão associados diretamente à mobilização de conhecimentos, habilidades tecnológicas e experiências voltadas ao desenvolvimento de novos produtos, novos processos e novos serviços, ou seja, a manutenção e aumento da vantagem competitiva estão diretamente associados ao processo de inovação. Neste parágrafo serão discutidos os tipos de inovação mais comuns, as evidências que vinculam a vantagem competitiva com a inovação, bem como os riscos envolvidos.

\subsubsection{Tipos e dimensões da inovacão}

Conforme Freeman C. e Perez, C. (1988), existem três tipos de inovações tecnológicas:

- A inovação incremental: Ocorre no cotidiano de qualquer atividade industrial ou de serviços, com velocidade variando em função do país e da empresa.

- A inovação radical: É descontinua, e resulta da P\&D em empresas, universidades e laboratórios.

- A inovação de sistemas tecnológicos: É na verdade um conjunto de inovações inter-relacionadas técnicas e economicamente.

De acordo com Tidd, J. et alli (1997), a inovação apresenta duas dimensões importantes:

- O que mudou (produto ou processo);

- O grau da mudança aplicada, ou seja, radical ou incremental. 
Ambas dimensões geram o que é denominado o grau da inovação percebida, sob a ótica do cliente ou usuário.

Deve-se lembrar que para a empresa, é fundamental a visualização da inovação por parte do cliente. O gráfico abaixo nos indica de maneira genérica, como a percepção da inovação ocorre sob a ótica do cliente:

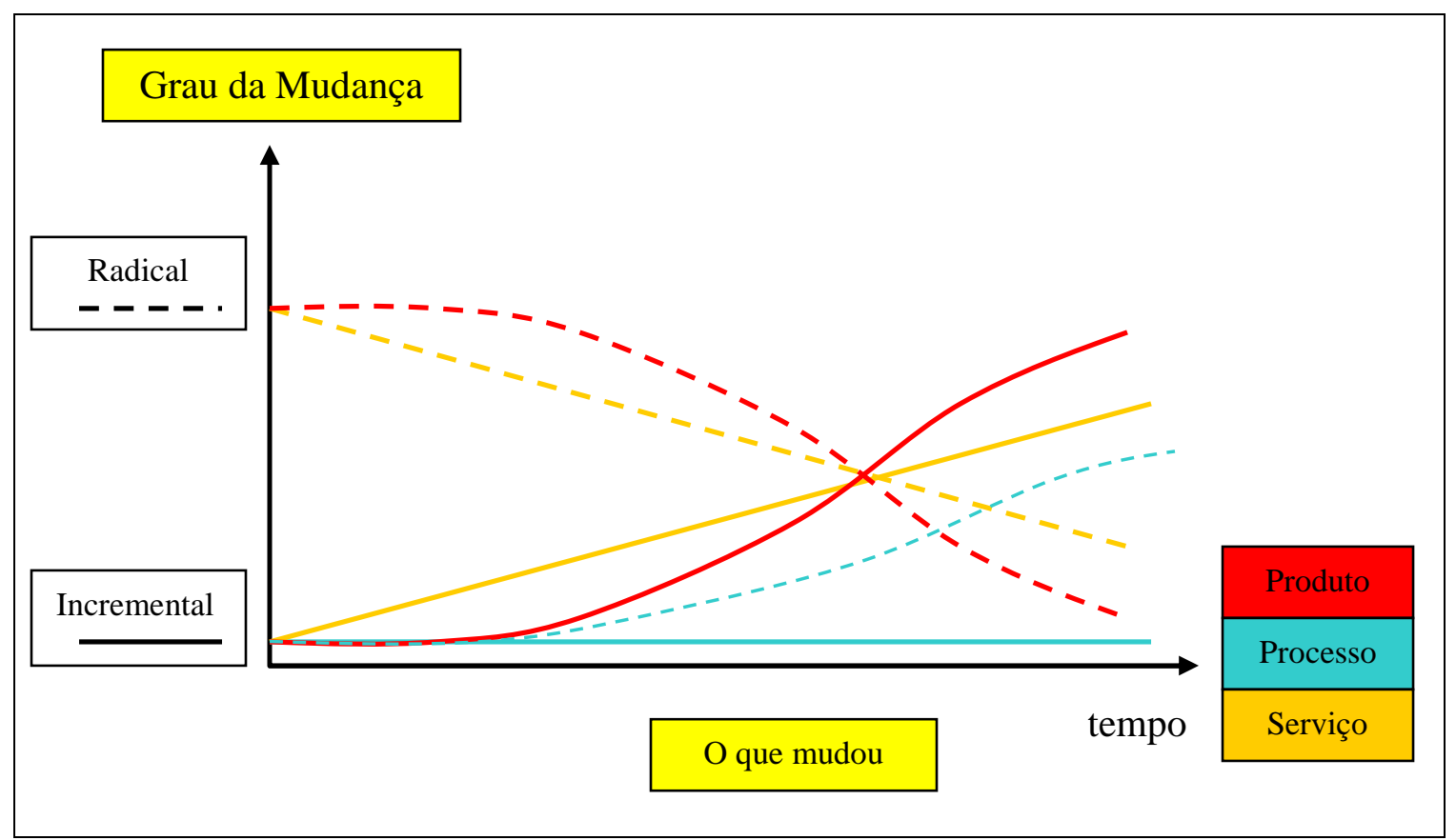

Figura 2: Grau de percepção da inovação sob a ótica do cliente.

Fonte: Tidd, J. et alii: Managing Innovation, Integrating Technological, Market and Organizational Change. John Wiley \& Sons, London, 1997. Dados acrescentados por J.R.Tálamo.

Vale ressaltar ainda, os conceitos de produto e de componente. De acordo com Henderson, R. e Clark, K. (1990), tanto em produtos quanto em serviços, é importante definir-se produto isolado, componente de uma família de produtos, e arquitetura de produtos. Um mesmo produto pode assumir a forma de um componente de uma família produtos ou pode assumir a forma de um produto isolado, conferindo a cada situação, diferentes graus de inovação tecnológica ${ }^{2}$. Desse modo, o mesmo produto pode estar passando por uma mudança radical, quando sob a forma de produto isolado, ou estar gerando uma mudança incremental, quando sob a forma de componente de uma arquitetura de produtos.

${ }^{2}$ Como exemplo, podemos citar o caso de um "disco rígido" que passe por uma alteração tecnológica acentuada. Como produto isolado, poderemos dizer que a inovação é radical. Entretanto, se este disco rígido faz parte de uma arquitetura de produtos, irá conferir a esta família uma alteração incremental. 
Ainda sob esse aspecto, referente a mudanças radicais ou incrementais, vale lembrar que é comum ser dada uma grande ênfase às mudanças radicais, objetivando-se saltos tecnológicos, em detrimento de mudanças incrementais, ou seja, de menor porte. Entretanto, de acordo com Hollander, S. (1965), os ganhos cumulativos obtidos através de mudanças ou inovações graduais, muitas vezes é maior do que os ganhos obtidos com as mudanças radicais. São exatamente esses ganhos, os geradores da vantagem competitiva da empresa.

\subsubsection{A vantagem competitiva gerada pela inovação}

Conforme já comentamos na parte introdutória, a inovação tem uma forte correlação com o bom desempenho de mercado. Sua aplicação na geração de novos produtos possibilita à empresa a ampliação e manutenção de maiores fatias de mercado, enquanto no caso de produtos já existentes, a inovação aplicada de modo incremental, pode gerar crescimento nas vendas, além de possibilitar adequação ao cliente e melhoria contínua da qualidade.

A figura 3 a seguir indica o resultado de uma pesquisa efetuada por Reichfeld, E.F. (1996) sobre mais de 100 empresas voltadas à tecnologia intensiva, onde é estabelecida uma relação entre a posição da empresa no mercado e o percentual de suas vendas correspondentes a produtos lançados nos últimos 5 anos:

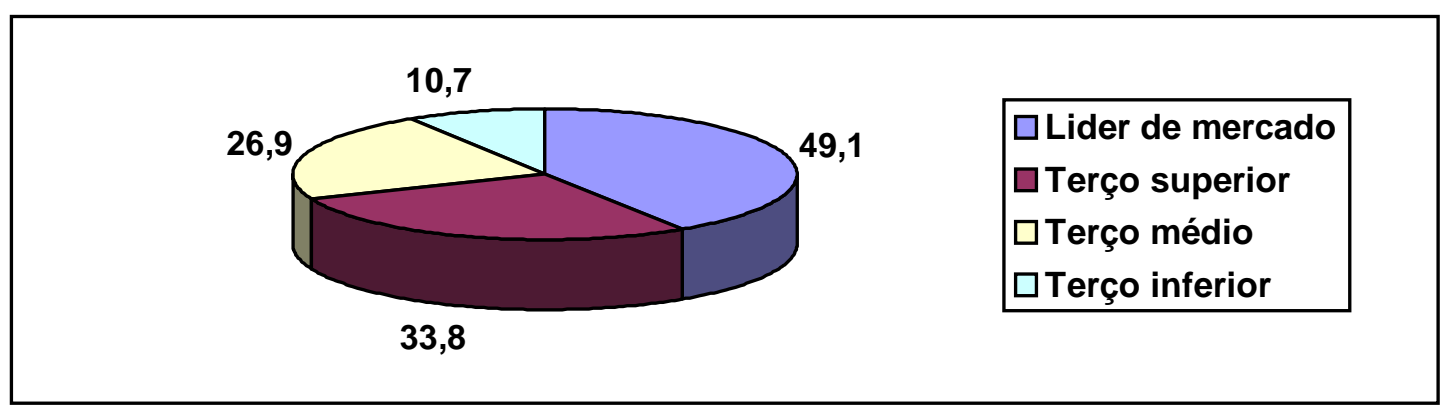

Figura 3: Posição de mercado e percentual de vendas referentes a novos produtos.

Fonte: Terra, J. C. C.: Gestão do conhecimento: Aspectos conceituais e estudo exploratório sobre práticas de empresas brasileiras, Tese de doutorado, EPUSP, 1999

O ambiente está em permanente mudança, quer pelos hábitos dos consumidores que se alteram, quer pelas mudanças de padrão sócio econômico, pela legislação ou mesmo pela competição. Isto tem feito com que o ciclo de vida dos produtos venha sofrendo 
redução constante ao longo dos anos. A renovação de produtos eletro eletrônicos é feita em poucos meses; a renovação de produtos de informática tem sido mais veloz ainda.

O mercado automobilístico, que gerava mudanças a cada década, hoje tem feito renovações tecnológicas em motores e câmbios, em prazos inferiores a três anos. Isto é abordado por Walsh, V. (1992), que destaca a importância crescente da capacidade de renovação que a indústria deve ter. Isto se reflete também nos processos. Não basta a indústria apenas renovar produtos; ela tem que produzir seus produtos com velocidade cada vez maior, para chegar ao mercado antes de seu concorrente, produzir de forma cada vez mais econômica e de modo melhor que seus concorrentes. A inovação de processos tem sido cada vez mais vista como fonte de vantagens adicionais bastante poderosa. De acordo com Tidd, J. et alii (1997), a vantagem competitiva obtida pela indústria japonesa nas áreas de automobilística, motociclismo, construção naval e produtos eletro eletrônicos, deu-se fundamentalmente através de inovações nos processos produtivos.

Quando a empresa incorpora o processo de inovação à sua cultura, ela obtém a capacidade de selecionar a vantagem competitiva desejada, o que em si já é um ganho adicional sobre os concorrentes, pois a empresa passa a contar com discernimento e autodeterminação em seu processo de evolução; ou seja, a empresa não apenas se insere no processo de inovação como também traça seu próprio caminho na busca das vantagens competitivas. A tabela abaixo indica o tipo de vantagem competitiva a ser obtida, em função do tipo de inovação em uso:

Tabela 1 :Vantagem competitiva em função do tipo de inovação utilizada.

\begin{tabular}{|l|l|}
\hline \multicolumn{1}{|c|}{ Tipo de inovação } & \multicolumn{1}{|c|}{ Vantagem competitiva } \\
\hline Novidade & Destaque frente aos concorrentes. \\
\hline Competência & Capacidade de ditar as regras do jogo competitivo \\
\hline Complexidade & Introdução de barreiras de conhecimento sobre os concorrentes \\
\hline Robustez do projeto & Extensão do ciclo de vida do produto e redução dos custos totais \\
\hline Inovação contínua & Melhoria contínua da relação custo/desempenho \\
\hline
\end{tabular}

Fonte: Tidd, J. et alii: Managing Innovation, Integrating Technological, Market and Organizational Change. John Wiley \& Sons, London, 1997. 


\subsubsection{Riscos inerentes}

Apesar da estreita relação entre inovação e vantagem competitiva, deve-se lembrar que o processo de inovação coloca a empresa à frente de uma série de fatores incertos e de controle difícil. Toda inovação inclui um risco inevitável. A história tem mostrado vários casos em que a inovação resultou em erros ${ }^{3}$. Entretanto, apesar da incerteza envolvida, o investimento na inovação deixou de ser uma opção, para tornar-se uma necessidade de sobrevivência nos dias de hoje. Enquanto a inovação pode diferenciar a empresa que a aplica, pode também aniquilar a empresa concorrente. Conforme Muniz S. (2000), a inovação tecnológica tem efeitos invasivos, pois interfere nas atividades já constituídas da empresa, além de gerar novos produtos, serviços ou segmentos, ou seja, altera a dinâmica da empresa.

De acordo com estudos efetuados por Utterback, J. (1994), quase 40\% das empresas que figuravam na lista das 500 maiores da revista Fortune em 1987, desapareceram, ao mesmo tempo em que quase $60 \%$ das empresas que figuravam na mesma lista em 1970, foram adquiridas por outras ou também desapareceram. Das 12 maiores empresas americanas em 1900, restou apenas uma: a General Electric. De acordo com suas análises, essas empresas desapareceram principalmente devido a mudanças tecnológicas. Um exemplo brasileiro foi o grupo IRFM - Industriais Reunidas Francisco Matarazzo, que integrava a lista Forbes das 100 maiores empresas do mundo na década de 20, mas desapareceu do mercado devido à não inovação de sua linha de produtos. Empresas gigantes como IBM, Xerox ou GM, estão vulneráveis a alterações tecnológicas repentinas, a não ser que apresentem uma base tecnológica sólida que faça com que elas acompanhem as mudanças. Mesmo as empresas pequenas, tradicionalmente mais ágeis, estão vulneráveis ao desaparecimento devido a alterações tecnológicas radicais, que alterem as regras técnicas e econômicas do mercado. Esse estudo chegou a duas conclusões:

\footnotetext{
${ }^{3}$ Em 1952, a Ford lançou um veículo desenvolvido para concorrer com os modelos de médio porte produzidos pela Chrysler e GM, denominado Ford E. Após o lançamento, cada veículo consumiu em média, US\$10.000,00 (o dobro do preço do carro) para rodar. Inclusive, o veículo falhou durante uma propaganda ao vivo pela TV. Em 1972, um consórcio franco britânico lançava o supersônico Concorde, com a expectativa de fazer uma revolução na aviação comercial. Apesar da velocidade de $2150 \mathrm{~km} / \mathrm{h}$ (contra os $927 \mathrm{~km} / \mathrm{h}$ do Boeing 747) e da suntuosidade, hoje restam apenas 7 unidades em operação. Transporta 100 passageiros (contra os mais de 400 dos grandes aviões atuais), a um preço proibitivo. Seu projeto está irremediavelmente condenado, e os recursos obtidos não pagaram os altos custos. A cópia soviética, o Tupolev TU 144, foi aposentada nos anos 80 por motivos técnicos e comerciais.
} 
- A maioria das inovações radicais, que alteram as ordens vigentes, é originada por empresas novas e alheias ao segmento das indústrias que sofrem o impacto inovador.

- Poucas empresas sobrevivem às alterações tecnológicas radicais.

Portanto, a inovação apresenta fundamentalmente dois riscos:

- A incerteza da empresa quanto ao sucesso.

- O risco de desaparecimento da empresa frente à inovação alheia.

Junto a estes fatos, existe ainda o aspecto gerado pela financeirização das empresas, conforme abordado por Muniz, S. (2000). O padrão atual de mercado exige que as empresas apresentem ganhos compatíveis com os ganhos financeiros de mercado. Isto pode levar a empresa ao atropelo na busca da inovação, devido à velocidade que deve imprimir aos seus ganhos, podendo gerar o retardo na absorção de tecnologia, fatal aos negócios, ou a absorção de tecnologia inadequada.

Frente a esses fatos, o dilema maior para as empresas deixa de ser a dúvida quanto a inovar ou não, para tornar-se "como inovar com sucesso". Cabe à empresa administrar o processo de inovação da forma mais eficiente possível, de modo a minimizar a incerteza e os riscos.

A figura abaixo relaciona o nível de incerteza com o tipo de resposta aos estímulos ambientais, de acordo com o ambiente no qual a empresa está inserida. O tipo de resposta da empresa frente aos desafios, está ligado diretamente ao ambiente ao qual ela pertence. 
Necessidade de novas respostas

\begin{tabular}{|c|c|}
\hline $\begin{array}{l}\text { Ambiente calmo com estruturas } \\
\text { industriais estáveis, onde novas } \\
\text { empresas podem explorar a } \\
\text { mudança tecnológica, de modo a } \\
\text { reescrever as regras do jogo. } \\
\text { Como exemplos podemos citar as } \\
\text { empresas de seguros. }\end{array}$ & $\begin{array}{l}\text { Ambiente de mudanças rápidas, } \\
\text { tais como as áreas de } \\
\text { biotecnologia ou tecnologia da } \\
\text { informação, onde a estrutura } \\
\text { industrial está em constante } \\
\text { modificação. A inovação é } \\
\text { fundamental à sobrevivência. } \\
\text { Novas oportunidades surgem } \\
\text { constantemente }\end{array}$ \\
\hline aixa incerteza & $\rightarrow \quad$ Alta incerte \\
\hline $\begin{array}{l}\text { Ambiente calmo onde a } \\
\text { necessidade de inovações pode } \\
\text { não estar evidente. As condições } \\
\text { ambientais e a estrutura industrial } \\
\text { estáveis podem dar um ar de falsa } \\
\text { segurança, até que novas } \\
\text { tecnologias ou novos concorrentes } \\
\text { introduzam transformações no } \\
\text { mercado. O maior risco para as } \\
\text { empresas estabelecidas é que a } \\
\text { resposta às mudanças pode ser um } \\
\text { pouco tardia. }\end{array}$ & $\begin{array}{l}\text { Ambiente de mudanças rápidas, } \\
\text { onde as empresas integrantes } \\
\text { continuam dominando, através da } \\
\text { aplicação de respostas adequadas. } \\
\text { O risco de a empresa ser } \\
\text { surpreendida é menor. Como } \\
\text { exemplo, podemos citar o mercado } \\
\text { automobilístico ou o mercado de } \\
\text { computação de grande porte. }\end{array}$ \\
\hline
\end{tabular}

Velhas respostas, porém ainda apropriadas

\section{Figura 4: A incerteza do meio ambiente da empresa e a resposta da empresa}

Fonte: Tidd, J. et alii: Managing Innovation, Integrating Technological, Market and Organizational Change. John Wiley \& Sons, London, 1997.

\section{$\underline{2.2}$ A vida do produto e a transformacão da inovacão}

Todo produto ou processo apresenta seu característico ciclo de vida. Através desse ciclo de vida que se inicia no projeto, o produto (ou processo) passa por transformações, às vezes até radicais, que caracterizarão diferentes tipos de inovação.

\subsubsection{O ciclo de vida do produto e a freqüência da inovação}

A representação do ciclo de vida de um produto é feita através de duas curvas típicas:

- a "curva da banheira", que recebe essa denominação devido à sua forma mais freqüente, cujo enfoque é a vida do produto sob o ponto de vista técnico,

- a curva do ciclo de vida econômica do produto, cujo enfoque é econômico. 
De acordo com Bérgamo Filho, V. (1997) cada uma das fases da vida "técnica" do produto são caracterizadas por tipos específicos de falhas, como segue:

1. Mortalidade Infantil, causada por:

- Projeto e instalação inadequados;

- Falhas na revisão de projeto;

- Falhas na definição de inspeção;

- Processos de manufatura inadequados;

- Especificações inadequadas de manuseio e transporte;

- Falhas na especificação de matéria prima;

- Falhas na especificação de componentes;

2. Vida útil, caracterizada por:

- Fator de segurança insuficiente;

- Cargas excessivas (em termos de peso, corrente elétrica, esforço físico, etc.);

- Falhas de inspeção;

- Uso inadequado por parte do cliente/usuário;

- Falhas de mão de obra no processo produtivo;

- Falhas não explicadas.

3. Velhice:

- Degradação;

- Fadiga;

- Falha de manutenção.

Cada uma das fases da vida técnica do produto, caracterizada pela "curva da banheira", pode ser observada na Figura 4 a seguir: 


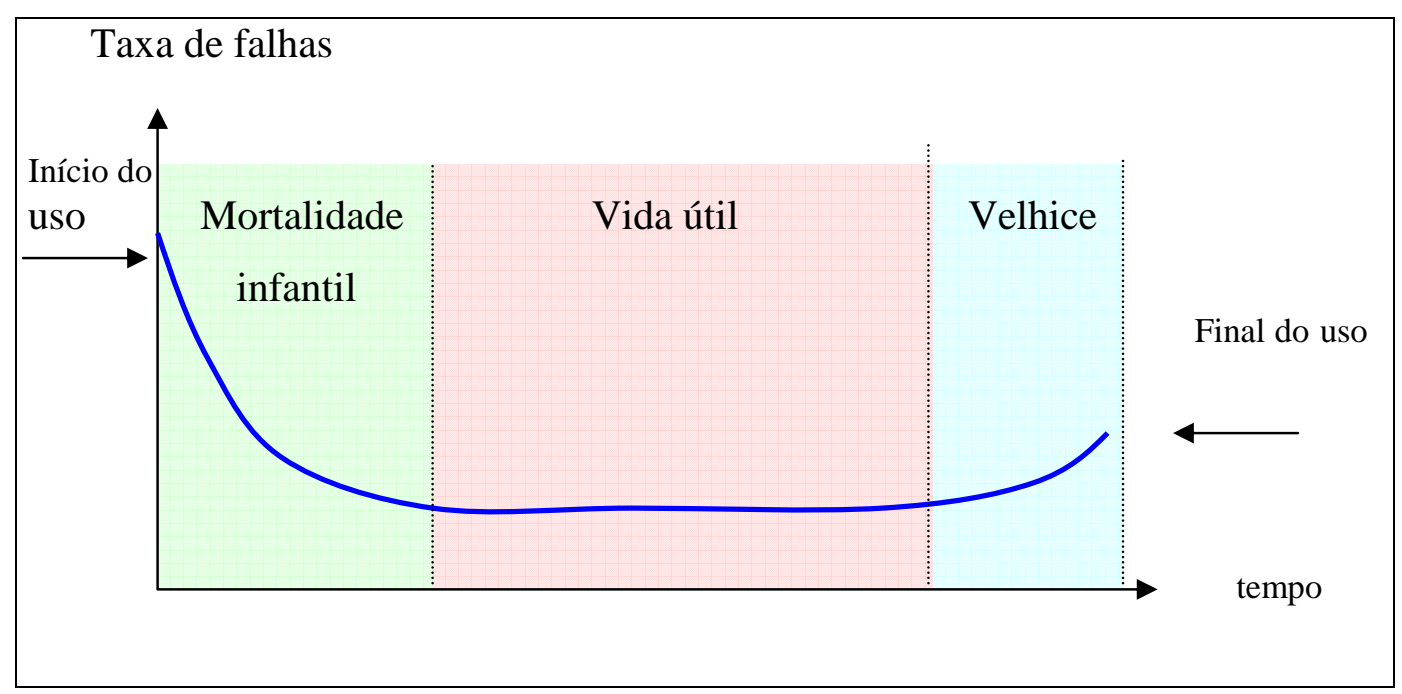

Figura 5: Curva da banheira

De acordo com Valeriano, D. (1998), o ciclo de vida de um produto, sob o aspecto comercial, também segue um padrão definido. O ciclo inicial, denominado Difusão, compreende a introdução e o crescimento das vendas do produto. Em seguida há maturidade, com duração entre meses e alguns anos, e finalmente o declínio do produto, causado pela obsolescência e desinteresse do mercado, entre outros motivos. A figura 5, abaixo, ilustra a curva típica do ciclo de vida econômica.

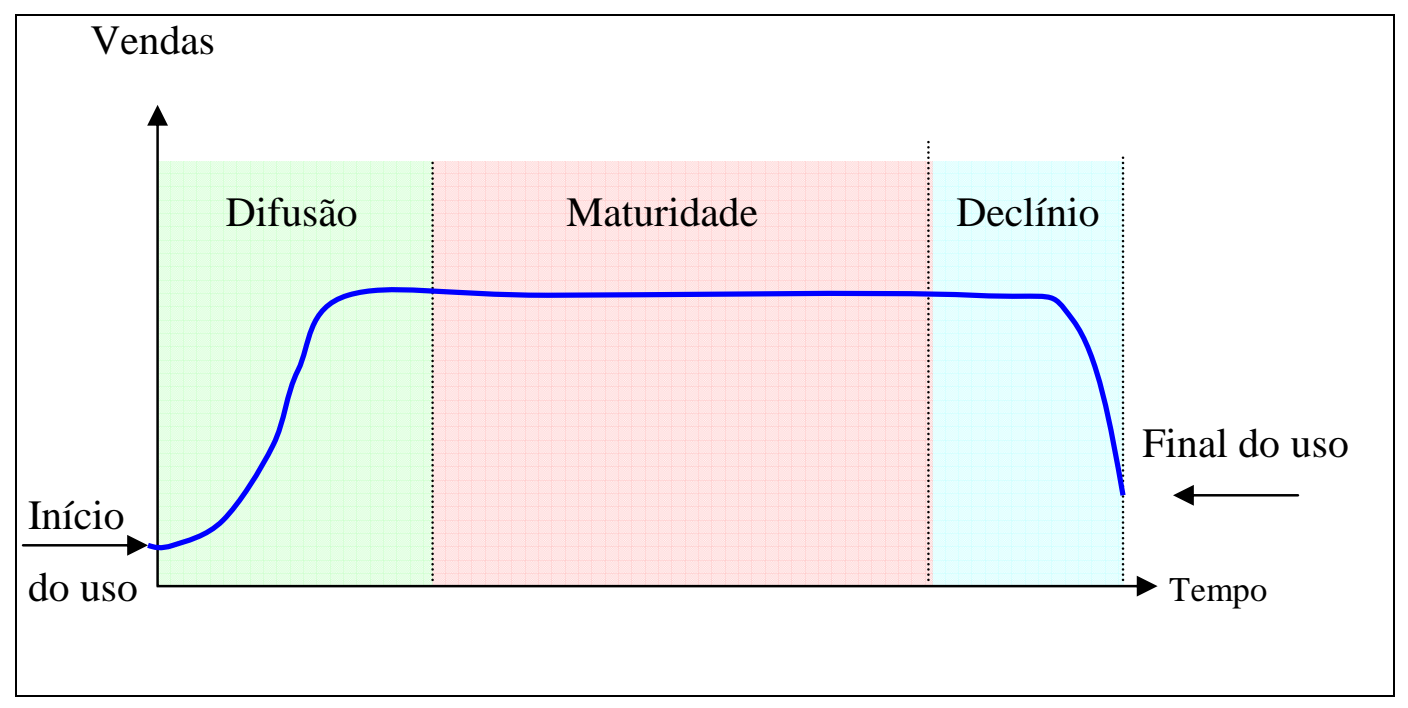

Figura 6: Ciclo de vida econômica do produto.

Podemos observar a correspondência direta entre as fases de ambos os gráficos. 


\subsubsection{A transformacão da inovação.}

Cada diferente fase da vida do produto irá implicar em ênfases diferentes no processo de inovação.

- A inovação nas fases da mortalidade infantil e difusão comercial do produto:

A fase inicial da vida de um produto é caracterizada por falhas precoces e crescimento de vendas. Nesta fase, as taxas de falhas e de vendas são acentuadas, a primeira apresentando tendência decrescente e a segunda, crescente. O decréscimo da taxa de falhas e o crescimento das vendas serão influenciados diretamente pelas inovações introduzidas. Nesta etapa, as inovações devem ser muito variadas e caracterizadas pela rapidez e alta frequiência de aplicação. A finalidade da inovação nesta fase (sob a ótica técnica e comercial) é a correção das falhas residuais de projeto para preservação da imagem, redução dos custos de garantia e manutenção/aumento da fatia de mercado.

- A inovação na fase da vida útil ou maturidade do produto:

A vida útil é caracterizada pela taxa de falhas constante e falhas ocorrendo de modo aleatório. Os problemas iniciais referentes ao projeto já foram sanados. O produto já está em sua fase de concepção estável, necessitando de mudanças incrementais. Comercialmente, o produto está com as vendas estáveis e uma parcela de mercado já estabelecida. De acordo com Sahal, D. (1981) nesta fase é fundamental que as inovações sejam voltadas à inovação do processo. A empresa deve enfatizar a fabricação do produto da forma mais ágil, eficiente e ao menor custo possível.

É nesta fase que a empresa deve reanalisar a arquitetura do produto, avaliando o potencial de futuras gerações de famílias de produtos.

- A inovação na fase da velhice e declínio econômico de um produto:

$\mathrm{Na}$ fase final da vida de um produto, este já está maturado e estável, com praticamente todas as alterações esperadas pelo usuário já implantadas e o processo em sua fase de maturidade, as inovações são caracterizadas pela concentração na redução de custos.

É fundamental que a empresa saiba identificar o estágio em que se encontra a vida do produto e saiba também reconhecer o potencial do estágio atual do produto, bem como o potencial de futuras famílias de produtos. 


\subsection{Como se desenvolve o processo de inovacão dentro da empresa}

É possível estabelecer uma lista de atividades para sistematizar-se o processo da inovação.

Vários modelos de auditoria da inovação foram desenvolvidos a fim de avaliar-se o desempenho na gestão de uma inovação. Alguns modelos são formados por uma lista de verificações, outros são formados por estruturas, outros de operações e sub-processos particulares. O mapeamento genérico do processo está indicado a seguir:
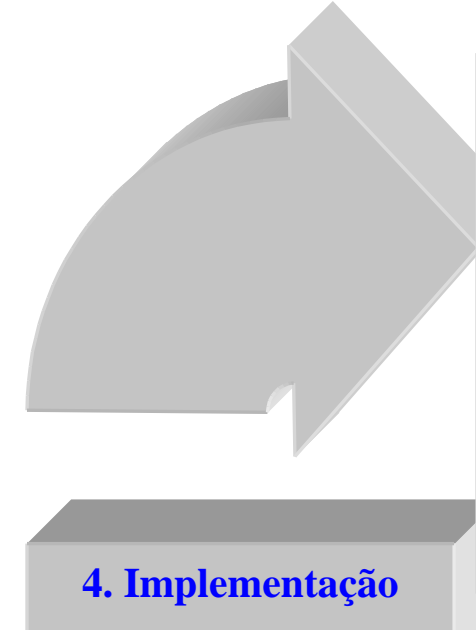

Desenvolver até a maturidade do produto.

Desenvolvimento tecnológico paralelo ao desenvolvimento mercado.

Lançamento.

Suporte pós vendas

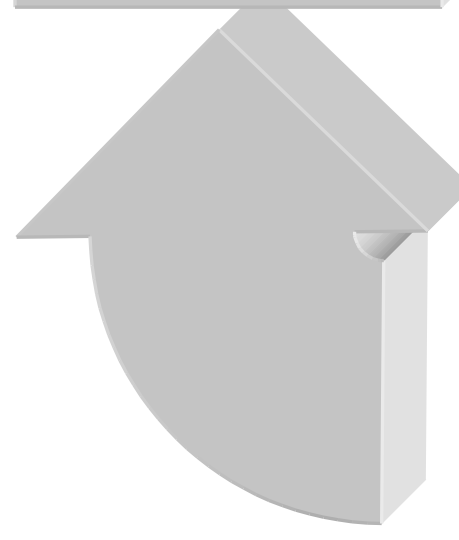

\section{Rastreamento}

Rastrear o ambiente para coleta de sinais de novas tecnologias, mercados, regulamentações, etc.

Coletar e pré selecionar os sinais observados.

Rastrear à frente, no tempo.

Avaliar os sinais, através de informações relevantes, para tomar decisões.

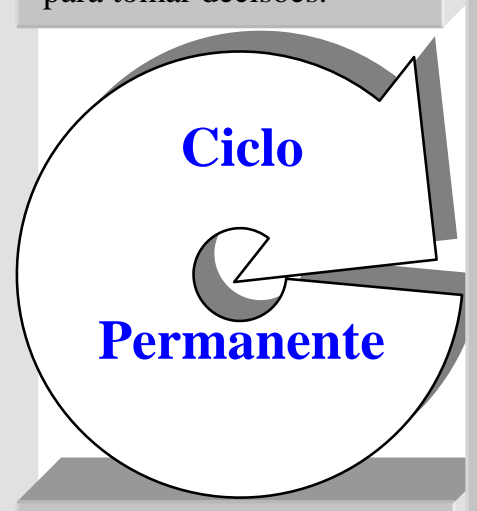

3. Obtenção de recursos

Buscar soluções adequadas à decisão estratégica.

Criar soluções domésticas, através de P\&D.

Usar de P\&D existentes. Adquirir P\&D através de contratos com o exterior. Licenciar ou adquirir.

Transferir tecnologia.

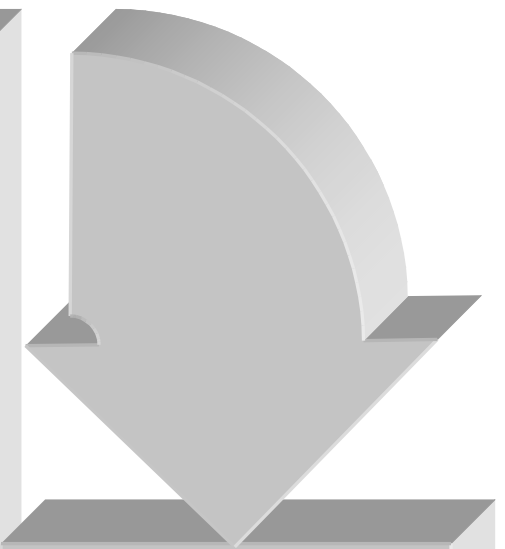

2. Estratégia

Analisar, escolher, planejar. Selecionar sinais em termos de possibilidades de ação. Conectar-se com todas as estratégias de negócios. Alertar bases internas de conhecimento e competência. Colher opções prioritárias. Alocar recursos necessários Planejar.

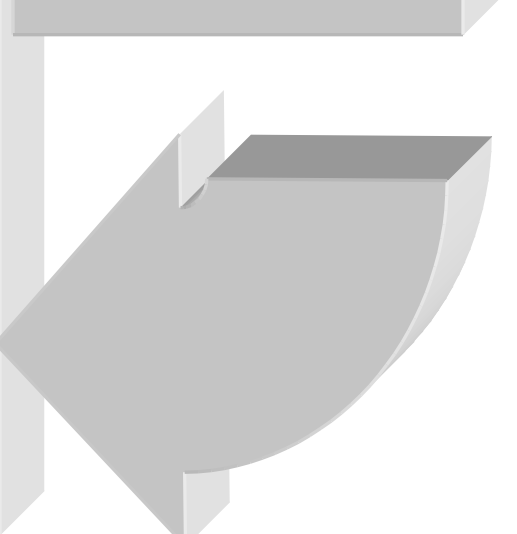

Figura 7: Ciclo do processo de inovação.

Fonte: Tidd, J. et alii: Managing Innovation, Integrating Technological, Market and Organizational Change. John Wiley \& Sons, London, 1997. 


\subsubsection{Rastreamento do ambiente interno e externo.}

A primeira fase da inovação envolve a verificação dos sinais de uma mudança potencial. Podem ocorrer na forma de novas oportunidades tecnológicas ou mudanças de mercado, resultantes de pressão de legislação ou ação da concorrência, conforme já comentado anteriormente. A maioria das inovações origina-se da interação de diversas forças, algumas originadas pelo estímulo tecnológico criado pelas inovações, e outras pelo estímulo do mercado, através de novas oportunidades.

Devido à variedade de sinais, é importante que a empresa tenha mecanismos bem desenvolvidos para a identificação, processamento e seleção das informações geradas pelo mercado.

\subsubsection{Estratégia - Escolha da oportunidade mais adequada}

Toda inovação é inerente a riscos. Apesar dos riscos serem inevitáveis, não é conveniente que a empresa exponha-se a essa situação; mesmo as empresas bem estruturadas não podem assumir riscos de modo sistemático. A crescente desregulamentação dos mercados mundiais vem estimulando a desestruturação dos mercados de trabalho, bem como reduzindo a responsabilidade do estado sobre as políticas sociais, conforme afirma Muniz, S. (2000). Isto tem gerado um crescimento financiado, fazendo com que o conhecimento tecnológico e científico passe a ser financiado pelo investimento privado. E o investimento privado dificilmente aceita riscos. Sendo assim, a escolha das possibilidades mais adequadas bem como a adequação à estratégia da empresa é fundamental. A finalidade desta fase é adequar-se os insumos necessários à inovação que será desenvolvida pela organização, de modo a reduzir ao máximo a possibilidade de riscos. Três insumos ou "entradas" compõem esta fase:

- Fluxo de informações sobre possíveis oportunidades tecnológicas e de mercado, adequados à empresa.

- Definição do segmento tecnológico da empresa - sua competência tecnológica mais acentuada. Através desta segunda entrada, verifica-se o que a empresa conhece em termos de produtos ou serviços envolvidos na inovação, e como estes serão utilizados e produzidos. Este conhecimento pode estar incorporado nos produtos ou equipamentos, mas também está presente nas pessoas (Capital Intelectual) e nos sistemas necessários ao processo de trabalho. Nesta etapa, é importante assegurar 
uma boa adequação entre o que a empresa conhece e as mudanças que ela pretende fazer, entretanto, sem "engessar" a empresa. Nesta fase a flexibilidade e agilidade da empresa são importantes, pois durante o processo de inovação a empresa pode detectar a necessidade de se deslocar para novas áreas de conhecimento, que podem ser eventualmente interessantes como fontes de inovações.

- Adequação aos negócios da empresa. Na fase conceitual é possível associar as inovações propostas à melhoria de desempenho geral dos negócios. Desse modo, fará sentido a empresa investir em equipamentos flexíveis de manufatura, caso sua inovação esteja se desenvolvendo em mercado onde a opção do cliente é um componente crítico. Mas, se a empresa atua em commodities, onde os consumidores procuram exatamente por um mesmo tipo de produto, a um baixo custo, o gasto em equipamentos flexíveis é um investimento sem sentido. $\mathrm{O}$ alinhamento entre a estratégia geral dos negócios e a estratégia de inovação é o ponto crítico neste estágio.

\subsubsection{Obtencão dos recursos necessários (P\&D, tecnologia, financiamentos, etc.)}

Esta fase envolve a combinação dos conhecimentos novos e disponíveis (internamente ou externamente à empresa), para chegar-se à solução do problema. Como esta é uma primeira fase no processo, pode sofrer várias mudanças. A fase de obtenção de recursos vem logo após a fase de detalhamento do desenvolvimento e antecede o conceito do projeto, o qual pode ser aprovado, revisado ou abandonado.

O que denominamos "invenção" é configurado como uma combinação de idéias ao redor do conceito; e este conceito pode surgir através de pesquisa de mercado, ação junto aos concorrentes ou ser resultado da $\mathrm{P} \& \mathrm{D}$ internos ou externos. $\mathrm{O}$ aspecto principal desta etapa é transformar a inovação, de um conjunto de idéias para a realidade física, e vai depender muito da natureza do novo conceito, que pode envolver a modificação de um produto já existente ou envolver um conceito totalmente novo.

Enquanto os indivíduos diferem-se no que diz respeito ao estilo de criatividade, há grande evidencia de que todos os indivíduos possuem uma capacidade criativa latente para a solução de problemas. Entretanto, inibições, pressões externas, pressões sociais e ambientais, restringem esta capacidade criativa. $O$ aspecto fundamental no gerenciamento desta fase, é criar condições para que a criatividade individual se manifeste, contribuindo efetivamente para a inovação. 
Outro aspecto importante nesta fase, é o equilíbrio entre as condições que estimulam o comportamento criativo e as dificuldades de várias naturezas que envolvem o processo de inovação. O desafio da $\mathrm{P} \& \mathrm{D}$ não é apenas a alocação adequada dos recursos, mas também como eles serão utilizados. Neste aspecto, a gestão eficaz é feita através da organização das rotinas, definição da direção estratégica, comunicação eficiente e integração dos esforços das várias equipes envolvidas.

No caso das pequenas empresas, que nem sempre podem estar investindo em P\&D, o desafio é encontrar acesso à tecnologia desenvolvida por outras empresas, ou complementar os conhecimentos internos, através de uma série de possibilidades. As empresas podem sobreviver sem o desenvolvimento interno de conhecimento, porém devem desenvolver um canal eficiente para a busca de fontes externas e desenvolver a habilidade em colocar a tecnologia adquirida em uso.

\subsubsection{Implementacão do projeto.}

Esta fase é o coração do processo de inovação. Os conceitos estratégicos devem estar claros e as idéias preliminares a respeito do produto já devem estar definidas. Podemos dizer que os conceitos e idéias representam insumos que se destinam tanto ao desenvolvimento da inovação quanto à preparação do mercado para o lançamento final. Nesta etapa parte-se de uma ampla exploração, com redução gradativa de variáveis. O foco está na solução dos problemas, resultando na colocação da inovação no mercado.

Nesta fase incorre a maior parte dos custos, compromissos e tempo gasto. Ocorre também a maior parte das falhas previstas ou não, exigindo a atividade de solução de problemas, muito bem estruturada, com forte interação entre mercado e atividades técnicas, a fim de evitar-se desenvolvimentos inadequados, sem a inclusão das necessidades do cliente, ou ao contrário, levar a uma "sobre engenharia" tornando o produto sofisticado, com solução que excede a expectativa do cliente.

De modo similar, a ausência de conexão com a manufatura pode levar à falta de informações necessárias à "fabricabilidade" do produto, tornando-o de processamento crítico.

Paralelamente à atividade de resolução de problemas, existem as atividades de preparação do mercado para o lançamento. Um aspecto importante do esforço de marketing é a antecipação das respostas prováveis ao conceito do novo produto, usando- 
se estas informações na concepção final do produto e na maneira como o mesmo será lançado no mercado.

O comportamento do comprador também é um aspecto crítico, mas existem várias linhas de atuação que podem auxiliar nesta atividade. A primeira é o estabelecimento do processo de adoção de algo novo; envolvendo uma sequiência de conscientização, interesses, tentativas, avaliações e adoção. Simplesmente tornar o público consciente via publicidade - da existência de um novo produto, pode não ser suficiente; os consumidores devem passar pelas outras etapas.

\subsection{O Capital Intelectual}

O modelo de inovação vigente na indústria, até o final dos anos 70, apresentava uma sequiência linear; era uma atividade que ia da descoberta científica até a entrada no processo fabril, passando pela pesquisa básica (universidades), pesquisa aplicada (centros ou instituições públicas), execução de protótipos, marketing e vendas. A inovação estava centrada na invenção. Conforme Muniz, S. (2000), a partir do início dos anos 80 o processo de inovação passou por mudanças, agregando processos de difusão, imitação, aperfeiçoamento e cadeia logística, além dos processos já existentes. É a partir do início dos anos 80 que fica claro que o processo de inovação se trata de uma transposição da idéia para a disponibilização comercial de um produto ou serviço. A cadeia de atividades incorporadas ao processo de inovação exige profissionais mais especializados e versáteis. O capital intelectual começa a assumir um aspecto mais estratégicos.

Por outro lado, conforme discutimos anteriormente, a inovação tanto pode ser uma grande fonte de recursos e vantagens competitivas, como pode ser uma fonte de incertezas e gastos sem retorno. Entretanto, e em função disso, a inovação e a maior fonte geradora de conhecimentos dentro de uma empresa.

Todo esse conhecimento, base de sustentação do processo de inovação, deve ser consistente e bem administrado pela empresa, através da construção de seu capital intelectual. 


\subsubsection{O que é o Capital Intelectual?}

De acordo com citação feita por Terra, J.C.C. (1999), Peter Drucker criou, há 4 décadas atrás, o termo "trabalhador do conhecimento" , tornando-se um dos primeiros teóricos organizacionais a destacar a importância do conhecimento tanto para o trabalho técnico como para o trabalho não técnico. Desde o início até os dias de hoje, Drucker comenta que se evoluiu muito pouco na formulação de uma economia que leve em conta o conhecimento como principal recurso para a produção de bens e serviços.

Conforme salientado por Muniz, S. (2000), a partir dos anos 80 a economia começa um processo de mudança de um regime baseado no petróleo e demais materiais intensivos em energia (petroquímicos e sintéticos) para um regime baseado na tecnologia da informação e comunicação. O modelo anterior justificava uma estrutura organizacional com capacitações intermediárias (chefes, encarregados, mestres, técnicos, etc.); o modelo atual, que surge a partir dos anos 80, exige novos critérios de avaliação gerencial. A produção não está mais baseada puramente em processos técnicos e sim em ferramentas de desempenho pessoal tais como compras, financiamentos, produção, P\&D, marketing.

Existem várias definições a respeito do que é o capital intelectual.

Segundo Edvinsson, L. \& Malone, M. (1997) o capital intelectual é formado por:

1. Capital Humano: formado pelos valores, cultura e filosofia da empresa, além da capacidade individual de seus funcionários em combinar conhecimentos e habilidades para inovar e fazer o trabalho. É um capital não negociável;

2. Capital estrutural: Inclui o Hardware, software, bases de dados, patentes, marcas, etc. É tudo o que fica na empresa quando os funcionários vão para casa. É propriedade da empresa e pode ser objeto de transação comercial.

Segundo Sveiby, K. E. (1997), é formado por:

1. Competência dos funcionários;

2. Estrutura interna, que inclui patentes, conceitos, modelos e sistemas administrativos e de informática; 
3. Estrutura externa, que inclui as relações com os clientes e fornecedores, marcas, reputação e imagem da empresa.

Segundo Brooking, A. (1997), é formado por:

1. Ativos de Mercado;

2. Ativos baseados em funcionários;

3. Ativos relacionados à propriedade intelectual;

4. Ativos de infra-estrutura.

Entretanto, uma definição simples e que nos parece sintetizar melhor este conceito, é dada por Klein, D. \& Prusak, L. (1994), segundo os quais, “ é o material intelectual que foi formado, capturado e alavancado a fim de produzir um ativo de valor maior". Devemos observar que dentro desta definição surge um outro termo, o "material intelectual". Segundo esses próprios autores, material intelectual pode ser um artigo de um jornal, um relatório, um catálogo técnico, endereços de empresas, etc. Porém nada disso é capital intelectual. A ordenação dessas informações de forma coordenada e útil é que forma o capital intelectual.

\subsubsection{O capital intelectual e a empresa}

Existe uma relação direta entre o capital intelectual e a competência interna da empresa. Através de pesquisas efetuadas por Prahalad, C.K. e Hamel, G. (1990), estes concluíram que a vantagem competitiva de uma empresa reside na competência interna, e esta é que tem capacidade de, através da inovação, gerar os produtos que irão ampliar e manter as margens de mercado. Estes autores utilizaram a analogia com uma árvore para classificar a competência interna de uma empresa, conforme segue:

- Produto final - São as folhas e os frutos de uma árvore.

- Unidades de negócios - São os galhos da árvore.

- Equipamentos e estrutura internos - São o tronco da árvore.

- Competência interna (capital intelectual) - São a raiz do sistema empresarial

A importância do capital intelectual foi reconhecida essencialmente no início dos anos 90, justamente quando foi dada grande ênfase às teorias de enxugamento. À primeira 
vista isto pode parecer um contra senso: A valorização do capital intelectual surge quando este é enquadrado nos processos de redução.

Este aparente contra senso surgido nos anos 90 começou com a busca das empresas por melhorias de resultados operacionais no curto e médio prazo, através do aumento da eficiência e flexibilidade. Foram implantadas várias teorias, tais como "downsizing", horizontalização, terceirização, e reengenharia, entre outras. Isto conduziu as empresas ao que denominamos "administração enxuta". Porém, a partir daí foram sendo detectados sinais preocupantes quanto à competência interna das empresas. Começaram a surgir empresas com perfis até então desconhecidos:

- Empresas anoréxicas: não apresentam capacidade de reter o conhecimento, perdendo sua capacidade de mudanças ou sobrevivência em longo prazo.

- Empresas amnésicas: Com a redução do pessoal, ela perdeu parte essencial de sua memória, perdendo sua capacidade de inovação.

Esta classificação, abordada por Tidd, J. et alii (1997) é que deu início à revisão dos conceitos sobre o capital intelectual, denominado também de ativo intelectual.

Hoje as empresas precisam aprender a gerenciar o seu capital intelectual. A gerência dos ativos intelectuais tornou-se a tarefa mais importante dos negócios, porque o conhecimento tornou-se o fator mais importante da produção.

Segundo Peter Drucker, desde 1900, a quantidade de trabalho necessária para se fazer uma unidade adicional de produto, vem caindo $1 \%$ ao ano, à medida que as máquinas realizam mais trabalhos em lugar dos homens.

De acordo com Stewart T.A. (1998), inicialmente, antes da revolução industrial, o fator de riqueza das nações e ativos mais importantes das empresas eram os recursos naturais (terras, minérios, animais, etc.). Em seguida, com a revolução industrial, o capital (dinheiro, bens, máquinas, fábricas, etc.) assumiu este papel. Hoje é o capital intelectual que assumiu esta importância. Estamos na era da informação (pós Era Industrial), na qual a riqueza é o produto do conhecimento. 


\subsection{A área de Pesquisa e Desenvolvimento}

Quando se fala em Pesquisa e Desenvolvimento (P\&D), uma das primeiras questões que nos ocorre é a escolha da empresa, ou seja, o que leva uma empresa a escolher determinado tipo ou área de trabalho, ou, determinado tipo de inovação. Este processo reflete uma escolha isolada da empresa ou está inserido dentro de um contexto maior? As pesquisas tem demonstrado que a influência da política de cada país é fundamental para a segmentação do processo de inovação de seu parque industrial.

Em seguida à influência da política do país, surge como segunda maior influência, o ambiente competitivo nacional. Ambos serão discutidos nesta seção do capítulo 2.

\subsubsection{A influência da política nacional}

O ambiente tecnológico do país onde está situada a empresa é o fator de maior influência sobre sua estratégia de inovação. De acordo com estudos de Porter, M. (1990), a política tecnológica nacional exerce uma forte influência sobre a escolha tecnológica das grandes empresas. É a partir delas que esta influência nacional se difunde e se irradia para todas as demais empresas do mercado. No caso das empresas de pequeno e médio porte, a definição do seu campo tecnológico tem relação direta com a política das grandes empresas, que por sua vez, tem a sua política tecnológica influenciada pelo país de origem. Segundo Malerba, F. e Orsenigo, L. (1996) o ambiente tecnológico onde a empresa está inserida apresenta as seguintes características:

- Oportunidade tecnológica,

- Apropriabilidade, ou seja, o grau de proteção contra a concorrência,

- Cumulatividade, ou seja, o grau de aprendizado tecnológico da empresa,

- Base de conhecimento, característica associada ao grau de complexidade tecnológica e de componentes, implícitos ao produto da empresa.

De acordo com os autores, quanto maiores forem a apropriabilidade e a base de conhecimentos entre as empresas, maiores as possibilidades de alianças estratégicas.

Em 1990 a revista Business Week publicava uma reportagem na qual afirmava-se que as empresas globais dependiam fortemente da política de seus países de origem para 
operarem no mercado global. As empresas mundiais eram fortemente influenciadas pelas condições de suas nações sede na escolha de sua estratégia tecnológica. Outro dado que confirma esta premissa foi fornecido através de uma pesquisa de Cantwell, J. (1992), segundo o qual, apenas $10 \%$ das atividades voltadas à inovação, das 500 maiores empresas do mundo, estavam localizadas fora de seus países de origem, apesar de $25 \%$ de suas vendas estarem localizadas fora de seus países de origem.

A conclusão à qual podemos chegar, é que a política de inovação das pequenas e médias empresas, muitas vezes é originada fora de seus países de origem, uma vez que a maioria dessas 500 maiores empresas está localizada nos Estados Unidos da América e Alemanha ${ }^{4}$.

\subsubsection{Um indicador nacional da política de investimento em inovacão.}

Um dos melhores indicadores da política nacional de apoio à inovação é a relação entre investimento em P\&D e Produto Interno Bruto (PIB) de cada país. De acordo com Fagerberg, J. (1987) a atividade de inovação de um país, medida através de gastos em $\mathrm{P} \& \mathrm{D}$ expressos na forma de porcentagem do PIB, tem algumas imperfeições, entretanto ainda é o melhor indicador dessa atividade. As imperfeições ocorrem em função do perfil industrial do país. Como exemplo, Fagerberg cita o Canadá e a Finlândia, países cuja porcentagem do PIB referente a investimento em $P \& D$ não reflete a estrutura industrial desses países, visto que as economias de ambos estão fortemente ligadas à extração de recursos naturais, atividade pouco dependente de processos de inovação. Entretanto, o percentual do PIB ainda é o fator que melhor reflete o perfil inovador de cada país.

A tabela a seguir foi montada com os dados de nove países tradicionais em atividades inovadoras, relacionando-se os gastos em P\&D expressos na forma de percentagem do PIB. Os dados obtidos confirmam a tendência dos países analisados:

\footnotetext{
${ }^{4}$ Outra conclusão interessante de Cantwell, J. (1992) é a de que mais de $80 \%$ dos investimentos em inovação (ou seja, em P\&D) são efetuados nos países de origem das grandes empresas, notadamente, EUA e Alemanha. Além disso, a maior parte dos investimentos em inovação, feita por empresas de capital não originário dos EUA e Alemanha , é feita nesses dois países. Ou seja, o país “berço" das mega empresas é quem determina a política de inovação global. Estas conclusões contrariam o senso comum segundo o qual as multinacionais não tem pátria ou nacionalidade. De acordo com Tidd, J. et alii a respeito desse assunto, os EUA e a Alemanha não estão globalizados, e sim, globalizaram o mundo.
} 
Tabela 2 : Tendência de gastos em Pesquisa e Desenvolvimento (P\&D), expressos como percentagem do PIB.

\begin{tabular}{|c|c|c|c|c|c|c|c|c|c|c|c|c|c|}
\hline Ano & 67 & 69 & 71 & 75 & 77 & 79 & 81 & 83 & 85 & 87 & 89 & 91 & 93 \\
País & & & & & & & & & & & & & \\
\hline Japão & 0,83 & 1,00 & 1,09 & 1,12 & 1,11 & 1,19 & 1,38 & 1,59 & 1,81 & 1,82 & 2,05 & 2,13 & 1,90 \\
\hline Suécia & 0,71 & 0,69 & 0,80 & 0,96 & 1,07 & 1,11 & 1,24 & 1,45 & 1,71 & 1,73 & 1,65 & 1,69 & 1,86 \\
\hline Suíça & 1,78 & 1,78 & 1,67 & 1,67 & 1,71 & 1,74 & 1,68 & 1,67 & 1,79 & 1,92 & 2,05 & 1,79 & 1,79 \\
\hline EUA & 0,99 & 1,03 & 0,97 & 0,98 & 0,98 & 1,05 & 1,17 & 1,31 & 1,42 & 1,37 & 1,41 & 1,60 & 1,57 \\
\hline Alemanha & 0,94 & 1,03 & 1,13 & 1,11 & 1,12 & 1,32 & 1,40 & 1,48 & 1,65 & 1,80 & 1,78 & 1,58 & 1,45 \\
\hline Reino Unido & 1,00 & 0,92 & 0,81 & 0,80 & 0,80 & 0,92 & 0,91 & 0,86 & 0,95 & 1,02 & 1,04 & 0,99 & 1,04 \\
\hline Holanda & 1,12 & 1,04 & 1,02 & 0,97 & 0,87 & 0,86 & 0,83 & 0,89 & 0,97 & 1,11 & 1,06 & 0,91 & 0,86 \\
\hline Finlândia & 0,30 & 0,32 & 0,44 & 0,44 & 0,49 & 0,53 & 0,62 & 0,73 & 0,90 & 0,99 & 1,09 & 1,10 & 1,20 \\
\hline Canadá & 0,40 & 0,39 & 0,38 & 0,33 & 0,32 & 0,39 & 0,49 & 0,46 & 0,57 & 0,57 & 0,55 & 0,58 & 0,58 \\
\hline Edos índices & 8,07 & 8,2 & 8,31 & 8,38 & 8,47 & 9,11 & 9,72 & 10,4 & 11,8 & 12,3 & 12,7 & 12,4 & 12,3 \\
\hline \% Médio & 0,9 & 0,91 & 0,92 & 0,93 & 0,94 & 1,01 & 1,08 & 1,16 & 1,31 & 1,37 & 1,41 & 1,37 & 1,36 \\
\hline
\end{tabular}

Fonte: Tidd, J. et alii: Managing Innovation, Integrating Technological, Market and Organizational Change. John Wiley \& Sons, London, 1997.

Com os dados da tabela, obtendo-se a média anual, construímos o gráfico abaixo, a fim de ilustrar a tendência do investimento em inovação nas últimas 3 décadas:

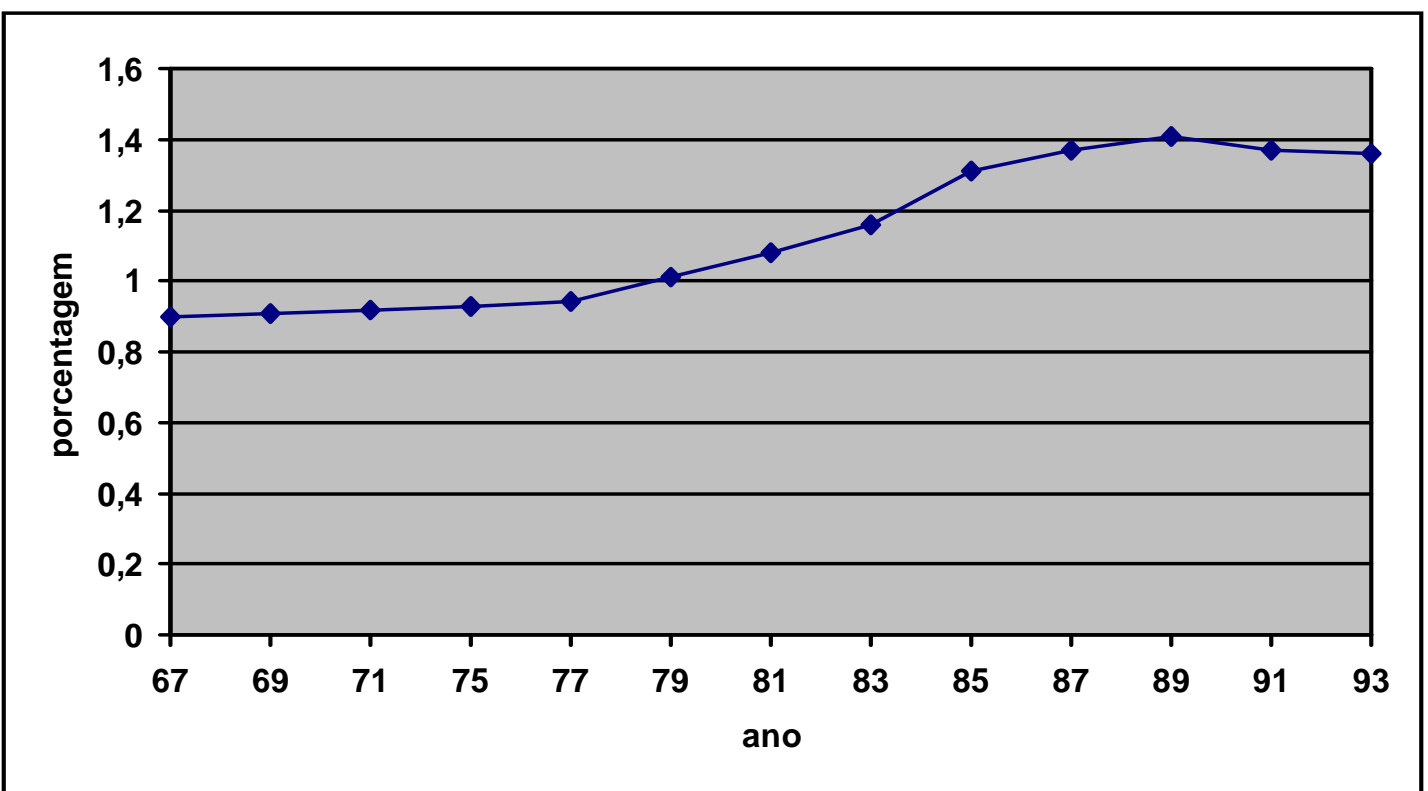

Figura 8: Evolução do percentual médio do PIB, investido em atividades voltadas à inovação (P\&D).

Fonte: Adaptado de Tidd, J. et alii: Managing Innovation, Integrating Technological, Market and Organizational Change.Observação: Os valores correspondentes aos anos 90 e 92 para os Demais Países (Tabela 2) foram interpolados, devido à não disponibilidade. 


\subsubsection{Indicador Brasileiro da Inovacão}

Para situarmos o processo de inovação dentro do contexto nacional, é importante a inclusão dos dados do Ministério da Ciência e Tecnologia, nos mesmos padrões dos dados de investimento dos outros países.

Com base nos Indicadores Nacionais em Ciência e Tecnologia, divulgados pelo Ministério da Ciência e Tecnologia, período 90 a 96, foi possível traçar um paralelo com os dados mundiais indicados no item 2.5.1.1, conforme segue:

Tabela 3 : Percentual do PIB brasileiro dispendido em P\&D

\begin{tabular}{|c|c|c|c|c|c|c|c|}
\hline Dispêndios & 90 & 91 & 92 & 93 & 94 & 95 & 96 \\
\hline PIB & $605.174,9$ & $611.421,5$ & $608.094,9$ & $638.041,7$ & $675.385,4$ & $703.912,3$ & $723.340,3$ \\
\hline P\&D & $2.801,2$ & $2.834,4$ & $2.320,9$ & $3.072,0$ & $4.656,8$ & $5.359,8$ & $5.484,4$ \\
\hline P\&D/PIB & 0,46 & 0,46 & 0,38 & 0,48 & 0,69 & 0,76 & 0,76 \\
\hline
\end{tabular}

Fonte: Ministério da Ciência e Tecnologia: Indicadores Nacionais de Ciência e Tecnologia do período 90/97. Observação: em US\$ milhões de 1995

Os dados obtidos com o relatório do MICT mostram que a evolução desse percentual do PIB aplicado em P\&D tem aumentado significativamente desde o início da década de 90, apresentando um crescimento de $65 \%$ entre 90 e 96 . O investimento em P\&D passou de 0,46\% para 0,76\% do PIB. Entretanto, apesar dessa evolução de 65\%, estamos muito distantes da média dos países indicados na tabela 2.

Com os dados da tabela 3 acima podemos estabelecer um gráfico comparativo com os demais países, representados na figura a seguir: 


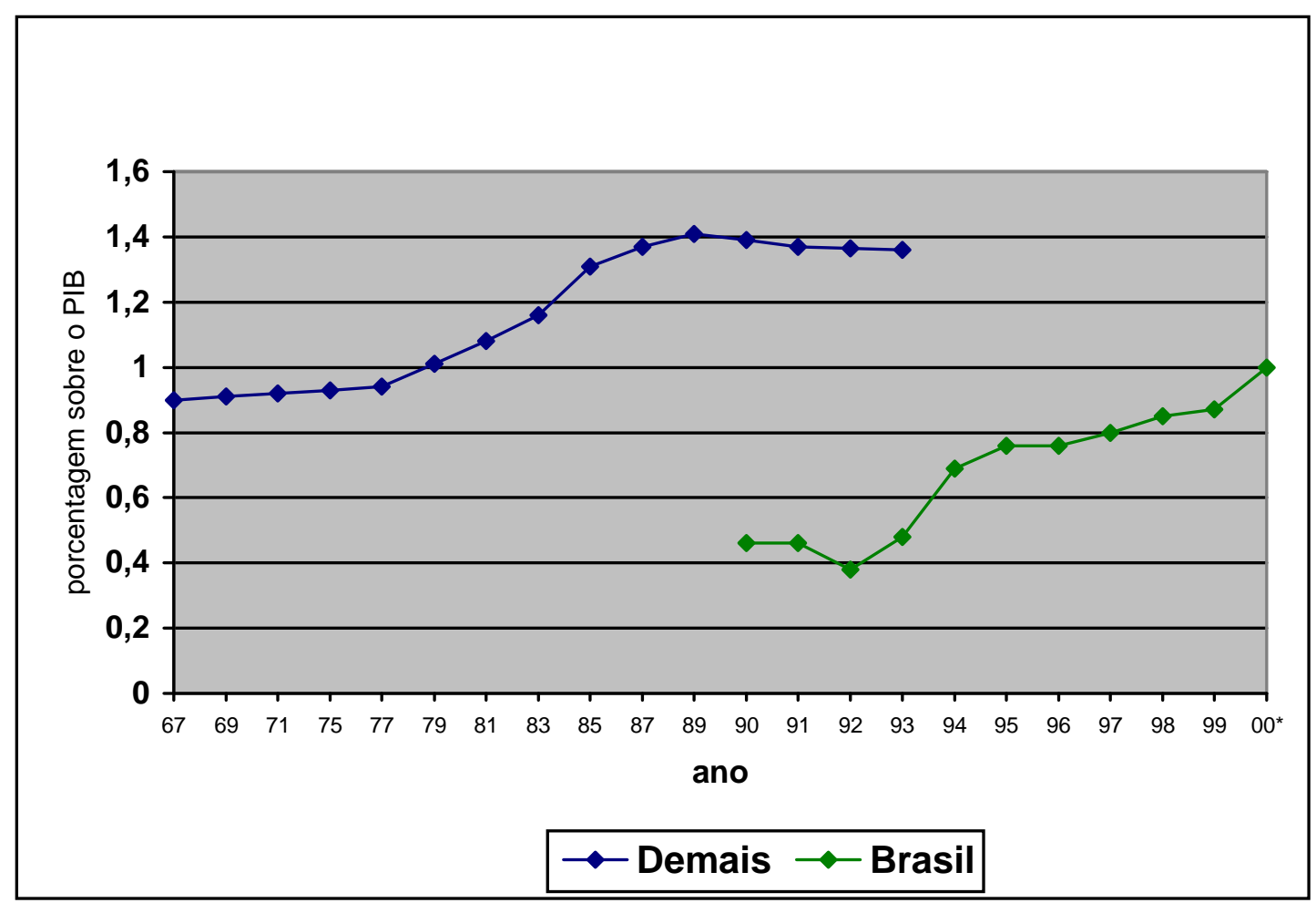

Figura 9 : Evolução média do percentual do PIB aplicado em P\&D, comparada à evolução do percentual do Brasil.

Fonte: Adaptado de Tidd, J. et alii: Managing Innovation, Integrating Technological, Market and Organizational Change junto aos dados do MCT e CNPq.

Observação: Os valores correspondentes aos anos 90 e 92 para os Demais Países (Tabela 2) foram interpolados, devido à não disponibilidade.

Através do gráfico acima podemos perceber que o percentual do PIB aplicado em P\&D no Brasil está muito distante da média dos 9 países abordados. Não atingimos o patamar médio da década de 60 desses países, além do que, há uma tendência muito clara de estabilização do percentual brasileiro no patamar atual, na faixa dos $0,80 \%$ do PIB, enquanto os demais 9 países apresentam tendência de estabilização no patamar dos $1,40 \%$. A diferença entre os índices, ao redor de $75 \%$, é bastante significativa.

Outro aspecto importante a ser observado é a origem desse investimento. O relatório do MICT estabelece 4 setores distintos:

- Governo Federal;

- Governos Estadual e Municipal; 
- Instituições Privadas de Ensino;

- Setor Empresarial, ou setor privado.

De acordo com o relatório do MICT, os governos federal, estadual e municipal englobam as respectivas instituições de ensino superior e órgãos públicos de pesquisa. Pode-se notar que os 3 governos são responsáveis por praticamente $66 \%$ do investimento em $\mathrm{P} \& \mathrm{D}$, restando uma parcela irrisória às instituições privadas de ensino e uma parcela também pequena ao setor privado ( $31 \%$ do total ou $0,23 \%$ do PIB brasileiro), conforme resumido na figura abaixo:

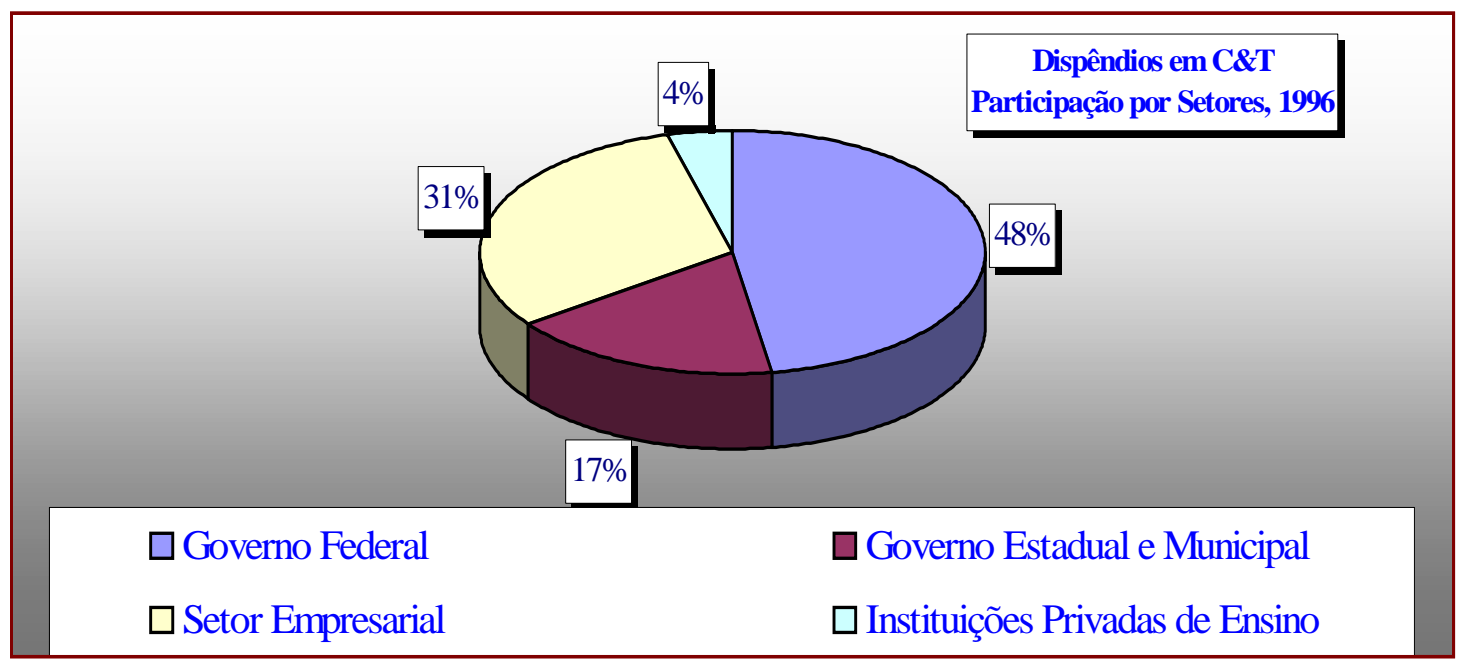

Figura 10 : Participação de cada setor da economia nos gastos com Ciência e Tecnologia.

Fonte: Ministério da Ciência e Tecnologia: Indicadores Nacionais de Ciência e Tecnologia do período 90/97.

É interessante observar na figura acima a confirmação da teoria de Cantwell, J. (1992) incluída na página 38 ,com relação ao investimento feito por parte das maiores multinacionais do mundo. De fato, se considerarmos que dentro do setor empresarial privado encontram-se empresas de capital nacional, empresas de economia mista e multinacionais instaladas no país, verificamos que o percentual de investimento destas últimas é pequeno, visto que elas investem preferencialmente em seus países de origem $^{5}$. Isto representa um ponto crítico, pois faz com que a política de inovação da

\footnotetext{
${ }^{5}$ Apesar desses dados, vale ressaltar que o percentual do PIB brasileiro aplicado em P\&D é maior que o percentual apresentado pelo Canadá e praticamente equivalente ao percentual da Holanda, conforme a Tabela 2 : Tendência de gastos em Pesquisa e Desenvolvimento (P\&D), expressos como percentagem do PIB.
} 
pequena e média empresa privada do país esteja seguindo uma política ditada pelos governos dos países mais desenvolvidos, sedes das grandes corporações, o que nem sempre pode ser o mais adequado à política industrial do país.

\subsection{Fontes de Inovacão - Porque buscar a parceria}

Conforme já comentamos, toda inovação envolve riscos e esses riscos podem ser traduzidos por custos. A inovação envolve o custo de desenvolvimento tecnológico, o custo de processamento do produto, o custo de colocação do produto no mercado, dentre outros. A empresa corre o risco de ter esses custos, mas não ter a contrapartida, que é o retorno do investimento. Vale lembrar que dentro de um processo de inovação podem existir várias tecnologias diferentes envolvidas; alguns aspectos tecnológicos podem estar relacionados à especialização da empresa. Entretanto, outros aspectos tecnológicos podem ser considerados periféricos a esta empresa, sendo o foco de especialização de outras empresas ${ }^{6}$.

A fim de reduzir esses risco ao mínimo, a empresa deve buscar a colaboração de suas parceiras de mercado, através de alianças ou fusões.

De acordo com Tidd, J. et alii (1997) as principais razões para que uma empresa busque alianças ou fusões podem ser agrupadas em três classes diferentes:

- Tecnológica: Esta razão envolve os aspectos relacionados aos custos, complexidade e prazo de desenvolvimento de uma inovação. Neste aspecto, a eficiência financeira é o foco de maior atenção. A empresa deve estar ciente de que seus conhecimentos periféricos são a especialização de outras empresas.

- Organizacional: A empresa deve saber avaliar sua competência interna, a fim de estabelecer os limites entre o desenvolvimento interno e a busca de soluções externas. Neste caso também a empresa deve saber avaliar sua cultura interna e sua

\footnotetext{
${ }^{6}$ Um exemplo bastante típico é o da indústria automobilística. Devido à velocidade com que os modelos novos são lançados atualmente e também devido à complexidade crescente das tecnologias envolvidas nos produtos (os automóveis contam com sistemas complexos de hardware e software, por exemplo), não há sentido para a empresa desenvolver sozinha todas as tecnologias envolvidas. Os custos e prazos envolvidos seriam proibitivos. Por isso, cada vez mais, os sistemas envolvidos nos automóveis são desenvolvidos pelas próprias empresas fabricantes de autopeças, em regime de parceria com as montadoras. O mesmo pode-se dizer a respeito das empresas de informática. Para uma empresa que desenvolve software, não há sentido investir em mão de obra e equipamento para a fabricação dos componentes mecânicos. Neste caso também, o regime de parceria é estratégico.
} 
capacidade gerencial, tanto para o desenvolvimento interno quanto para uma transferência de tecnologia.

- Planejamento: A empresa deve selecionar criteriosamente sua parceria, levando em consideração aspectos voltados à confiança entre as empresas, à capacidade de comunicação entre ambas e os objetivos e recompensas previstos. Neste caso, de acordo com Mc Gee, J.E. e Dowling, M.J. (1994) a empresa deve ter muita atenção aos aspectos relacionados ao que eles denominam "oportunismo tecnológico" . De acordo com os autores, o oportunismo tecnológico é caracterizado pelos altos custos da tecnologia envolvida ${ }^{7}$ ou pelo baixo desempenho da empresa fornecedora de tecnologia (quando há poucas empresas dominantes de um determinado conhecimento). Quanto menos fontes de tecnologia, menor é a margem de manobra da empresa que busca essa tecnologia. Nestes casos, os cuidados no planejamento devem ser maiores.

De acordo com Welch, J. A. (1992), qualquer que seja a razão da empresa para a busca de tecnologia, os melhores resultados dependerão da maturidade tecnológica envolvida, da posição da empresa detentora de tecnologia frente aos concorrentes e da estratégia dessa tecnologia. Ainda de acordo com o autor, sempre há necessidade de algum tipo de colaboração entre empresas, quando a tecnologia é nova, complexa ou escassa. Quando a tecnologia é simples, madura e disponível, é suficiente para a empresa um contrato de licenciamento ou até mesmo uma subcontratação.

Isso nos leva à conclusão em que os aspectos estratégicos são os mais importantes. A prática tem mostrado que no processo de transferência tecnológica, os custos envolvidos tornam-se menos importantes que os aspectos estratégicos. Isto ocorre porque o objetivo primordial da empresa que busca a tecnologia, é a vantagem competitiva, a expansão de seu mercado e o aumento da gama de produtos a serem

\footnotetext{
${ }^{7}$ Um exemplo bastante significativo dentro do mercado brasileiro é o da empresa Multibrás S.A. , que controlava as marcas Brastemp, Consul, Semmer, e era a maior fabricante mundial de compressores para refrigeração. Essa empresa mantinha acordo tecnológico com a empresa Whirlpool Inc. A transferência tecnológica era feita através da cessão de participações acionárias. A Multibrás, que era constituída de capital $100 \%$ nacional foi desnacionalizando-se gradativamente em troca de tecnologia, até culminar com o controle total do capital estrangeiro. Nesse caso, o planejamento estratégico da empresa não foi adequado aos interesses nacionais.
} 
oferecidos aos clientes, de acordo com o que complementa Atuaheme-Gima, K. e Patterson, P. (1993).

\subsubsection{As principais formas de colaboracão}

De modo geral, nenhum tipo de colaboração é ótima em sua totalidade. Algumas empresas preferem a parceria enquanto outras preferem a aquisição.

A união entre empresas pode ser do tipo horizontal, quando ocorrem licenciamentos mútuos, consórcios e a colaboração entre concorrentes potenciais para o complementação tecnológica, e do tipo vertical quando ocorre subcontratação, acordos com fornecedores ou clientes. A seguir, faremos um resumo de cada forma de colaboração possível entre empresas:

\subsubsection{Subcontratação}

O foco estratégico é unir para crescer. Na prática, esta união é feita para a redução de custos, pois os fornecedores podem reduzir seus custos fixos e variáveis, beneficiandose da economia de escala. Os fatores críticos desta união são a qualidade e a adequação do relacionamento entre empresas para o desenvolvimento conjunto. Este modelo foi expandido no Japão e tem sido muito usado pela indústria ocidental ultimamente, com a diferença que no Japão esta união é de longo prazo enquanto no ocidente é de curto prazo. É uma união do tipo vertical.

\subsubsection{Licenca Tecnológica}

É a oportunidade de uma empresa explorar a propriedade intelectual de outra, em troca de direitos e comissões de vendas. O licenciamento de tecnologia tem uma série de vantagens tais como redução de custos de desenvolvimento, menores riscos tecnológicos e de mercado, menor ciclo de desenvolvimento do produto. Uma pesquisa do tipo levantamento (survey) feita por Atuaheme-Gima, K. e Patterson, P. (1993) com mais de 200 empresas do ramo químico, de engenharia e farmacêutica na Inglaterra, indicou que as razões mais importantes para este tipo de fusão eram a rapidez de acesso à tecnologia, vantagem sobre competidores e aumento das vendas, consideradas mais importantes que a redução de custos. Os problemas relacionados a este tipo de associação são os custos inerentes à seleção do melhor parceiro e melhor tecnologia, e a perda do controle da tomada de decisões. 


\subsubsection{Consórcio de Pesquisa}

É um grupo de organizações trabalhando em conjunto, em determinado projeto. A vantagem está na divisão dos custos e riscos do projeto, preenchimento das lacunas em termos de especialistas e equipamentos, salto sobre a concorrência e difusão do conhecimento. De acordo com Tidd, J. et alii (1998), as empresas européias geralmente investem em equipamento em conjunto, ou em uma nova unidade independente. As empresas americanas geralmente alocam a pesquisa em cada um dos vários membros do consórcio, coordenando a pesquisa individualmente em cada empresa. O Japão tem adotado um modelo híbrido, no qual se compartilham os equipamentos e paralelamente executam-se pesquisas internas independentemente. Estes autores citam o exemplo da MCC - Microelectronic and Computer Technology Corporation, criada nos Estados Unidos em 1982, pela associação de Sperry, NCR, DEC, Honeywell, AMD, Motorola, entre outras, a fim de vencer a perda de competitividade da indústria de computadores nos EUA.

\subsubsection{Aliancas Estratégicas}

Tanto formal quanto informalmente, a aliança, também denominada rede empresarial (ou empresas rede), é um acordo entre duas ou mais empresas com a finalidade de codesenvolver um projeto em conjunto. De acordo com a OCDE, em seu relatório de 1992, este tipo de organização de produção é um dos dois grandes eixos em torno dos quais se organiza a produção industrial contemporânea (o outro é a tradicional gestão da produção e trabalho dentro da própria empresa).

Este tipo de colaboração, mesmo de modo informal, é bastante utilizado em empresas de pequeno, médio e grande porte. É o caso de empresas como Philips e Sony, que desenvolvem projetos em conjunto, mantendo suas estruturas organizacionais inalteradas. Dentro desta forma de colaboração há um modelo de inovação proposto por Kline, S.J.e Rosemberg, N. (1986) composto pelas seguintes atividades:

- Invenção ou Projeto,

- Detalhamento do Projeto e Teste,

- Reprojeto e produção.

A vantagem deste método proposto é permitir que as inovações não se iniciem necessariamente pela pesquisa, pois as informações acumuladas entre as empresas 
participantes tornam a fase inicial mais curta, menos onerosa e com menores riscos aos participantes. De acordo com Gibbons, M. et alli (1996) as alianças estratégicas passaram a ganhar maior força a partir dos anos 80, em função do clima de incerteza econômica e rápida mudança tecnológica. Conforme os autores, as principais razões para a formação de alianças estratégicas entre empresas são:

- Redução dos custos de P\&D,

- Facilidade de acesso a tecnologias complementares,

- Obtenção da tecnologia de parceiros de segmento industrial,

- Redução do ciclo de vida dos produtos,

- Divisão dos custos de desenvolvimento,

- Acesso aos mercados externos,

- Acesso a profissionais qualificados,

- Facilidade de acesso a recursos financeiros,

- Rapidez de resposta à incerteza tecnológica e a oscilações de mercado.

\subsubsection{Joint Ventures (Contratos de Risco)}

É o tipo de união em que duas ou mais organizações, que permanecem separadas, fazem a criação de uma nova empresa com recursos compartilhados, ou do tipo em que é feito um contrato baseado na cooperação. Como exemplo, podemos citar a Airbus Industrie, criada pela associação entre MBB (Alemanha), Aerospatiale (França), CASA (Espanha) e Britsh Aerospace (Inglaterra). No Brasil, este tipo de colaboração é bastante difundida.

\subsubsection{Canais de Inovação}

É um conceito recente, no qual são criadas muitas das vantagens de um desenvolvimento interno, e poucas desvantagens de uma colaboração entre empresas (ingerência, conflitos, etc.). O exemplo mais significativo de canal de inovação, são as incubadoras de empresas, como os vários núcleos existentes no estado de São Paulo.

O perfil característico de uma incubadora é o agrupamento de empresas iniciantes, com atuação direta e quase que exclusiva dos proprietários, e atividade voltada ao desenvolvimento de novas tecnologias. A incubadora assume a forma de um canal de 
inovação por agrupar várias pequenas empresas em um mesmo local, com tecnologias que muitas vezes se complementam. A grande vantagem de um canal de inovação é a socialização de recursos essenciais às empresas, através da redução significativa dos custos de instalação e infra-estrutura (sede, fone, fax, administração, marketing, estrutura de vendas, etc.) possibilitando às empresas, a concentração de seus recursos financeiros exclusivamente em seu negócio específico, voltado à inovação.

Alguns consideram o canal de inovação como uma forma híbrida de organização, com potencial para substituir as empresas hierárquicas; outros consideram apenas como uma forma transitória de organização.

Os teóricos franceses focalizam os aspectos geográficos e características regionais de um canal de inovação, conforme teoriza Camagni, R. (1991), enquanto os anglo-saxãos estudam o aspecto sistêmico, conforme Nohria, N. e Eccles, R.G. (1991).

No Brasil, o canal de inovação é visto pelos profissionais envolvidos em sua gestão, como uma forma de alavancar o conhecimento tecnológico, proporcionando ganhos futuros através de exportação e redução da dependência de fornecimento externo de inovações.

Entretanto, há consenso no qual o canal de inovação é mais que uma simples agregação entre empresas, hoje sabe-se que ele cria oportunidades de inovações, conforme estudos de Galaskiewicz, J. (1996). Um canal de inovação pode ser formado por uma série de posições ou nós, constituídos por empresas, unidades de negócios, universidades, governos, consumidores, entre outros, estabelecendo uma conexão entre estes. No caso do Brasil, os canais de inovação são gerados através da iniciativa de prefeituras, universidades e órgãos empresariais, como é o caso do SEBRAE.

A posição da empresa dentro do canal é algo estratégico pois reflete seu poder de influência. Quando há altos custos de aquisição de tecnologia, o canal de inovação aproxima-se de uma rede ao invés de um modelo de mercado, pois começa a agregar instituições financeiras, escritórios comerciais, representantes comerciais, ou seja, todo tipo de atividade não geradora de inovação, mas que começa a se tornar fundamental como infra-estrutura de apoio ao canal. É o caso de uma empresa incubada que necessita da importação de um equipamento sofisticado e de alto custo. $\mathrm{O}$ processo de aquisição certamente envolverá atividades extras canal, que não estão relacionadas ao 
seu objetivo, mas que se tornam fundamentais no processo de aquisição, ampliando a malha de atuação do canal de inovação, fazendo com que assuma o perfil de uma rede.

Os canais apresentam duas características: atividades cíclicas e instabilidade.

A existência de atividade cíclica junto a cadeias transacionais (atividades diversas relacionadas a outras, as quais, através de repetição podem combinar-se formando as cadeias transacionais) pode criar restrições dentro do canal. A repetição das transações é a base da eficiência, mas a interdependência sistemática pode tornar-se uma restrição às mudanças.

O canal de inovação pode assumir dois tipos diferentes, conforme indicado na tabela abaixo:

Tabela 4 : Tipos de canal de inovação.

\begin{tabular}{|l|l|l|}
\cline { 2 - 3 } \multicolumn{1}{c|}{} & \multicolumn{2}{c|}{ Canal de inovação } \\
\hline Características & \multicolumn{1}{|c|}{$\begin{array}{l}\text { Tecnologias diversas. Interfaces e } \\
\text { componentes especiais. }\end{array}$} & $\begin{array}{l}\text { Compatibilidade entre vendas e } \\
\text { produtos. }\end{array}$ \\
\hline $\begin{array}{l}\text { Estratégia } \\
\text { empresarial }\end{array}$ & $\begin{array}{l}\text { Padronização de controles, através } \\
\text { da proteção da propriedade do } \\
\text { conhecimento. }\end{array}$ & $\begin{array}{l}\text { Padronização, com a participação } \\
\text { de conhecimento dos concorrentes } \\
\text { e parceiros de mercado }\end{array}$ \\
\hline Vantagens & $\begin{array}{l}\text { Economia de escala. } \\
\text { Consumidores localizados }\end{array}$ & $\begin{array}{l}\text { Economia de atividades, } \\
\text { múltiplos segmentos. }\end{array}$ \\
\hline
\end{tabular}

Fonte: Adaptado de Garud, R. e Kumaraswamy, A. : Changing competitive dynamics in network industries, Strategic Management Journal, London,1993, 14, pags. 351 a 369

Outros exemplos claros de canais de inovação são a internet, a intranet e a extranet, cujas ramificações e conseqüências estão longe de serem totalmente mapeadas.

Em nosso estudo faremos uma avaliação mais detalhada das incubadoras de São Carlos (ParqTec São Carlos) e São Paulo (dentro do campus da Universidade de São Paulo).

\subsubsection{As principais fontes de inovacão}

Neste parágrafo vamos enumerar as fontes de inovação mais utilizadas. Estes dados estão baseados em pesquisa bibliográfica com autores ingleses e americanos, e retrata dados coletados no mercado brasileiro. 
Além dos aspectos abordados no item 2.6.1 onde enumeramos as principais formas de colaboração, que em si, já constituem uma forma de obter a inovação, vamos destacar outras formas da empresa obter a inovação, que devem ser consideradas devido à importância e difusão das mesmas.

Neste item estaremos enumerando as mais usuais e importantes fontes de inovação, que podem ser acessadas por uma ou mais empresas, independente de acordo ou associação que possa estar ocorrendo. Nossa escolha em colocar estes fontes de inovação à parte ocorre em função de seu caráter independente de alianças ou fusões, podendo ser utilizadas por uma empresa isolada.

Estas fontes de inovação foram destacadas por Tidd, J. e Trewhella, M. (1997) após estudos de caso realizados em 23 empresas da Inglaterra e 15 do Japão, que adquiriram tecnologia de fontes externas.

\subsubsection{Universidades}

É uma das fontes de tecnologia e inovação mais utilizadas no mundo. Possibilita à pequena e média empresa o acesso aos profissionais de nível mestrado, doutorado e pósdoutorado a custos acessíveis. Outra característica importante é o acesso aos conhecimentos científicos mais atualizados, podendo abrir à empresa meios de avanço mais rápido nas áreas de ciência e tecnologia. O exemplo mais característico no Brasil são exatamente as incubadoras de empresas, cujo funcionamento está diretamente atrelado às universidades. Conforme já comentamos, será dada ênfase no levantamento entre empresas incubadas junto aos campi São Paulo e São Carlos da USP.

\subsubsection{Consórcios de Pesquisa}

É a colaboração entre empresas competidoras, ou não competidoras entre si. A colaboração entre empresas competidoras é possível quando está em andamento o desenvolvimento de uma tecnologia pré-competitiva ${ }^{8}$. Com o cumprimento das metas do consórcio, cada empresa começa seu próprio desenvolvimento interno, a partir da inovação desenvolvida pelo consórcio.

\footnotetext{
${ }^{8}$ Seria o caso de empresas competidoras entre si, que participam do desenvolvimento da tecnologia do cristal ferroelétrico líquido.
} 
$\mathrm{Na}$ grande maioria dos casos, o consórcio entre empresas é visto como forma de alavancagem das habilidades internas de uma empresa, funcionando como um complemento à sua capacidade tecnológica.

\subsubsection{Licenciamento}

É muito utilizado, pois permite à empresa que busca a inovação, maior rapidez no acesso às novas áreas tecnológicas que ela ainda não domina.

Existe uma restrição ao licenciamento, devido ao fato deste método de acesso à inovação "padronizar" um produto, ou seja, se duas ou mais empresas licenciam uma mesma inovação, fatalmente seus produtos finais serão muito parecidos, comprometendo a diferenciação destes. Caso o consumidor perceba o fato, isto pode conduzir os concorrentes a uma situação de canibalização de mercado, levando as margens de lucro a índices decrescentes.

Este tipo de acordo somente é viável quando o tipo de tecnologia em questão é facilmente quantificável.

\subsubsection{Clientes e Fornecedores}

É muito comum a colaboração entre empresas clientes e consumidoras. Esta forma de colaboração, denominada parceria é interessante pois estabelece vínculos de credibilidade entre empresas, favorecendo a economia de escala e o planejamento de demandas futuras. É dos métodos de desenvolvimento de inovações mais utilizados no segmento automobilístico.

\subsubsection{Aliancas entre empresas}

É uma forma de acesso à inovação que pode assumir tanto a forma de aquisição entre empresas, quanto a transferência de conhecimento intra-empresas, através do uso compartilhado de áreas de pesquisa e desenvolvimento.

A aquisição é uma forma de acesso à inovação que apresenta alguns riscos, pois envolve toda uma transformação de níveis hierárquicos superiores e alterações de pessoal de desenvolvimento, o que pode acarretar tensões internas, desmotivações ou perda de pessoas chave. O fato motivador de uma aquisição é o conhecimento que a empresa adquirida tem a respeito do mercado voltado à inovação. 
No caso de transferência intra-empresas, o fato motivador é o uso compartilhado de laboratórios centrais ou corporativos de $\mathrm{P} \& \mathrm{D}$, reduzindo significativamente os custos de desenvolvimento e os riscos envolvidos.

A figura abaixo relaciona a importância e a criticidade das diversas fontes de inovação:

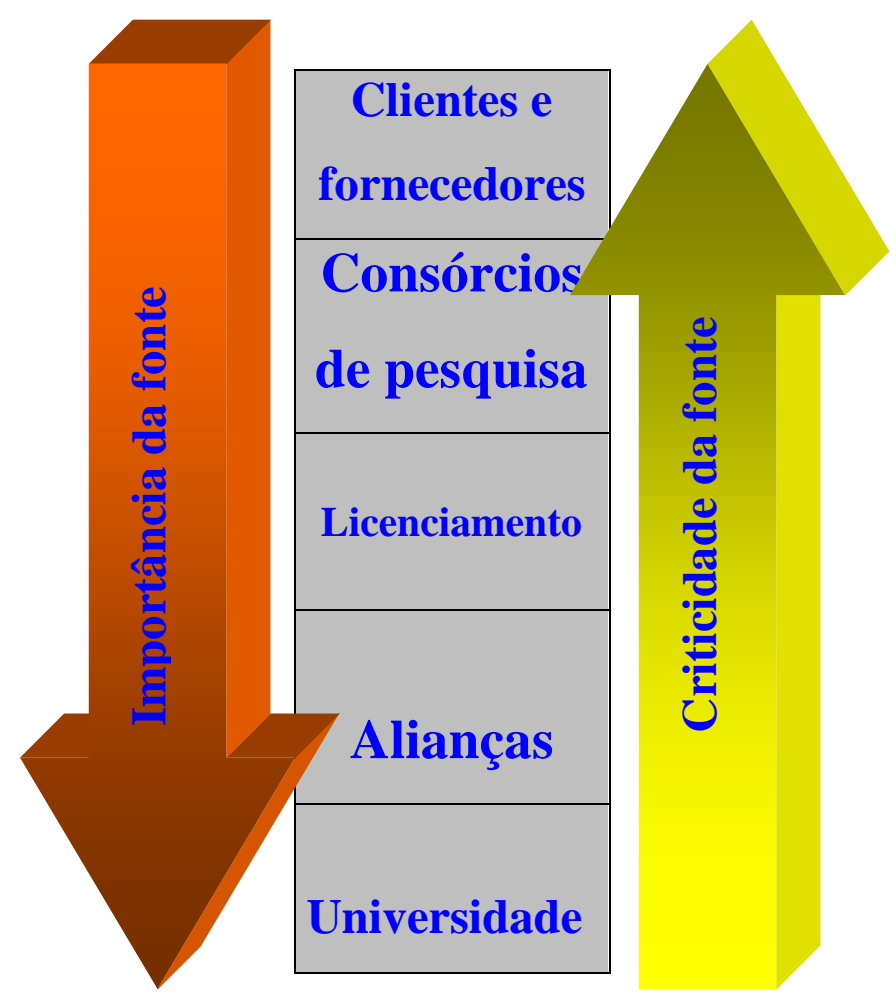

Figura 11: Importância relativa das diversas fontes de inovação

Fonte: Adaptado de Tidd, J. e Trewhella, M.: Organizational and technological antecedents for knowledge acquisition, R\&D Management, London, 1997

\section{$\underline{\text { 2.7 As ferramentas da qualidade e a inovação }}$}

A qualidade desempenha um papel fundamental no processo de inovação de uma empresa. De acordo com Galgano, A.(1993), o desenvolvimento de novos produtos, consequiência do processo de inovação, é a atividade central de um sistema amplo da qualidade (CWQC - Company Wide Quality Control - Controle da Qualidade Amplo Empresarial). Ainda de acordo com Galgano, A.(1993) e de acordo com o que foi comentado anteriormente no Capítulo 2 (item 1.2), o êxito de uma empresa está relacionado à freqüência com que esta leva ao mercado, produtos novos e diversificados. Portanto, é fundamental que a empresa estabeleça um sistema de apoio para a geração de inovações com freqüências cada vez menores e que apresentem os 
níveis de qualidade e confiabilidade exigidos pelo mercado. Um sistema de qualidade amplo e bem estruturado (CWQC ou TQM) fornece os mecanismos mais eficazes para a o êxito do processo de inovação.

Quando falamos de um sistema da qualidade amplo, é claro que estamos nos referindo às ferramentas de análise (diagrama Ishikawa, análise de Pareto, CEP - Controle Estatístico de Processo, entre outras) às análises estatísticas adequadas aos problemas mais complexos (estudos de capacidade de processo, análises de variância, estudos de regressão, delineamento de experimentos, entre outros) bem como aos instrumentos de gestão (diagramas de afinidade, de relação, do tipo árvore, em matriz e diagrama de flechas, entre outros).

Todos estes procedimentos devem estar agregados em forma de um sistema da qualidade, através da gestão por políticas, apoiadas por demais programas e técnicas de duração limitada (programa $5 \mathrm{~S}$, técnica $5 \mathrm{~W} 1 \mathrm{H}$, entre outras) conforme proposto por Galgano, A. (1993) e Merli, G. (1993).

Estes sistemas são fundamentais a todas as empresas, independente de seu porte, segmento ou visão de um processo de inovação. Desse modo, não haveria sentido abordarmos o sistema da qualidade como um instrumento exclusivamente voltado à inovação empresarial.

Alem disso, como nosso universo de análise são as pequenas e médias empresas do segmento eletro eletrônico, estaremos trabalhando com empresas cujo porte pode não justificar a implantação de um sistema da qualidade amplo.

Entretanto, existem ferramentas da qualidade cuja aplicação é de caráter fundamental ao processo de inovação e que foram concebidas exatamente ao processo de transferência tecnológica. Essas ferramentas podem ser utilizadas como uma prática empresarial, independente de um sistema da qualidade em uso. É dessas ferramentas que nos ocuparemos neste parágrafo.

Faremos detalhamento das ferramentas da qualidade essenciais ao processo de inovação, conforme descrito abaixo: 
- Benchmarking - É uma ferramenta essencial à etapa de idealização de um novo produto ou processo. Deve ser utilizada quando o novo produto ou processo estão sendo idealizados.

- QFD - É a ferramenta essencial ao processo de desenvolvimento de um novo produto, cobrindo desde a etapa de pesquisa de marketing até a fase de lançamento do produto.

- Kaizen tecnológico - Prática essencial ao novo produto, quando este já foi lançado ao mercado e está em processo normal de comercialização.

É importante destacar que estas ferramentas apresentam características essencialmente preventivas e voltadas a melhorias de produtos e projetos, e quase nenhuma característica corretiva.

\subsubsection{Benchmarking - (Testes de nível e de desempenho)}

De acordo com a definição de Breyfogle, F.W. (1999), o benchmarking é a busca da organização por práticas melhores, adaptação destas práticas melhores aos seus processos, e a busca de melhorias objetivando tornar-se a melhor empresa dentro de sua categoria.

O benchmarking é um processo comparativo que pode envolver produtos, processos, métodos e estratégias. Ainda de acordo com Breyfogle, F.W. (1999), o benchmarking pode ter 4 classificações diferentes:

- Benchmarking interno: É a comparação de operações similares dentro de uma mesma organização,

- Benchmarking competitivo: É a análise comparativa dos produtos de concorrentes diretos da empresa.

- Benchmarking funcional: É a comparação da metodologia de processos produtivos similares, utilizados pelos concorrentes.

- Benchmarking genérico: É a comparação de processos produtivos de outras empresas, envolvendo inovações tecnológicas ou metodologias diferenciadas. 
As principais fontes de informação para o benchmarking incluem a internet, materiais de publicação interna de uma empresa (quando se trata de grande porte), associações de empresas, universidades, fornecedores, publicidade e pesquisas junto aos clientes.

\subsubsection{DFQ - O Desdobramento da Funcão Qualidade (QFD)}

DFQ é uma ferramenta importante para a inclusão das necessidades do cliente a um novo produto. É aplicada ao processo de inovação por ser uma ferramenta usada para identificar possibilidades de melhorias e diferenciações do produto, ao invés de solucionar problemas já existentes. De acordo com Galgano, A. (1993), o Desdobramento da Função Qualidade é um método concreto para assegurar a qualidade dos novos produtos, desde a fase de projeto e desenvolvimento até a produção e envio ao mercado, ou seja, durante a fase em que a taxa de inovação do produto é mais alta.

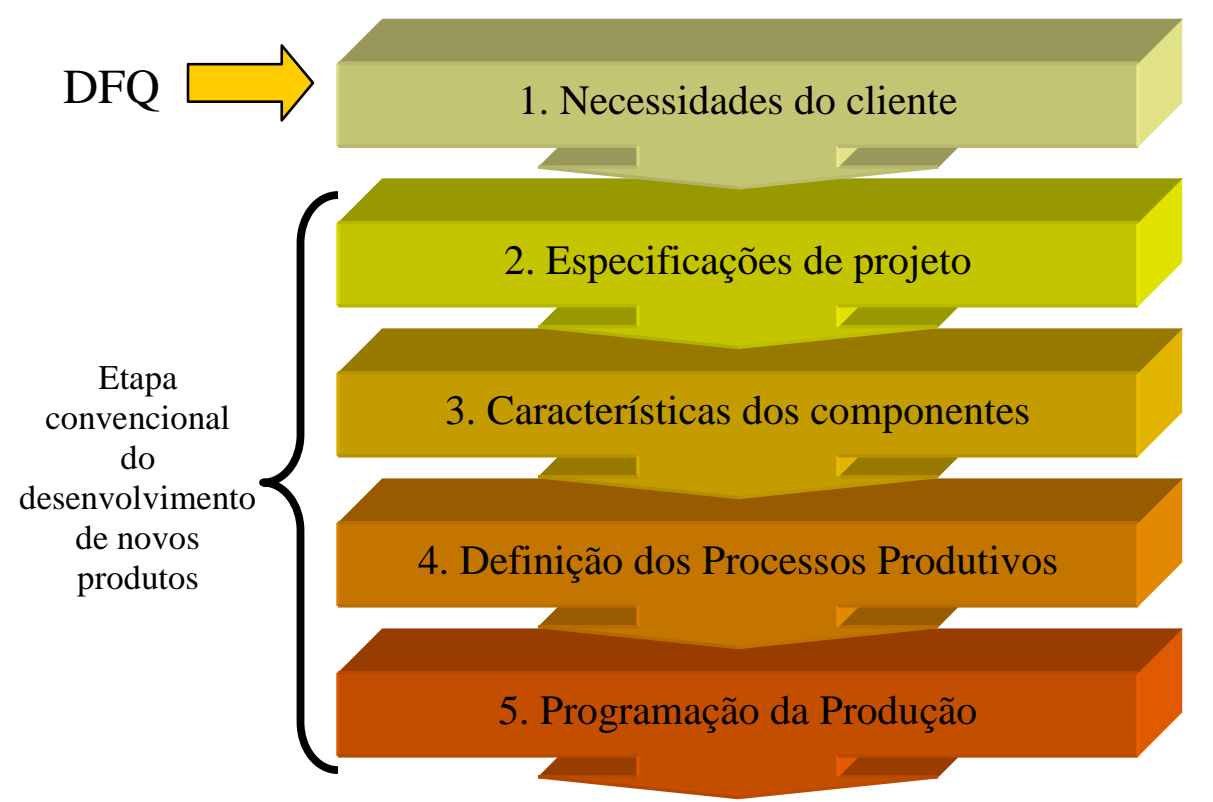

Figura 12 : Princípios do DFQ associados ao desenvolvimento de novos produtos

Fonte: Galgano, Alberto, La Qualitá Totale. Il Company Wide Quality Control come nuovo sistema manageriale, Ediciones Diaz de Santos, S. A., 1993

A etapa número 1 (Necessidades do cliente) corresponde ao princípio fundamental do DFQ e deve ser usado como um levantamento dos itens de inovação passíveis de serem adicionados ao novo produto. 
Um dado importante ressaltado por Galgano, A. (1993) é o aspecto vago das necessidades dos clientes, ou seja, são aspectos qualitativos genéricos, abrangentes e nem sempre específicos. Geralmente a empresa avalia todos os subsistemas e componentes dos novos produtos e processos, mas nem sempre estuda do mesmo modo as necessidades dos clientes, justamente por não serem claros e bem definidos. A finalidade do DFQ é trabalhar-se com os aspectos considerados vagos, relacionados às necessidades dos clientes, possibilitando um processo de inovação com melhor retorno para o produto.

Para um desenvolvimento coerente das atividades de DFQ, a empresa em busca de inovações deve sair do modelo tradicional de desenvolvimento de novos produtos e partir para um procedimento novo, conforme indicado nas figuras a seguir:

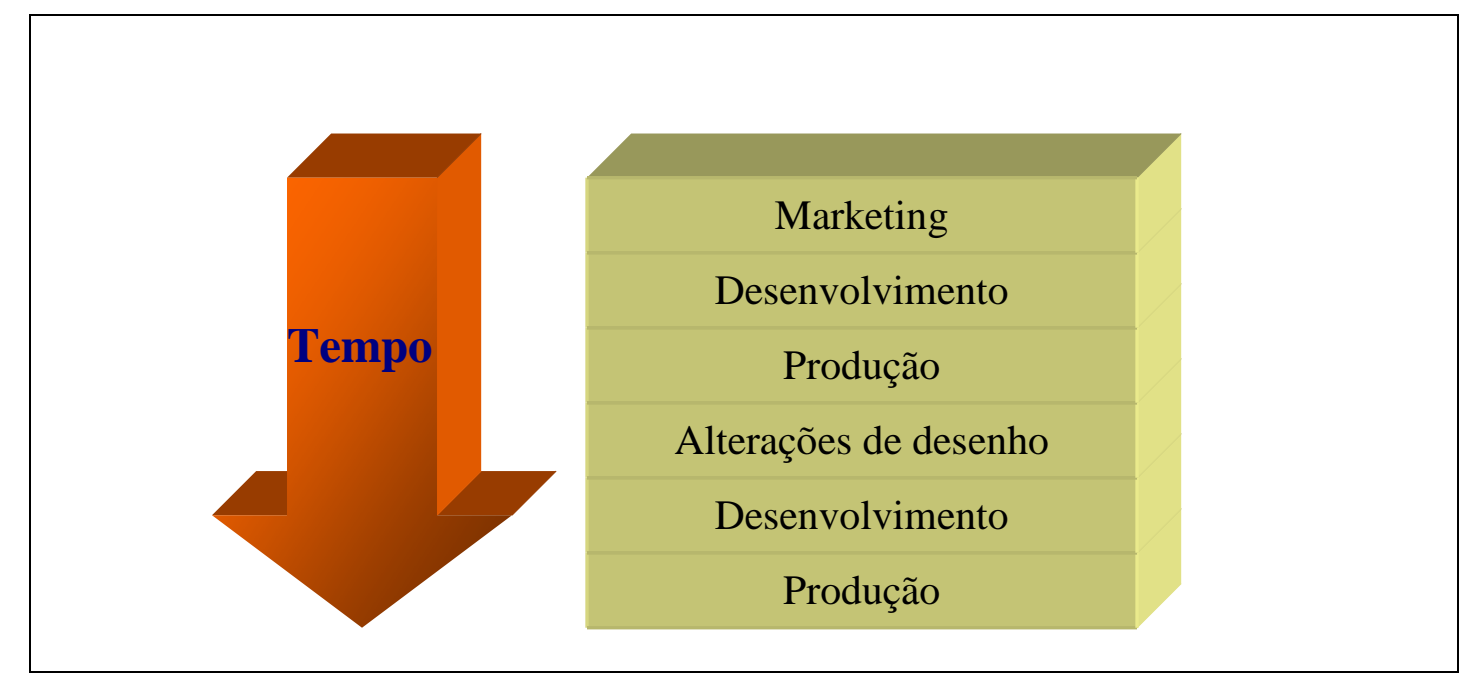

Figura 13: Método tradicional de desenvolvimento de um novo produto

O método otimizado (com o uso do DFQ) propõe é a participação conjunta das áreas de Marketing, Planejamento e Produção, desde a fase de concepção do produto até a plena produção. 


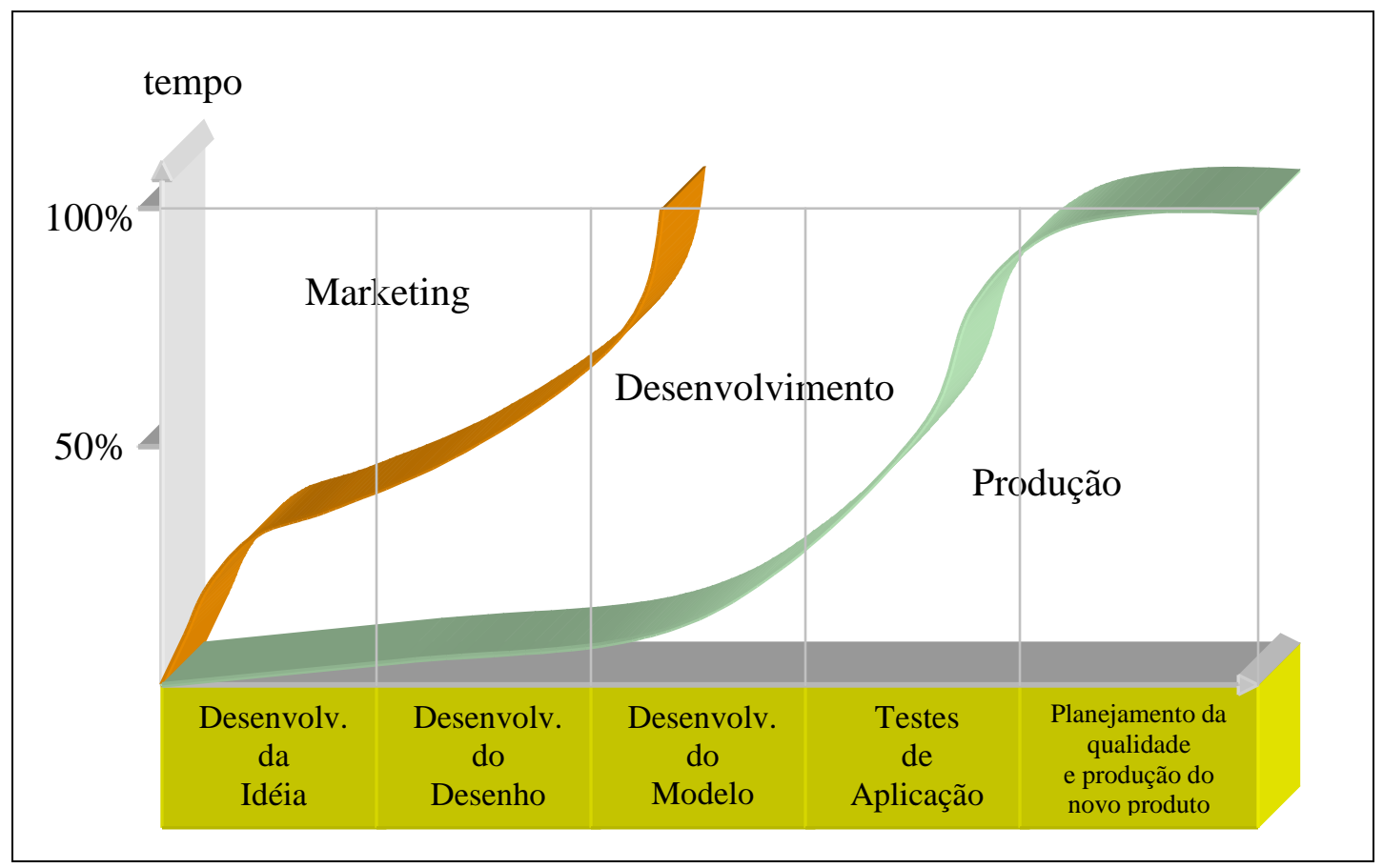

Figura 14: Método otimizado para desenvolvimento de um novo produto - DFQ.

Fonte: Galgano, Alberto, La Qualitá Totale. Il Company Wide Quality Control come nuovo sistema manageriale, Ediciones Diaz de Santos, S. A., 1993

Conforme Tidd, J. et alii (1997), o DFQ é constituído por dados técnicos e de marketing, exigindo a participação conjunta das áreas de Marketing, Desenvolvimento e Produção ${ }^{9}$. A estrutura do DFQ é formada por uma lista de atividades básicas e por um conjunto de técnicas e instrumentos, conforme veremos a seguir.

\subsubsection{O Processo de DFQ}

A aplicação da ferramenta DFQ possibilita a determinação das exigências dos clientes com maior clareza (conforme já mencionamos, trabalha com os aspectos "vagos"), fazendo com que as informações solicitadas sejam traduzidas ou "desdobradas", gerando inovações mais eficazes.

\footnotetext{
${ }^{9}$ A ferramenta DFQ surgiu originalmente na Toyota, onde proporcionou redução de custos e de tempo de desenvolvimento da ordem de 40\%. Entretanto, de acordo com Griffin, A. (1992), empresas americanas como AT\&T, Ford e Digital passaram a utilizar esta ferramenta mais recentemente, porém apenas $25 \%$ delas apresentaram benefícios quantificáveis. De acordo com o mesmo autor, a aplicação desta ferramenta em empresas européias tem sido mais restrita, devido a problemas na prática de implantação.
} 
A matriz da qualidade, indicada abaixo estabelece as relações entre o conhecimento técnico e de mercado, possibilitando a otimização do processo de inovação do produto.

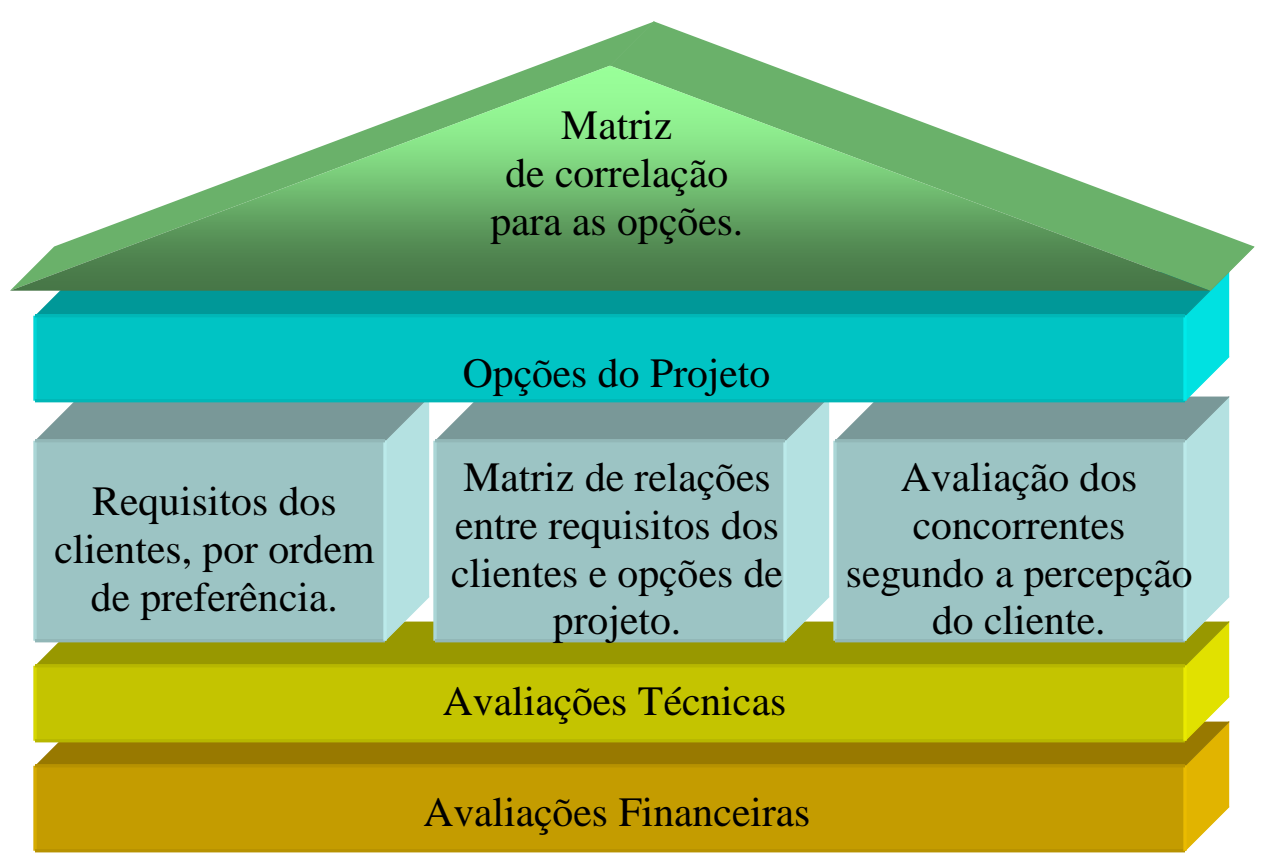

Figura 15: Matriz do Desdobramento da Função Qualidade - Casa da Qualidade

Fonte: Tidd, Joe et alii, Managing Innovation: Integranting Technological, Market and Organizational Change, John Willey \& Sons, London, England, 1997.

A construção da matriz DFQ é feita como segue:

1. Identificar os requisitos do cliente, primários e secundários, e as insatisfações.

2. Classificar os requisitos de acordo com sua importância.

3. Transformar os requisitos em características mensuráveis.

4. Estabelecer a relação entre os requisitos do cliente e as características técnicas do produto, estimando-se o peso (importância) desta relação.

5. Determinar as unidades de medidas apropriadas e determinar os valores objetivos baseados nos requisitos dos clientes e no benchmark genérico (vide 2.7.1 Benchmarking), em relação aos concorrentes.

Há situações em que o cliente tem necessidades latentes, que não conseguem articular. Neste caso classifica-se a necessidade do usuário em três categorias: "deve ser", "unidimensional" e "plenamente satisfatória" .

- A “deve ser" são as características que devem estar presentes no produto. 
- A "unidimensional" é o conjunto de características mais quantitativas, de comparação direta com os concorrentes.

- A "plenamente satisfatória" é o conjunto de características mais sutis na diferenciação.

A inclusão destas características ao produto atende plenamente ao cliente, ainda que este não tenha explicitado esta necessidade.

\subsubsection{Os possíveis resultados da aplicacão do DFQ}

De acordo com Galgano, A. (1993) é possível quantificar-se benefícios ao longo das diversas fases do processo de inovação, conforme segue:

\section{Benefícios relacionados à fase anterior ao lançamento do novo produto.}

- Compreensão das necessidades e características mais esperadas pelos clientes; eliminação das inovações de pequeno impacto de mercado.

- Redução do lead time, enriquecimento do projeto, e redução do tempo de desenvolvimento dos produtos.

- Redução dos custos de desenvolvimento. Racionalização dos recursos.

- Aumento da velocidade das intervenções no projeto. O planejamento do projeto e as prioridades são verificados mais cedo, reduzindo-se a possibilidade de erros.

\section{Benefícios ligados à fase de lançamento.}

- Redução dos erros de lançamento. Os produtos exigirão menos modificações.

- Redução dos custos de lançamento. O planejamento e os testes da primeira fase resultam em custos menores.

- Melhoria da qualidade do produto.

- Aumento da produtividade. Como os problemas na fase de projeto são reduzidos, isto se traduz em utilização mais racional dos recursos e instalações.

- Melhoria de comunicação. A ferramenta DFQ estimula a integração entre as diversas áreas da empresa. 


\section{Benefícios ligados à fase imediatamente posterior ao lançamento.}

- Redução de falhas de campo e dos custos de garantia.

- Aumento da satisfação do cliente.

- Continuidade do know how . As informações obtidas através da aplicação da ferramenta DFQ são cumulativas e úteis ao desenvolvimento de novos produtos subseqüentes.

\subsubsection{Kaizen tecnológico}

Genericamente podemos definir o kaizen como uma prática de melhoria contínua aplicada a todas as atividades da empresa. É uma dimensão adicional da melhoria da qualidade, surgida dentro da indústria japonesa. Sua aplicação é feita por todos os colaboradores da empresa, não se restringindo às pessoas da qualidade.

Desse modo, sua aplicação ocorre somente após amplos programas de conscientização e treinamento.

A principal característica do processo kaizen é a melhoria lenta, gradual e permanente, aplicada aos processos, produtos e serviços. Ele é o oposto do processo denominado kairyo, que significa mudança brusca, de grande porte e pouco freqüente.

A fim de classificar melhor estes termos, citamos os dois exemplos abaixo:

- Kairyo: Pode ser obtido através da compra de um novo equipamento produtivo, mais moderno e eficiente. Isto pode representar uma melhoria brusca, de grande porte, porém não freqüente. Uma empresa não troca seus equipamentos com grande freqüência devido aos altos custos envolvidos.

- Kaizen: Pode ser exemplificado por pequenas mudanças de processo, ou pequenas alterações efetuadas sobre um produto ao longo de sua vida. São pequenas alterações, graduais e frequientes, que agregam qualidade a um produto ou processo. A importância estratégica do kaizen, de acordo com Galgano, A. (1993) é que as melhorias de pequeno porte, gradativas e freqüentes, aplicadas ao longo da vida de um produto, proporcionam um salto tecnológico equivalente ao salto proporcionado pela 
própria inovação que originou este produto $^{10}$. Esta constatação foi declarada pela empresa americana de telefonia AT\&T, conforme citação de Galgano, A. (1993).

Podemos ainda caracterizar o kaizen como uma seqüência progressiva de pequenos ciclos PDCA aplicados a produtos ou processos, conforme esquematizado abaixo:

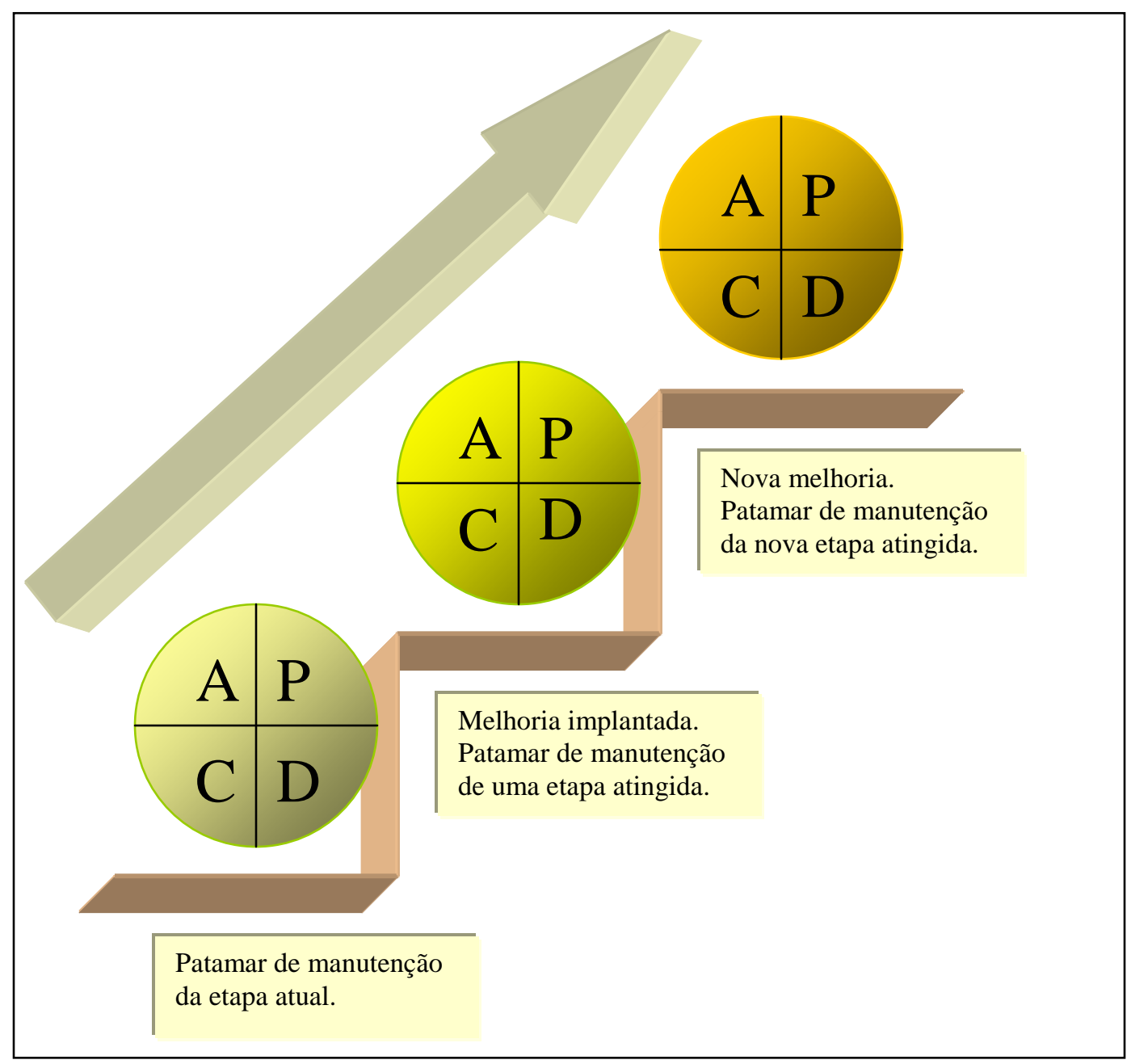

Figura 16: O kaizen esquematizado como uma seqüiência de ciclos PDCA.

Fonte: Galgano, A.: La Qualitá Totale. Il Company Wide Quality Control come nuovo sistema manageriale, Ediciones Diaz de Santos, Madrid, Espanha, 1993

São identificadas 4 diferentes formas de kaizen:

\footnotetext{
${ }^{10}$ Podemos caracterizar isto através do produto "forno de microondas". Se imaginarmos os primeiros fornos de microondas, extremamente grandes, com a área interna reduzida, controle de tempos através de seletor giratório e prato interno estático, e compará-los aos fornos atuais, de menores dimensões externas, com teclado para controle eletrônico de tempos, pratos giratórios em dois níveis (dois andares) e recursos que permitem dourar um alimento e torná-lo crocante (entre outros recursos), verificamos que estas mudanças gradativas (ocorridas ao longo de aproximadamente uma década) correspondem a um salto tecnológico equivalente ao surgimento dos primeiros fornos de microondas.
} 
- Kaizen de processo;

- Kaizen de tempo;

- Kaizen de mão de obra;

- Kaizen tecnológico.

Os três primeiros tipos de kaizen são de aplicação típica à situação "em curso" dentro de uma empresa. Entretanto, o kaizen tecnológico apresenta uma adequação muito grande aos processos de inovação, especialmente nos setores de eletroeletrônica, conforme citado por Galgano, A. (1993), na página 179.

Sendo um processo (e não uma ferramenta), dependerá de um monitoramento e conscientização constantes, para que haja participação de todos os envolvidos. Neste caso, como se trata de um produto em fase imediatamente pós-lançamento em mercado, a participação dos profissionais das áreas da Qualidade e Desenvolvimento serão maiores. Esta fase gera novas idéias e novas tecnologias aplicáveis aos futuros novos produtos da empresa.

$\mathrm{Na}$ aplicação do kaizen tecnológico, os profissionais devem voltar suas atenções à busca de quatro aspectos fundamentais para a evolução de um novo produto, resultante de uma inovação:

- Miniaturização do produto, com a conseqüente redução de custo e evolução do conceito do produto;

- Simplificação do projeto, reduzindo a quantidade e variedade de componentes, reduzindo custos e otimizando o processo de produção;

- Visualização, ou melhoria do visual do produto, tornando-o mais atrativo ao consumidor;

- Transformação ou readaptação das partes ou sub conjuntos do produto, o que favorece a possibilidade de chegar-se a outros novos produtos, totalmente distintos do produto inicial. 


\subsection{Dinâmica da inovação - Como ela se processa.}

Existe um padrão de desenvolvimento da inovação? Ou seja, existe uma dinâmica da inovação? E ainda, é possível dominar essa dinâmica de modo a serem previstas e quantificadas as variáveis envolvidas nesse processo, diminuindo-se os riscos inerentes à inovação, citados nos capítulos anteriores?

De fato, há um modelo de dinâmica da inovação, proposto por Utterback, J. M. (1996), que propõe um modo de monitoramento deste processo.

O modelo proposto pelo autor está focado no conjunto de inovações e evoluções de um segmento industrial completo, correspondente a um produto. O foco principal não está na inovação do produto em si mesmo, mas na inovação contextualizada do produto no cenário histórico do segmento industrial onde ele está inserido.

Nesta perspectiva, aborda a evolução de um produto através do conjunto de inovações, dentro do seu segmento industrial, englobando todo o grupo de empresas desse segmento, envolvidas com este mesmo produto ou família de produtos.

Dentro dessa ótica, Utterback estabelece o "projeto dominante" ou "inovação dominante", este sim, caracterizado como uma inovação significativa e de grande impacto mercadológico.

\subsubsection{A dinâmica da inovação e o mercado.}

Utterback, J. (1996) propôs um modelo da dinâmica da inovação baseado na hipótese de que os produtos e os processos seguem um padrão geral ao longo do tempo. A figura abaixo representa esse modelo, considerando as relações entre as inovações dos produtos e processos ao longo de três fases distintas: 


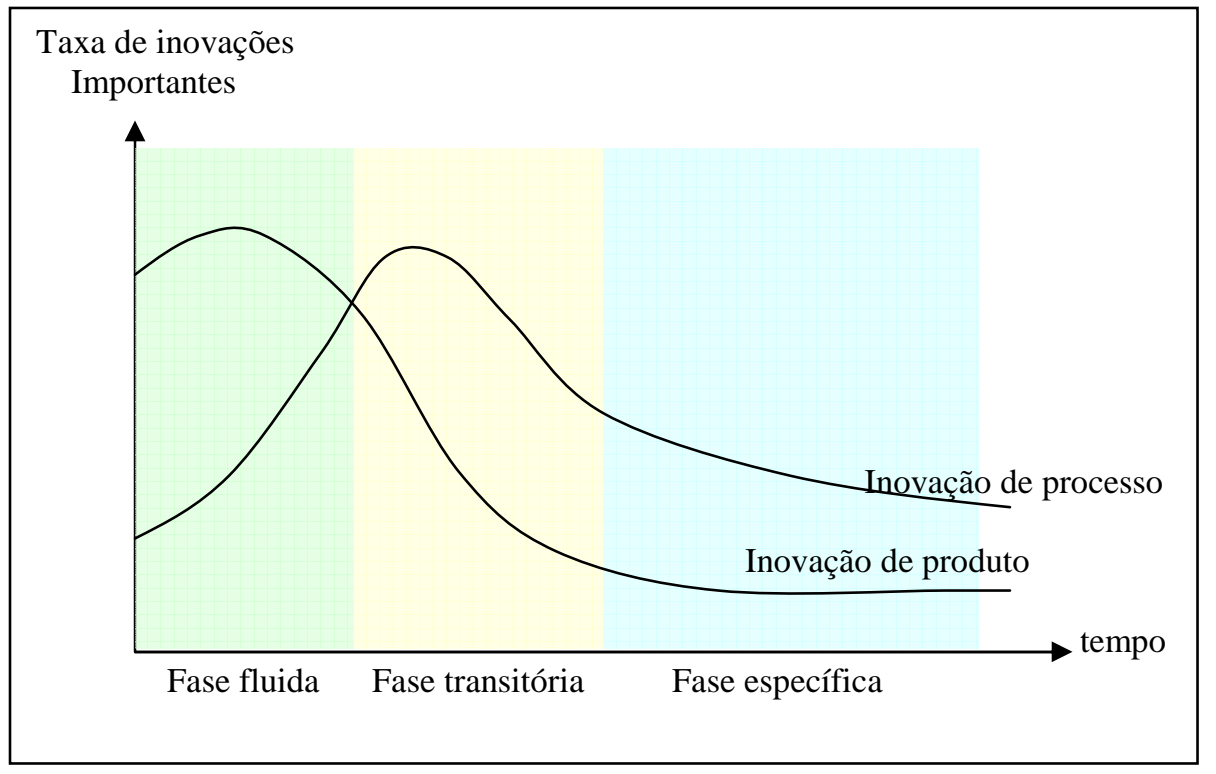

Figura 17: Modelo da dinâmica da inovação na indústria

Fonte: Utterback, J.M.: Dominando a Dinâmica da Inovação. Editora Qualitymark, Rio de Janeiro, 1996.

As fases ao longo das quais se processam as inovações de produto e processo são classificadas como:

Fase fluida, onde a taxa de inovações verificada é a mais alta. Nesta fase o projeto do produto passa por varias revisões, até apresentar a maioria das características esperadas pelo mercado.

Fase transitória, caracterizada pela redução do número de inovações no produto e aumento do número de inovações no processo. Nesta fase começam a surgir os projetos padronizados, adequados às exigências dos clientes. $\mathrm{O}$ enfoque passa a ser o processo produtivo, buscando-se o menor custo e o menor tempo de processamento.

Fase específica, caracterizada pela redução da taxa de inovações tanto no produto quanto no processo. Nesse momento, o foco é a redução de custo do produto e do processo. 
Estas três fases são definidas pelo autor para um segmento industrial completo, envolvendo todos os fabricantes de um determinado produto. Embora a abordagem feita no item 2.2.1 - O ciclo de vida do produto e a freqüência da inovação descreva um processo individual, restrito a um produto ou a uma família de produtos, sob a ótica de um fabricante, a mesma apresenta um paralelo absoluto com a visão de Utterback.

A partir deste modelo Utterback propõe ainda o estabelecimento de um padrão de evolução industrial, baseado na relação entre a taxa de inovações e a concorrência: ao crescimento da taxa de inovações associa-se o aumento gradativo do número de empresas integrantes de um determinado segmento industrial. . Assim, ao impor uma nova tecnologia, a dinâmica da inovação determina uma explosão de concorrentes, que só é rompida na ocorrência do "projeto dominante", denominado também de "inovação dominante".

O autor apresenta vários exemplos, todos caracterizados pela explosão de concorrentes seguida da implosão de mercado, quando a grande maioria destes desaparece. Os exemplos coletados pelo autor sugerem a existência de um padrão de comportamento do mercado.

\subsubsection{A Inovação Dominante.}

De acordo com Utterback, o "projeto dominante" é a inovação que estabelece a forma definitiva de um produto, é a versão que adquire a fidelidade do mercado. Quando é estabelecida essa inovação dominante, todos os concorrentes devem adotá-la, sob o risco de desaparecerem do mercado. A inovação dominante estabelece um novo produto, um conjunto de novas características, novos processos, ou um novo rumo para os produtos já existentes.

Utterback, J. identificou vários exemplos que demonstram essa dinâmica, nos segmentos automobilístico, de calculadoras científicas, de televisores, entre outros. A seguir, veremos o exemplo do segmento automobilístico:

A indústria automobilística passou por uma fase de grandes e freqüentes inovações em seu estágio inicial, entre o final do século XIX e início do século XX (sua fase fluida) 
até atingir a fase transitória entre os anos 20 e 30, atingindo a fase específica no final dos anos 60, desse mesmo século.

De acordo com a análise de Utterback, J., entre 1894 e 1918 surgiram 60 fabricantes de automóveis nos EUA. Em 1923 já eram 75 fabricantes diferentes. Porém, em 1925, a Dodge lançou o automóvel com carroceria fechada e totalmente em aço, substituindo as carrocerias abertas feitas de alumínio e madeira, introduzindo de modo involuntário, a inovação dominante. $\mathrm{O}$ novo conceito causou a implosão do segmento industrial com a drástica redução da quantidade de fabricantes, impondo o conceito do automóvel conforme é fabricado até hoje. O gráfico a seguir mostra essa evolução histórica:

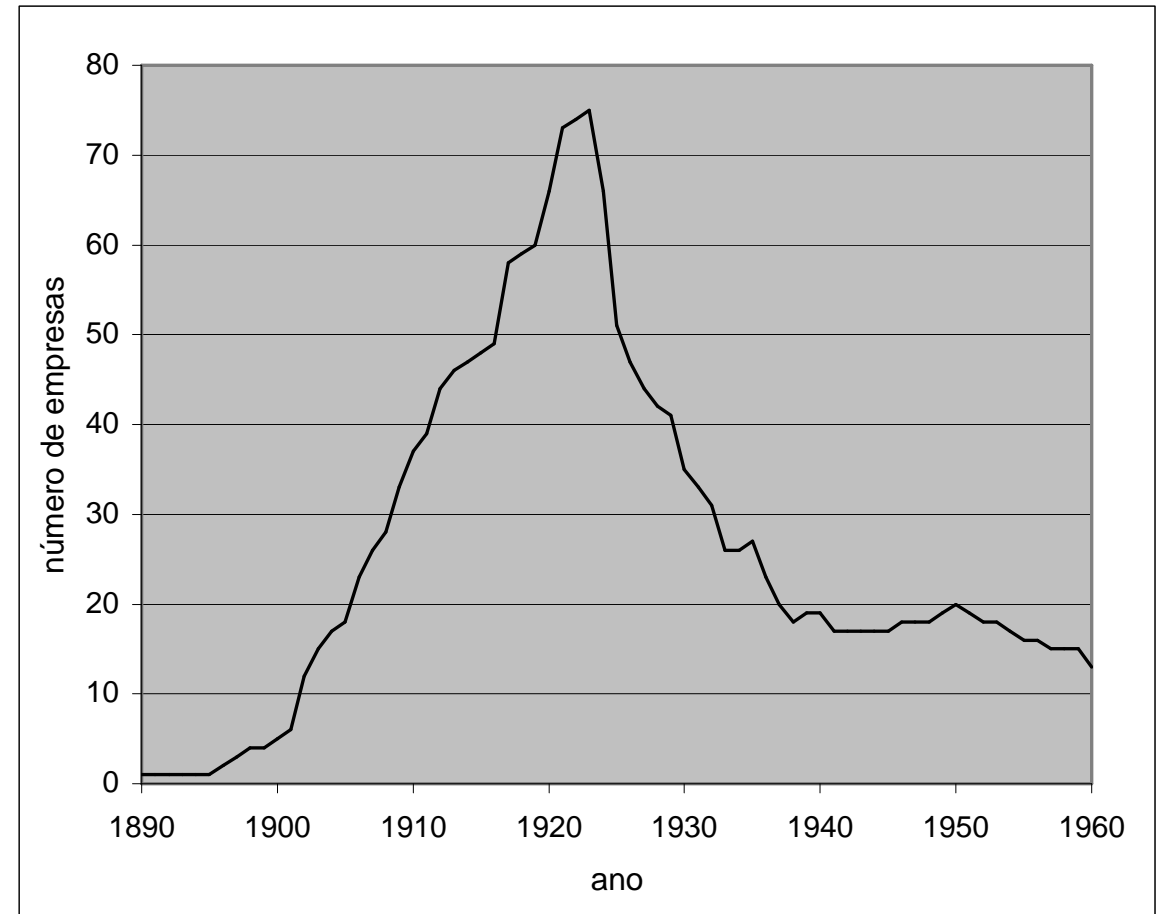

Figura 18: Número de empresas automobilísticas em operação nos EUA.

Fonte: James M. Utterback, Dominando a Dinâmica da Inovação. Editora Qualitymark, Rio de Janeiro, 1996.

\subsubsection{A inovação dominante pode ser identificada?}

Seria ideal se toda inovação dominante fosse imediatamente identificada, sinalizando ao administrador empresarial as mudanças importantes ainda na fase inicial.

Existem três linhas de pensamento que procuram identificar a inovação dominante: 
- A primeira linha parte do princípio no qual as inovações dominantes resultam de eventos aleatórios, cujo aparecimento não pode ser previsto.

- A segunda linha trabalha com um ponto de vista determinístico, ou seja, a observação de dados associados à tecnologia pode conduzir a uma ou algumas inovações determinantes. $O$ enfoque desta linha de pensamento está na tecnologia.

- A terceira linha de pensamento parte do princípio no qual fatores sociais e organizacionais determinam a inovação dominante.

Conforme vimos no item anterior, a Dodge introduziu a inovação dominante no segmento automobilístico, ao lançar seus veículos em carroceria fechada e totalmente em aço. A mudança foi efetuada por questões financeiras, pois o preço do alumínio, na época, tornava vantajosa sua substituição pelo aço. O objetivo principal era a redução de custo. Desse modo, o enfoque dessa inovação foi social e organizacional.

Como podemos notar, a identificação de uma inovação dominante não é um processo determinístico, matematicamente exato. Do mesmo modo, nenhuma das três linhas de pensamento é totalmente certa ou totalmente errada. Todas contribuem para a avaliação técnica. Entretanto, a prática tem indicado que a identificação da inovação dominante é feita por retrospecto, ou seja, após a sua ocorrência. Sendo assim, quanto mais imediata a identificação, após sua ocorrência, maior a vantagem competitiva para a empresa que está inserida no segmento industrial em questão.

Os dados mais comumente associados às inovações dominantes são a simplicidade de projeto e a elegância tecnológica, esta, associada ao desenho do produto.

De acordo com o autor, no caso dos produtos "montados", ou seja, resultantes de processamento industrial, a inovação dominante ocorre no período em que a taxa de inovação do produto cai enquanto a taxa de inovação de processo começa a subir, isto é, entre a fase fluida e a fase transitória. 


\section{Capítulo 3 - Metodologia}

Apesar da forte relação entre inovação tecnológica e vantagem competitiva de uma empresa, conforme discutimos no capítulo 2, não temos uma análise mais profunda desse fenômeno dentro da indústria brasileira. Conforme Terra, J.C.C. (1999), não há estudos mais detalhados sobre esse assunto, aspecto que foi salientado em sua tese de doutorado, abordando a "Gestão do Conhecimento".

Entretanto, alguns dados começam a ser esboçados. De acordo com dados da FIESP, as inovações tecnológicas chegam a representar $40 \%$ das vendas de alguns setores, sem entretanto apresentar dados definidos por segmento industrial. Mesmo assim, a consciência a respeito da relação inovação - competitividade parece estar começando a firmar-se na visão do empresário nacional.

Dados mais recentes a respeito da relação "Dispêndio em P\&D e PIB" mostram que o Brasil apresentou um salto em relação aos dados divulgados pelo último relatório do MCT - Ministério da Ciência e Tecnologia. De acordo com dados do próprio MCT, atualizados após a última publicação do seu relatório correspondente ao período 90/96, o percentual correspondente a P\&D saiu do patamar dos 0,7\% (vide 2.5.1.2, Figura 7) para um patamar de $1,15 \%$, apesar da média dos países desenvolvidos ter passado para 2,5\% de seus respectivos PIB’s, no mesmo período. Comparando-se os dados, verificamos que esta diferença representa uma defasagem de $54 \%$ nos percentuais de investimento, o que indica um avanço em relação à defasagem de $75 \%$ observada no período de 95/96 (vide página 27). Mas, a defasagem ainda é significativa.

Conforme o depoimento da pesquisadora Eva Stal (integrante da Coordenadoria Executiva de Cooperação Universitária - USP) visto no item 1.2 Justificativa, a pesquisa nacional apresenta crescimentos significativos, porém fortemente concentrados entre as grandes empresas sediadas no país. Confirmando sua visão, Roberto Sbragia da Associação Nacional de Pesquisa e Desenvolvimento de Empresas Industriais - ANPEI, afirma que há um grande esforço para investimento em equipamentos e laboratórios, porém, por parte das grandes empresas. Ao mesmo tempo, o engenheiro Sílvio Manrici, diretor da Fundação de Apoio Institucional ao Desenvolvimento Científico e 
Tecnológico da UFSCar, afirma que o acesso das empresas às pesquisas desenvolvidas nas universidades ainda está aquém do ideal.

Este cenário típico da Pequena e Média Empresa é essencialmente oriundo das características básicas dessas próprias empresas, que conforme José Mindlin, presidente de uma das Comissões do Conselho Nacional de Ciência e Tecnologia, geram seus próprios entraves à inovação tecnológica que conduz à competitividade, devido suas visões incompletas quanto à importância da inovação, buscam resultados imediatos e concentram seus esforços quase que exclusivamente em sua própria sobrevivência, comprometendo a visão de futuro.

\subsection{Finalidade da Pesquisa.}

Através do cenário indicado acima, verificamos que a pequena e média empresa encontra-se frente a uma situação crítica no que se refere à realidade tecnológica do mundo atual, e ainda distante das fontes tecnológicas disponíveis. A finalidade desta pesquisa é:

- gerar dados referentes ao processo de inovação tecnológica nas pequenas e médias empresas, procurando ampliar a base de conhecimento para novos estudos.

- Identificar o conhecimento das pequenas e médias empresas a respeito das fontes de inovação.

- Identificar a visão das pequenas e médias empresas quanto a fusões e parcerias tecnológicas.

- Identificar o nível de conhecimento das pequenas e médias empresas quanto às técnicas mais usuais para o desenvolvimento e implementação de novos produtos (QFD, Benchmarking, entre outras).

\subsection{Os modelos de pesquisa científica.}

De acordo com Gil, A.C. (1996) podemos classificar as pesquisas em três modelos básicos: 


\subsubsection{Pesquisas Exploratórias.}

O objetivo destas pesquisas é proporcionar maior familiaridade com um problema, a fim de torná-lo mais claro ou para construir uma hipótese. De acordo com o autor, este tipo de pesquisa tem como objetivo principal o aprimoramento de idéias e ou a descoberta de intuições. Seu planejamento é flexível de modo a poder considerar os mais variados aspectos do fato em estudo.

Esse tipo de pesquisa geralmente envolve:

- Levantamento bibliográfico,

- Entrevistas com pessoas que tiveram experiências práticas com o assunto,

- Analises de exemplos para a melhor compreensão.

$\mathrm{Na}$ maioria dos casos, a pesquisa exploratória assume a forma de pesquisa bibliográfica ou estudo de caso.

\subsubsection{Pesquisas Descritivas.}

A finalidade principal é a descrição de características de uma determinada população ou fenômeno, ou o estabelecimento de relações entre variáveis. Uma de suas características mais marcantes é a utilização de técnicas padronizadas para coleta de dados, tais como questionários e observação sistemática.

Como exemplo de Pesquisa Descritiva, podemos citar aquelas cujo objetivo é estudar a característica de um grupo: idade, sexo, procedência, escolaridade, condições de habitação, etc. Neste tipo de pesquisa incluímos as pesquisas de opiniões, crenças e atitudes de uma população e as pesquisas que procuram estabelecer relações entre variáveis, tais como, preferência político partidária e escolaridade, ou inovação tecnológica de uma empresa e seu desempenho de mercado.

Algumas pesquisas descritivas buscam a relação entre as variáveis analisadas e a natureza desta relação. Neste caso, a pesquisa descritiva aproxima-se da pesquisa explicativa (indicada a seguir). Quando as pesquisas descritivas procuram dar uma visão maior de um problema, aproximam-se da exploratória. Este tipo de pesquisa geralmente assume a forma de um Levantamento ou Survey.

\subsubsection{Pesquisas Explicativas}

Buscam identificar fatores que determinam ou contribuem para a ocorrência de fenômenos. Ela aprofunda o conhecimento da realidade, explicando a razão e o porque 
das coisas. É a pesquisa de caráter mais crítico porque há grande risco de se cometer erros, entretanto, é a pesquisa que fornece o conhecimento científico. Quando se trabalha em ciências naturais, utiliza-se o método experimental na pesquisa explicativa. Seu uso é muito restrito em estudos sociais. A maioria das pesquisas desse grupo é do tipo experimental ou ex-post-facto.

\subsection{A Abordagem de uma pesquisa.}

De acordo com Bryman, A. (1989) uma pesquisa pode ser enquadrada em duas abordagens principais:

\subsubsection{Pesquisa com Abordagem Quantitativa.}

O ponto inicial desse tipo de pesquisa é a teoria que explica um fenômeno da realidade. A partir dessa teoria, uma ou mais hipóteses são formuladas e testadas através de coleta de dados quantitativos, os quais serão analisados para que seus resultados comprovem ou não a teoria. De acordo com Bryman, A. (1989) os aspectos fundamentais desse tipo de pesquisa são:

- A hipótese deve permitir a mensuração de seus conceitos por variáveis, as quais serão trabalhadas através de ferramentas estatísticas.

- A hipótese deve trabalhar sobre uma relação causa e efeito do fenômeno em estudo.

- Procura-se a generalização dos resultados para além dos limites da investigação.

- Procura-se fazer com que os resultados sejam replicáveis, ou seja, possam ser repetidos por outros pesquisadores.

- A tendência é utilizar-se uma única fonte de dados.

- Permite um trabalho à distância por parte do pesquisador.

A figura a seguir indica a estrutura de uma pesquisa com abordagem quantitativa: 


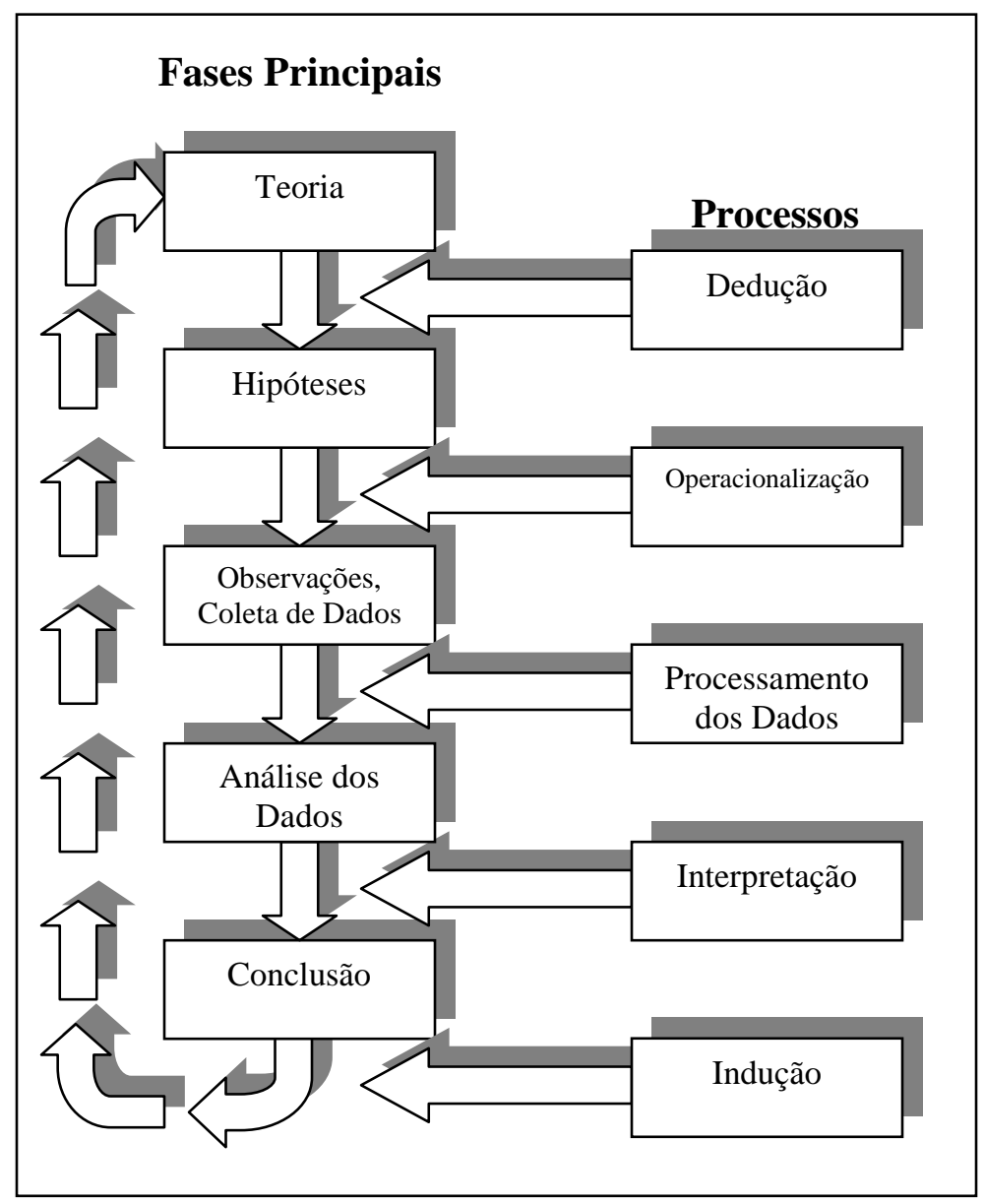

Figura 19: Estrutura de uma Pesquisa Quantitativa.

Fonte: Bryman, A. (1989)

\subsubsection{Pesquisa com Abordagem Qualitativa.}

Este tipo de pesquisa, também denominada interpretativa, busca essencialmente a interpretação de fatos. Nesse tipo de pesquisa, o pesquisador não é a fonte daquilo que é relevante ou importante. Os fatos importantes serão obtidos a partir do objeto da pesquisa. Entretanto, vale lembrar que uma pesquisa qualitativa é feita através da coleta de material quantitativo observado em suas investigações. Desse modo, podemos concluir que uma pesquisa qualitativa não é oposta a uma pesquisa quantitativa, nem trabalha com a ausência de quantificação. Outras características importantes da pesquisa qualitativa são:

- Ela se apóia em métodos estatísticos e quantitativos também.

- Dá maior ênfase na interpretação dos dados, sem, entretanto deixar de elaborar a operacionalização dos dados coletados. 


\subsection{A classificacão das Pesquisas.}

De acordo com Gil, A.C. (1996) as pesquisas são classificadas do seguinte modo:

\subsubsection{Pesquisa Bibliográfica.}

É desenvolvida sobre material já elaborado, essencialmente livros de leitura corrente e livros referência, artigos científicos, publicações periódicas tais como jornais e revistas e impressos diversos. Os estudos exploratórios são enquadrados na classificação de pesquisa bibliográfica.

\subsubsection{Pesquisa Documental.}

É uma pesquisa baseada na análise de materiais que ainda não receberam tratamento analítico. A característica do material de análise é o que diferencia a Pesquisa Documental da Pesquisa Bibliográfica, pois a Bibliográfica utiliza-se de um material já elaborado e trabalhado por diversos autores. É o caso da pesquisa efetuada sobre arquivos e documentos de órgãos públicos, fundações, sindicatos, etc.

\subsubsection{Pesquisa Experimental.}

É o caso da pesquisa científica pura. Ao determinar-se um objeto de estudo, é feita a pesquisa experimental selecionando-se todas as variáveis capazes de influenciá-lo, definindo-se as formas de controle e a observação dos efeitos que cada variável produz no objeto.

\subsubsection{Pesquisa ex-post-facto.}

É a análise de experimentos após a ocorrência de fatos. Não é um experimento porque o pesquisador não controla as variáveis, apenas as analisa, porém os procedimentos adotados são muito parecidos com os de um experimento propriamente dito. È o caso, por exemplo, de duas empresas com características muito semelhantes, número de funcionários aproximado e produtos de mesma natureza. Sobre uma delas aplica-se um modelo de gestão de processo, que gera uma diferença significativa entre elas. A pesquisa ex-post-facto é feita para avaliarem-se as conseqüências dessa modificação. Os fatos observados são espontâneos, não sofrem qualquer influência do pesquisador. 


\subsubsection{Survey (Levantamento).}

É a pesquisa onde ocorre a interrogação direta das pessoas cujo perfil se quer analisar. Procede-se ao levantamento das informações de um grupo significativo de pessoas relacionadas a um determinado tipo de fenômeno que se quer avaliar. Quando o levantamento é abrangente, temos um censo. Entretanto, a execução de um senso envolve recursos materiais e financeiros muito vultosos, o que torna este tipo de estudo, nessa abrangência, somente possível para governos ou instituições de grande porte.

O Survey (Levantamento) é feito sobre uma amostra dos integrantes de uma determinada população que se quer estudar, e as conclusões são estendidas ao universo, analisando-se estatisticamente as margens de erro envolvidas.

As principais vantagens do Levantamento são:

- Conhecimento direto da realidade.

- Economia e rapidez.

- Quantificação.

As principais limitações são:

- Ênfase nos aspectos perceptivos, ou seja, ele recolhe a percepção que as pessoas tem de si mesmas, o que pode ser um dado subjetivo.

- Pouca profundidade no estudo das estruturas e dos processos sociais.

- Limitada apreensão dos processos de mudança.

\subsubsection{Estudo de Caso.}

É o estudo exaustivo e detalhado de um ou poucos objetos, de modo a obter um conhecimento amplo e detalhado. É muito utilizado em pesquisas exploratórias e recomendado nas fases iniciais de uma investigação sobre temas complexos. Este tipo de pesquisa estimula as novas descobertas e dá ênfase na totalidade das dimensões de um problema. 


\subsubsection{Pesquisa - Ação.}

De acordo com Thiollent, M. (1985), citado em Gil, A.C., a pesquisa ação é definida como “...um tipo de pesquisa com base empírica que é concebida e realizada em estreita associação com uma ação ou com a resolução de um problema coletivo e no qual os pesquisadores e participantes representativos da situação ou do problema estão envolvidos de modo cooperativo ou participativo". É um tipo de pesquisa que envolve a participação direta do pesquisador, atuando em conjunto com as pessoas ou grupos envolvidos no problema objeto da pesquisa.

\subsubsection{Pesquisa Participante.}

Também é caracterizada pela interação entre pesquisadores e membros das situações investigadas, de modo semelhante à pesquisa - ação. A diferença esta no fato da pesquisa participante distinguir ciência popular e ciência dominante, sendo esta última caracterizada pela manutenção do sistema vigente; ao passo que a pesquisa - ação supõe uma forma de ação planejada, de caráter social, educacional, técnico, etc., ou seja, ela interage e influencia o meio de estudo.

Muitos autores consideram as pesquisas ação e participante como sinônimos.

\subsection{Métodos de Coleta de Dados.}

De acordo com Bryman, A. (1989) os principais métodos de coletas de dados são:

\subsubsection{Questionário Administrativo.}

É um questionário estruturado, encaminhado aos integrantes da amostra de estudo para uma resposta isolada, sem a interação do pesquisador. Todos os questionários envolvidos são idênticos, de forma a eliminar variações de respostas.

\subsubsection{Entrevista Estruturada.}

É a aplicação de um questionário estruturado, como no caso anterior, porém com a participação direta do pesquisador, que atua juntamente com os integrantes da amostra em análise. 


\subsubsection{Observação Participante.}

É uma observação pessoal e direta por parte do pesquisador, que permanece um longo tempo dentro de uma organização em análise, a fim de fazer as observações do estudo em primeira mão.

\subsubsection{Entrevista Não - Estruturada.}

A entrevista é feita de modo não estruturada, através de questionário sem programação pré-existente, permitindo-se maior liberdade de respostas por parte dos integrantes da amostra em análise. O objetivo é captar o pensamento do respondente, com o pesquisador cuidando para não fugir do tema central.

\subsubsection{Observação Estruturada.}

É a observação direta do pesquisador sobre o dia-a-dia de uma organização, de forma detalhada e com as observações seguindo uma programação previamente formulada. Neste caso, o pesquisador participa ativamente e de forma detalhada com a organização.

\subsubsection{Simulacão.}

É a tentativa de se estabelecer um grande conjunto de realidades associadas a um fato, através da análise das variáveis envolvidas no fenômeno em estudo. São criados diferentes "cenários" representando variantes da realidade, resultantes das alterações programadas e estruturadas das variáveis.

\subsubsection{Informação de Arquivo.}

O pesquisador utiliza arquivos para conduzir sua realidade, como uma forma indireta de coleta de dados. A credibilidade dependerá da veracidade dos arquivos analisados. 


\subsection{A Escolha do Projeto de Pesquisa.}

O objetivo desta pesquisa é identificar a visão que o pequeno e médio empresário tem a respeito de inovação, e do mesmo modo, identificar as atividades voltadas à inovação eventualmente mais utilizadas nas práticas gerenciais das empresas de pequeno e médio porte do Estado de São Paulo.

Conforme vimos no capítulo anterior e no início deste capítulo, as grandes empresas possuem cultura e canais voltados ao processo de inovação, sendo por este motivo, não incluídas nesta pesquisa. Além disso, a inclusão destas empresas poderia tornar o trabalho mais lento, oneroso e menos flexível, devido às dificuldades de acesso aos profissionais ligados ao processo de inovação.

Fundamentalmente, procuraremos nos concentrar nas pequenas e médias empresas, visto serem mais suscetíveis à rápida inovação tecnológica e menos estruturadas ao contato com os canais geradores da inovação. Procuraremos estabelecer as maiores carências e pontos fracos frente a este processo de inovação, concentrando-nos nos seguintes aspectos:

- Existência e forma da administração da área de P\&D;

- Existência ou não da cultura da inovação;

- Fontes de inovação às quais a empresa recorre;

- Metodologia de absorção da inovação;

- Políticas de treinamento do Capital Intelectual;

- Aplicação de ferramentas da Qualidade. 


\subsubsection{A Definição do Projeto Escolhido}

Considerando-se a amostra a ser trabalhada, aliada ao fato que procuraremos avaliar uma situação localizada no modo administrativo das empresas, sem ênfase no ponto de vista do entrevistado, definimos a seguinte estrutura de pesquisa:

- Modelo de Pesquisa Descritiva.

- Abordagem Qualitativa.

- Classificação de Pesquisa do tipo Survey (Levantamento).

- Coleta de dados através de Questionário Administrativo.

\subsubsection{Operacionalizacão das variáveis}

Os dados obtidos serão agrupados em gráficos de Pareto, para posterior análise estatística. Será pesquisada a aplicação de algum software estatístico adequado à coleta dos dados.

\section{$\underline{\text { 3.6.3 Amostragem }}$}

A amostragem a ser utilizada neste levantamento foi obtida junto a:

- SEBRAE-SP, agência Diadema (com a colaboração do Eng. José Lourenço Melro);

\subsubsection{Técnicas de coleta de dados;}

De acordo com Selltiz, C. et alii (1985), citado em Terra, J.C. Cyrineu, Gestão do Conhecimento, Tese de Doutorado, 1999, o método da entrevista é melhor que a aplicação do questionário. Entretanto, optamos pela aplicação de questionários via internet devido à rapidez dos resultados, menor volume de recursos financeiros necessários e possibilidade de maior amostragem utilizada.

O questionário aplicado está reproduzido no Anexo 1.

\subsection{Pré-teste do instrumento}

Serão selecionadas algumas empresas para aplicação direta do questionário a fim de avaliar-se a necessidade de alguma alteração e/ou correção. 


\section{Capítulo 4 - Gestão da Inovação.}

Gestão da Inovação Tecnológica na Pequena e Média Empresa no Estado de São Paulo - Setores da Eletroeletrônica e Telecomunicações.

\subsection{Metodologia.}

O capítulo 4 está baseado nos dados coletados no campo, entre julho de 2000 e maio de 2001, através de levantamento (Survey) executado através de questionário aplicado via internet.

O objetivo deste levantamento foi avaliar o grau de conhecimento do processo de inovação por parte das empresas participantes e o modo como estas empresas aplicam o processo de inovação em seus produtos.

A proposta é verificar o engajamento do segmento da pequena e média empresa no processo de inovação.

\subsubsection{Conceitos básicos.}

Os principais focos desta pesquisa são:

- A visualização do processo de inovação como aspecto estratégico para a empresa,

- A aplicação sistemática do processo de inovação ao longo da vida do produto e de seu processo de fabricação,

- O rastreamento do ambiente externo e interno, na busca de oportunidades de inovação,

- O grau de importância dado ao Capital Intelectual,

- O grau de conhecimento das principais fontes de inovação, por parte das empresas,

- O grau de engajamento na dinâmica da inovação. 


\subsubsection{Amostra}

A amostra baseou-se no cadastro das pequenas e médias empresas do SEBRAE, concentradas nos segmentos da eletroeletrônica e telecomunicações. Foram pesquisadas duas empresas produtoras de software, mas seus dados não serão incluídos nos dados da pesquisa, sendo utilizados apenas como comparação junto aos resultados das demais 21 empresas do segmento eletroeletrônico e de telecomunicações

As empresas foram previamente contatadas, para esclarecimento da finalidade e objetivo da pesquisa. Foram encaminhados 247 questionários de pesquisa, com a concordância e pré-conhecimento por parte dos pesquisados. O retorno de 23 questionários correspondeu a 9,3\% do total de questionários encaminhados.

\subsubsection{O instrumento de coleta de dados.}

O questionário de pesquisa foi dividido em 4 partes:

- Parte 1: Dados da empresa, verificando o perfil do respondente, porte da empresa, formação do capital, especialidade tecnológica, participação de mercado e inserção no segmento exportador.

- Parte 2: Aspectos administrativos, verificando-se o perfil inovador da empresa, sua busca de novas tecnologias e seu processo de geração de novos produtos.

- Parte 3: Relacionamento com o ambiente externo, verificando-se o grau de interação da empresa com seus clientes, fornecedores e parceiros de mercado.

- Parte 4: Mecanismos de Implementação, verificando-se o grau de engajamento no processo de busca e implementação da inovação.

- Parte 5: Contexto interno, verificando-se o modo de estrutura organizacional, abertura à criatividade e processamento interno da informação. 


\subsection{Dados coletados.}

A seguir temos o detalhamento dos dados coletados, para cada pergunta e para cada parte do questionário. O detalhamento dos itens foi elaborado na forma de tabelas com dados condensados, os quais serão utilizados para a análise estatística do item 4.2.6 Discussão Geral sobre o Levantamento.

\subsubsection{Parte 1 - Dados da empresa}

\subsubsection{Perfil profissional de quem respondeu ao questionário.}

Perguntas 1 e 2: Área onde trabalha e Cargo do Respondente.

Os questionários estruturados foram encaminhados aos responsáveis diretos das empresas, pois é a pessoa que contém as informações referentes a faturamento bruto, percentual de investimentos, avaliação global da mão de obra, entre outros dados, importantes para este levantamento. O perfil do profissional abordado está indicado na tabela abaixo.

Tabela 5: Área de atuação e cargo de quem respondeu ao questionário

\begin{tabular}{|c|c|c|}
\hline Área de Atuação & Quant. & $\%$ \\
\hline Diretoria Geral & 13 & 59,1 \\
\hline Marketing / Vendas & 3 & 13,6 \\
\hline Financeiro & 2 & 9,1 \\
\hline Qualidade & 2 & 9,1 \\
\hline Desenvolvimento & 1 & 4,5 \\
\hline Recursos Humanos & 1 & 4,5 \\
\hline
\end{tabular}

\begin{tabular}{|c|c|c|}
\hline Cargo & Quant. & $\%$ \\
\hline Presidente & 10 & 47,6 \\
\hline Gerente & 7 & 33,3 \\
\hline Diretor & 3 & 14,3 \\
\hline Supervisor & 1 & 4,8 \\
\hline
\end{tabular}

Obs.: No quadro referente à área de atuação, ocorrem 22 áreas porque um dos respondentes é responsável por Qualidade e Desenvolvimento.

\subsubsection{Perfil da empresa.}

Perguntas 3 a 6: Referentes ao nome, à razão social, endereço, CEP e Cidade.

As empresas pequenas e médias empresas consultadas são integrantes do cadastro SEBRAE, para o setor eletroeletrônico. 
Pergunta 7: Número de funcionários da empresa.

Pergunta 8: Quantidade de engenheiros trabalhando na empresa.

Em termos de número de funcionários, o menor observado foi em uma empresa com 8 colaboradores enquanto o maior número observado foi de 420 colaboradores, conforme a tabela a seguir.

Tabela 6: Número de funcionários e engenheiros por empresa pesquisada

\begin{tabular}{||c|c|}
\hline $\begin{array}{c}\text { Número de } \\
\text { funcionários }\end{array}$ & $\begin{array}{c}\text { Quantidade de } \\
\text { empresas (\%) }\end{array}$ \\
\hline De 5 a 10 & $2(9,5)$ \\
\hline De 11 a 20 & $1(4,8)$ \\
\hline De 21 a 40 & $5(23,8)$ \\
\hline De 41 a 60 & $1(4,8)$ \\
\hline De 61 a 80 & $1(4,8)$ \\
\hline De 81 a 100 & $2(9,5)$ \\
\hline De 101 a 300 & $6(28,6)$ \\
\hline De 301 a 450 & $3(14,3)$ \\
\hline
\end{tabular}

\begin{tabular}{||c|c||}
\hline $\begin{array}{c}\text { Número de } \\
\text { engenheiros }\end{array}$ & $\begin{array}{c}\text { Quantidade de } \\
\text { empresas (\%) }\end{array}$ \\
\hline 1 a 3 & $10(47,6)$ \\
\hline 4 a 6 & $5(23,8)$ \\
\hline 7 a 9 & $2(9,5)$ \\
\hline 10 ou mais & $4(19,0)$ \\
\hline Nenhum & 0 \\
\hline
\end{tabular}

Quanto ao número de engenheiros trabalhando na empresa, há variação bastante acentuada, quando se observa a composição do capital da empresa, conforme veremos posteriormente, na conclusão.

Pergunta 9: Principal produto e/ou especialidade da empresa (perfil tecnológico).

Pergunta 10: Formação do capital da empresa.

Pergunta 11: A posição de mercado da empresa, em sua especialidade.

O perfil tecnológico da empresa (conforme tabela 7) indica um total de dezenove categorias profissionais porque várias empresas trabalham com mais de um produto ou segmento. É o caso de empresas fabricantes de módulos eletrônicos destinados aos segmentos de eletrodomésticos nas linhas branca (cozinha e lavanderia) e marrom (som e entretenimento) e segmento automotivo. Os produtos, porém, apresentam perfil tecnológico semelhante.

Em termos de formação do capital, buscou-se incluir na amostra empresas com capital nacional, capital misto e estrangeiro, a fim de confrontarmos a visão do empresário nacional com a visão do investidor estrangeiro. Os dados referentes à posição de mercado encontram-se a seguir (tabela 8). 
Tabela 7: Perfil tecnológico da empresa.

\begin{tabular}{|c|c|c|}
\hline Principal produto/especialidade da empresa & Qtd & $\%$ \\
\hline Componentes Elétricos. & 9 & 19,6 \\
\hline Aparelhos elétricos para usos doméstico e pessoal. & 4 & 8,7 \\
\hline Material elétrico para veículos, peças e acessórios. & 4 & 8,7 \\
\hline Máquinas, aparelhos e equipamentos para medição. & 3 & 6,5 \\
\hline Material eletro eletrônico e de comunicação. & 3 & 6,5 \\
\hline Peças e acessórios para máquinas e aparelhos elétricos. & 3 & 6,5 \\
\hline Aparelhos e utensílios para fins industriais, comerciais e rurais *. & 2 & 4,3 \\
\hline Componentes elétricos estampados. & 2 & 4,3 \\
\hline Máquinas e equipamentos para geração, transmissão, distribuição, medição e controle. & 2 & 4,3 \\
\hline Máquinas e aparelhos para indústria de produtos alimentares. & 2 & 4,3 \\
\hline Máquinas e aparelhos para refrigeração e ventilação. & 2 & 4,3 \\
\hline Peças e acessórios para aparelhos e equiptos de comunicação, imagem, som e entretenimento. & 2 & 4,3 \\
\hline Peças e acessórios para máquinas, aparelhos e equipamentos de informática. & 2 & 4,3 \\
\hline Condutores elétricos. & 1 & 2,2 \\
\hline Máquinas, aparelhos e equipamentos de sistemas eletrônicos para processamento de dados. & 1 & 2,2 \\
\hline Máquinas, aparelhos e equipamentos de sistemas eletrônicos para automação gerencial. & 1 & 2,2 \\
\hline Máquinas, aparelhos e equipamentos para indústria química. & 1 & 2,2 \\
\hline Material eletrônico básico. & 1 & 2,2 \\
\hline Material para instalações elétricas. & 1 & 2,2 \\
\hline Total de especialidades de empresas & 46 & 100 \\
\hline
\end{tabular}

* Neste caso estão incluídas duas empresas fabricantes de multímetros, registradores gráficos e controladores de painéis de máquinas industriais. A descrição acima, utilizada pelo SEBRAE e FIESP, engloba também produtos destinados ao segmento agrícola, não sendo porém, a área de atuação das empresas pesquisadas.

Tabela 8: Composição do capital da empresa e posição de mercado.

\begin{tabular}{|c|c|}
\hline Capital & $\begin{array}{c}\text { Quantidade } \\
\text { de empresas } \\
(\%)\end{array}$ \\
\hline 100\% nacional & $14(66,7)$ \\
\hline 100\% estrangeiro & $4(19,9)$ \\
\hline Misto (nacional + estrangeiro) & $3(14,3)$ \\
\hline Participação governamental & 0 \\
\hline
\end{tabular}

\begin{tabular}{|c|c|}
\hline $\begin{array}{c}\text { Posição de } \\
\text { mercado }\end{array}$ & $\begin{array}{c}\text { Quantidade } \\
\text { de empresas } \\
(\%)\end{array}$ \\
\hline Líder & $9(42,9)$ \\
\hline Segunda posição & ------ \\
\hline Terceira posição & $2(9,5)$ \\
\hline Não sei & $7(33,3)$ \\
\hline Outras & $3(14,3)$ \\
\hline
\end{tabular}

Pergunta 12: Faturamento anual bruto, em dólar.

Com relação ao faturamento bruto anual, temos a tabela a seguir: 
Tabela 9:Faturamento anual bruto em US\$ (1 US\$ $\approx 2 R \$)$

\begin{tabular}{||c|c|c||}
\hline Faturamento bruto anual & Qtd & $\%$ \\
\hline Menos de $10.000,00$ & 0 & 0 \\
\hline de $10.001,00$ a $20.000,00$ & 0 & 0 \\
\hline de $20.001,00$ a $30.000,00$ & 0 & 0 \\
\hline de 30.001,00 a $40.000,00$ & 0 & 0 \\
\hline de 40.001,00 a $50.000,00$ & 0 & 0 \\
\hline de 50.001,00 a $60.000,00$ & 0 & 0 \\
\hline de 60.001,00 a 70.000,00 & 0 & 0 \\
\hline de 70.001,00 a $80.000,00$ & 0 & 0 \\
\hline de $80.001,00$ a $90.000,00$ & 0 & 0 \\
\hline de 90.001,00 a $100.000,00$ & 0 & 0 \\
\hline de 100.001,00 a $150.000,00$ & 0 & 0 \\
\hline de 150.001,00 a 200.000,00 & 0 & 0 \\
\hline de 200.001,00 a 300.000,00 & 3 & 14,3 \\
\hline de 300.001,00 a 500.000,00 & 5 & 23,8 \\
\hline de 500.001,00 a 1 milhão & 2 & 9,5 \\
\hline Mais de 1 milhão & 11 & 52,4 \\
\hline
\end{tabular}

Pergunta 13: Sua participação de mercado, em sua especialidade é de:

Pergunta 14: (A evolução de mercado) Nos últimos 2 anos, a empresa:

Abaixo, temos dados referentes à participação de mercado e à evolução da participação de mercado da empresa nos últimos anos.

Tabela 10: Participação e evolução de mercado nos últimos dois anos.

\begin{tabular}{||l|c|}
\hline Fatia de mercado & $\begin{array}{c}\text { Quant. de } \\
\text { empresas } \\
(\%)\end{array}$ \\
\hline Menos de 10\% & $7(33,3)$ \\
\hline De 10 a 20\% & $5(23,8)$ \\
\hline De 20 a 30\% & $2(9,5)$ \\
\hline De 30 a 50\% & $3(14,3)$ \\
\hline Mais de 50\% & $4(19,0)$ \\
\hline Não sei & 0 \\
\hline
\end{tabular}

\begin{tabular}{||l|c||}
\hline \multicolumn{1}{|c|}{ Evolução nos últimos 2 anos } & $\begin{array}{l}\text { Quant. de } \\
\text { empresas } \\
(\%)\end{array}$ \\
\hline Ganhou mercado acentuadamente & $5(23,8)$ \\
\hline Ganhou mercado levemente & $6(28,6)$ \\
\hline Manteve mercado & $3(14,3)$ \\
\hline Perdeu mercado levemente & $6(28,6)$ \\
\hline Perdeu mercado acentuadamente & $1 \quad(4,8)$ \\
\hline
\end{tabular}

Pergunta 15: As exportações correspondem a:

Pergunta 16: O impacto da abertura de mercado brasileiro, para sua empresa, foi:

A seguir estão agrupados os dados referentes a percentual do faturamento correspondente à exportação e o impacto da abertura do mercado sobre a empresa. 
Tabela 11: Exportação sobre faturamento e impacto da abertura de mercado

\begin{tabular}{|l|c|}
\hline \multicolumn{1}{|c|}{$\begin{array}{c}\text { Exportação sobre } \\
\text { Faturamento }\end{array}$} & $\begin{array}{c}\text { Quant. } \\
(\%)\end{array}$ \\
\hline Até $10 \%$ do faturamento & $12(57,1)$ \\
\hline 11 a $20 \%$ do faturamento & $4(19,0)$ \\
\hline 21 a 30\% do faturamento & 0 \\
\hline 31 a 50\% do faturamento & 0 \\
\hline Mais de 50\% do faturamento & 0 \\
\hline Não exporta & $5(23,8)$ \\
\hline
\end{tabular}

\begin{tabular}{|l|c|}
\hline Impacto da abertura & $\begin{array}{c}\text { Quant. } \\
(\%)\end{array}$ \\
\hline Excelente & 0 \\
\hline Muito bom & $3(14,3)$ \\
\hline Bom & $4(19,0)$ \\
\hline Indiferente & $2(9,5)$ \\
\hline Negativo & $10(47,6)$ \\
\hline Muito negativo & $2(9,5)$ \\
\hline
\end{tabular}

\subsubsection{Parte 2 - Aspectos Administrativos}

Neste item, fizemos a analise da amostra de empresas frente ao ambiente da inovação tecnológica. Um dado importante é a quase unanimidade das respostas, atribuindo as maiores oportunidades de inovação concentradas na tecnologia e na mão de obra (capital intelectual) da empresa, conforme a tabela a seguir.

Pergunta 17: Onde você acredita que se encontra a maior oportunidade de inovação que sua empresa pode utilizar? Cite no máximo duas oportunidades.

Tabela 12: Onde se encontra a maior oportunidade de inovação para a empresa

\begin{tabular}{||l|c|}
\hline \multicolumn{1}{|c|}{$1^{\text {a }}$ Opção } & Qtd \\
\hline Na tecnologia disponível & 16 \\
\hline Na qualificação dos funcionários & 2 \\
\hline Nos seus clientes & 1 \\
\hline No preço dos seus insumos & 1 \\
\hline Na imagem da empresa & 1 \\
\hline Nos seus fornecedores & 0 \\
\hline Na demanda do mercado & 0 \\
\hline Na concorrência & 0 \\
\hline
\end{tabular}

\begin{tabular}{||l|c|}
\hline \multicolumn{1}{|c|}{$2^{\text {a }}$ Opção } & Qtd \\
\hline Na qualificação dos funcionários & 15 \\
\hline Na demanda do mercado & 2 \\
\hline No preço dos seus insumos & 2 \\
\hline Na tecnologia disponível & 2 \\
\hline Nos seus fornecedores & 0 \\
\hline Nos seus clientes & 0 \\
\hline Na concorrência & 0 \\
\hline Outros (especifique, se quiser): & 0 \\
\hline
\end{tabular}

Esta pergunta admitia até duas respostas, classificadas por 1 e 2 , conforme a importância atribuída. À esquerda estão as respostas classificadas como mais importantes. À direita está a segunda resposta por ordem de importância. 
Pergunta 18: Na sua opinião, quais os aspectos mais importantes a serem analisados quando se comparam produtos entre concorrentes? Cite no máximo três aspectos.

De acordo com a tabela a seguir, observamos que a tecnologia envolvida é o dado mais importante para a avaliação dos produtos, ou seja, a tecnologia é reconhecida como aspecto estratégico.

Tabela 13: Aspectos importantes no estudo comparativo com produto concorrente

\begin{tabular}{|l|c|}
\hline \multicolumn{1}{|c|}{$1^{\text {a } \text { Opção }}$} & $\begin{array}{c}\text { Qtd } \\
(\%)\end{array}$ \\
\hline O próprio produto & $\begin{array}{c}9 \\
(42,9)\end{array}$ \\
\hline A qualidade & $\begin{array}{c}5 \\
(23,8)\end{array}$ \\
\hline O preço & $\begin{array}{c}3 \\
(14,3)\end{array}$ \\
\hline Tecnologia envolvida & $\begin{array}{c}3 \\
(14,3)\end{array}$ \\
\hline Os serviços & $\begin{array}{c}1 \\
(4,8)\end{array}$ \\
\hline Prazos de entrega & 0 \\
\hline Logística/desempenho & 0 \\
\hline \hline
\end{tabular}

\begin{tabular}{||l|c||}
\hline \multicolumn{1}{|c|}{$2^{\text {a Opção }}$} & $\begin{array}{c}\text { Qtd } \\
(\%)\end{array}$ \\
\hline O preço & $\begin{array}{c}7 \\
(38,9)\end{array}$ \\
\hline A qualidade & $\begin{array}{c}5 \\
(27,8)\end{array}$ \\
\hline Tecnologia envolvida & $\begin{array}{c}4 \\
(22,2)\end{array}$ \\
\hline O próprio produto & $\begin{array}{c}1 \\
(5,6)\end{array}$ \\
\hline Logística/desempenho & $\begin{array}{c}1 \\
(5,6)\end{array}$ \\
\hline Prazos de entrega & $\begin{array}{c}1 \\
(5,6)\end{array}$ \\
\hline Os serviços & 0 \\
\hline
\end{tabular}

\begin{tabular}{||l|c|}
\hline \multicolumn{1}{|c|}{$3^{\text {a } \text { Opção }}$} & $\begin{array}{c}\text { Qtd } \\
(\%)\end{array}$ \\
\hline O preço & $\begin{array}{c}5 \\
(33,3)\end{array}$ \\
\hline Tecnologia envolvida & $\begin{array}{c}5 \\
(33,3)\end{array}$ \\
\hline Logística/desempenho & $\begin{array}{c}3 \\
(20,0)\end{array}$ \\
\hline Os serviços & $\begin{array}{c}1 \\
(6,7)\end{array}$ \\
\hline Prazos de entrega & $\begin{array}{c}1 \\
(6,7)\end{array}$ \\
\hline A qualidade & 0 \\
\hline O próprio produto & 0 \\
\hline
\end{tabular}

Pergunta 19: Que fonte de informação você mais utiliza para comparar-se aos concorrentes? Cite no máximo duas fontes.

Tabela 14: Fontes de informação mais usadas na análise comparativa com produtos concorrentes

\begin{tabular}{||c|c|c|}
\hline $1^{\text {a }}$ Opção & Qtd & $\%$ \\
\hline O produto do concorrente & 18 & 85,7 \\
\hline Benchmarking & 2 & 9,5 \\
\hline Pesquisa de mercado & 1 & 4,8 \\
\hline Publicações especializadas & & \\
\hline Análise de patentes & & \\
\hline Outras (cite, se quiser) & & \\
\hline Nada / Nenhuma fonte & & \\
\hline
\end{tabular}

\begin{tabular}{||c|c|c|}
\hline $2^{\text {a }}$ Opção & Qtd & $\%$ \\
\hline Benchmarking & 11 & 55,0 \\
\hline Pesquisa de mercado & 4 & 20,0 \\
\hline O produto do concorrente & 2 & 10,0 \\
\hline Publicações especializadas & 2 & 10,0 \\
\hline Outras: Feiras & 1 & 5,0 \\
\hline Análise de patentes & & \\
\hline Nada / Nenhuma fonte & & \\
\hline
\end{tabular}

Pergunta 20: Em sua opinião, qual o modo mais adequado para se obter novas tecnologias? Cite no máximo três fontes de tecnologia.

A maioria das respostas indica a pesquisa e desenvolvimento próprio como estratégia para a empresa. Entretanto, a indicação de "feiras e eventos" como fontes de inovação 
indicam baixa consistência de critério tecnológico, pois uma "feira técnica" apresenta produtos já desenvolvidos e não dá qualquer indício referente aos processos, igualmente fundamentais no que se refere à inovação tecnológica.

Tabela 15: Indicação das fontes de inovação mais adequadas.

\begin{tabular}{|c|c|}
\hline $1^{\text {a }}$ Opção & Qtd \\
\hline $\begin{array}{c}\text { Pesquisa e desenvolvimento } \\
\text { próprios }\end{array}$ & 15 \\
\hline Joint ventures (uniões) & 2 \\
\hline Através dos fornecedores & 1 \\
\hline Através dos clientes & 1 \\
\hline Engenharia reversa & 1 \\
\hline $\begin{array}{c}\text { Pagando royalts } \\
\text { (licenciamento) }\end{array}$ & 1 \\
\hline Leasing & \\
\hline Feiras ou eventos similares & \\
\hline "Chupando" & \\
\hline Universidades & \\
\hline Pesquisa contratada & \\
\hline Outras (cite, se quiser) & \\
\hline \hline
\end{tabular}

\begin{tabular}{|c|c|}
\hline $2^{\text {a }}$ Opção & Qtd \\
\hline Joint ventures (uniões) & 7 \\
\hline Feiras ou eventos similares & 4 \\
\hline $\begin{array}{c}\text { Pesquisa e desenvolvimento } \\
\text { próprios }\end{array}$ & 2 \\
\hline Através dos fornecedores & 2 \\
\hline Através dos clientes & 2 \\
\hline Engenharia reversa & 2 \\
\hline "Chupando" & 1 \\
\hline Universidades & 1 \\
\hline Leasing & \\
\hline $\begin{array}{c}\text { Pagando royalts } \\
\text { (licenciamento) }\end{array}$ & \\
\hline Pesquisa contratada & \\
\hline Outras (cite, se quiser) & \\
\hline \hline
\end{tabular}

\begin{tabular}{|c|c||}
\hline $3^{\text {a }}$ Opção & Qtd \\
\hline Feiras ou eventos similares & 12 \\
\hline Através dos fornecedores & 3 \\
\hline Através dos clientes & 2 \\
\hline Pesquisa contratada & 1 \\
\hline Engenharia reversa & 1 \\
\hline $\begin{array}{c}\text { Pagando royalts } \\
\text { (licenciamento) }\end{array}$ & 1 \\
\hline Joint ventures (uniões) & 1 \\
\hline $\begin{array}{c}\text { Pesquisa e desenvolvimento } \\
\text { próprios }\end{array}$ & \\
\hline $\begin{array}{c}\text { "Chupando" } \\
\text { Leasing }\end{array}$ \\
\hline Universidades & \\
\hline Outras (cite, se quiser) & \\
\hline
\end{tabular}

Do mesmo modo, fornecedores e clientes aparecem como importantes indicadores de tendência tecnológica, apesar de uma indicação isolada da universidade como indicadora de tendência tecnológica, conforme a tabela baixo.

Pergunta 21: O que você acha melhor para manter a vantagem competitiva sobre os concorrentes? Cite no máximo duas respostas.

De acordo com Terra, J.C.C. (item 2.1.5 - A vantagem competitiva gerada pela inovação) o crescimento de mercado está fortemente associado à inovação tecnológica (vide figura 2). Entretanto, esta pergunta indicou "custos e rapidez de acesso ao mercado" à frente de pesquisa ou o desenvolvimento técnico, conforme a tabela abaixo.

Tabela 16: Manutenção da vantagem competitiva.

\begin{tabular}{||l|c|c||}
\hline \multicolumn{1}{|c|}{$1^{\text {a }}$ Opção } & Qtd & $\%$ \\
\hline Acúmulo de conhecimento & 12 & 57,1 \\
\hline Rapidez para chegar ao mercado & 5 & 23,8 \\
\hline Redução sistemática de custos & 3 & 14,3 \\
\hline Segredo profissional & 1 & 4,8 \\
\hline Pesquisa interna & & \\
\hline Ter patentes & & \\
\hline Ter um produto complexo & & \\
\hline Outras (cite, se quiser) & & \\
\hline
\end{tabular}

\begin{tabular}{||l|c|c||}
\hline \multicolumn{1}{|c|}{$2^{\text {a }}$ Opção } & Qtd & $\%$ \\
\hline Redução sistemática de custos & 14 & 77,8 \\
\hline Rapidez para chegar ao mercado & 2 & 11,1 \\
\hline Acúmulo de conhecimento & 1 & 5,6 \\
\hline Pesquisa interna & 1 & 5,6 \\
\hline Ter um produto complexo & 1 & 5,6 \\
\hline Ter patentes & & \\
\hline Segredo profissional & & \\
\hline Outras (cite, se quiser) & & \\
\hline
\end{tabular}


Como terceira opção houve apenas duas respostas, referentes a segredo profissional e produto complexo.

Pergunta 22: Que categoria você classificaria como mais próxima da especialidade de sua empresa?

Um aspecto importante refere-se à categoria empresarial das empresas participantes. Os dados sintetizados estão indicados abaixo.

\section{Tabela 17: Classificação da categoria empresarial}

\begin{tabular}{|l|c|c||}
\hline Categoria empresarial & Qtde & $\%$ \\
\hline Fornecedor sob encomenda / contratado & 9 & 42,9 \\
\hline Fornecedor tecnologicamente especializado (pouca concorrência) & 4 & 19,0 \\
\hline Produtor final em larga escala & 3 & 14,3 \\
\hline Produtor final tecnologicamente especializado (pouca concorrência & 3 & 14,3 \\
\hline Fornecedor majoritário & 2 & 9,5 \\
\hline Produtor final em pequena escala & & \\
\hline Fornecedor minoritário & & \\
\hline Outras (cite, se quiser) & & \\
\hline
\end{tabular}

Pergunta 23: Onde você acha que está situada sua maior competência empresarial?

Com relação à competência empresarial, a escolha novamente recai sobre a inovação tecnológica e o capital intelectual, conforme já observado na tabela 12 e indicado na tabela 16, a seguir. Nesta resposta, várias empresas apontaram espontaneamente mais de uma resposta. Todas foram registradas.

\section{Tabela 18: Localização da competência empresarial}

\begin{tabular}{|l|c|c|}
\hline \multicolumn{1}{|c|}{ Localização } & Qtd. & $\%$ \\
\hline Na tecnologia interna & 11 & 32,4 \\
\hline Competência de seu pessoal & 9 & 26,5 \\
\hline Na sua área de P\&D & 7 & 20,6 \\
\hline Na área de vendas & 3 & 8,8 \\
\hline Outras (cite, se quiser): Confiabilidade, Qualidade, Processo. & 2 & 5,9 \\
\hline Na área de compras & 1 & 2,9 \\
\hline Na logística de distribuição & 1 & 2,9 \\
\hline
\end{tabular}

Pergunta 24: Você identifica alguma ameaça à sua empresa, em função da evolução tecnológica?

Pergunta 25: Você vê alguma oportunidade para sua empresa, em função da evolução tecnológica? 
Pergunta 26: Sua empresa te estrutura formal fixa, voltada à inovação?

Pergunta 28: No momento está desenvolvendo alguma inovação tecnológica?

Pergunta 31: Seus processos de produção são documentados?

Pergunta 32: Seus processos de desenvolvimento de produto são documentados?

Pergunta 33: As análises de processo produtivo são documentadas?

Tabela 19: Processos de desenvolvimento, administração, produtivo e registros

\begin{tabular}{|l|c|c|c|c|c||}
\hline & sim & não & talvez & não sei & parcialmente \\
\hline $\begin{array}{l}\text { Você identifica alguma ameaça à sua empresa, em } \\
\text { função da evolução tecnológica? }\end{array}$ & $\begin{array}{c}16 \\
(76,2)\end{array}$ & $\begin{array}{c}3 \\
(14,3)\end{array}$ & $\begin{array}{c}2 \\
(9,5)\end{array}$ & 0 & \\
\hline $\begin{array}{l}\text { Você vê alguma oportunidade para sua empresa, em } \\
\text { função da evolução tecnológica? }\end{array}$ & $\begin{array}{c}19 \\
(90,5)\end{array}$ & $\begin{array}{c}2 \\
(9,5)\end{array}$ & 0 & 0 & \\
\hline $\begin{array}{l}\text { Sua empresa tem uma estrutura formal fixa (pessoas, } \\
\text { área, equipamentos, etc.) voltada à inovação? }\end{array}$ & $\begin{array}{c}15 \\
(71,4)\end{array}$ & $\begin{array}{c}5 \\
(23,8)\end{array}$ & & & 1 \\
\hline $\begin{array}{l}\text { No momento você está desenvolvendo alguma } \\
\text { inovação tecnológica, objetivando um novo produto? }\end{array}$ & $\begin{array}{c}17 \\
(81,0)\end{array}$ & $\begin{array}{c}4 \\
(19,0)\end{array}$ & & & \\
\hline $\begin{array}{l}\text { Seus processos de produção são documentados } \\
\text { (normas, procedimentos, folhas de processo, etc.)? }\end{array}$ & $\begin{array}{c}20 \\
(95,2)\end{array}$ & $\begin{array}{c}1 \\
(4,8)\end{array}$ & & & 0 \\
\hline $\begin{array}{l}\text { Seus processos de desenvolvimento de produto são } \\
\text { documentados (normas, procedimentos, etc.)? }\end{array}$ & $\begin{array}{c}19 \\
(90,5)\end{array}$ & $\begin{array}{c}1 \\
(4,8)\end{array}$ & & & 1 \\
\hline $\begin{array}{l}\text { As análises de processo produtivo são documentadas } \\
\text { (normas, procedimentos, folhas de processo, etc.)? }\end{array}$ & $\begin{array}{c}19 \\
(90,5)\end{array}$ & $\begin{array}{c}2 \\
(9,5)\end{array}$ & & \\
\hline
\end{tabular}

Com relação aos registros de processos de desenvolvimento, produtivo e administrativo, os resultados coletados foram plenamente satisfatórios. Há uma visão geral de que a documentação e o registro dos processos é fundamental.

Pergunta 27: Qual o percentual do faturamento despendido no desenvolvimento de alguma inovação ao longo deste ano?

Esta pergunta procurou comparar os dados das empresas amostradas com os dados indicados em 2.5.1.2 - Indicador Brasileiro de Inovação.

Tabela 20: Percentual do faturamento investido em inovação e P\&D

\begin{tabular}{|c|c|c|}
\hline Percentual do faturamento & Qtde & $\%$ \\
\hline Entre 1\% e 3\% & 13 & 61,9 \\
\hline Até 1\% & 5 & 23,8 \\
\hline Acima de 3\% & 3 & 4,8 \\
\hline 0 & 0 & 0 \\
\hline
\end{tabular}

Pergunta 29: Na sua opinião, qual o melhor veículo para indicação de novas tendências tecnológicas, ainda na fase inicial? Cite até três. 
De acordo com Tidd, J. e Trewella, M., as fontes de inovação menos críticas e mais importantes são a universidade e as alianças empresariais (vide figura 10), fontes pouco apontadas nesta avaliação.

Tabela 21: Veículos indicadores de tendências tecnológicas.

\begin{tabular}{||l|c||}
\hline \multicolumn{1}{|c|}{$1^{\text {a }}$ Opção } & Q (\%) \\
\hline Pesquisa de Mercado & $\begin{array}{c}11 \\
(52,4)\end{array}$ \\
\hline Pesquisa informal & $\begin{array}{c}3 \\
(14,3)\end{array}$ \\
\hline P\&D internos & $\begin{array}{c}2 \\
(9,5)\end{array}$ \\
\hline Literatura especializada & $\begin{array}{c}2 \\
(9,5)\end{array}$ \\
\hline Feiras e eventos & $\begin{array}{c}1 \\
(4,8)\end{array}$ \\
\hline Através dos fornecedores & $\begin{array}{c}1 \\
(4,8)\end{array}$ \\
\hline Universidade & $\begin{array}{c}1 \\
(4,8)\end{array}$ \\
\hline Periódicos e publicações & \\
\hline Através dos concorrentes & \\
\hline Associações de classe & \\
\hline Através dos clientes & \\
\hline
\end{tabular}

\begin{tabular}{||l|c||}
\hline \multicolumn{1}{|c|}{$2^{\text {a }}$ Opção } & Q \\
\hline Feiras e eventos & $\begin{array}{c}11 \\
(52,4)\end{array}$ \\
\hline Através dos clientes & $\begin{array}{c}4 \\
(19,0)\end{array}$ \\
\hline Pesquisa de Mercado & $\begin{array}{c}2 \\
(9,5)\end{array}$ \\
\hline P\&D internos & $\begin{array}{c}1 \\
(4,8)\end{array}$ \\
\hline Literatura especializada & $\begin{array}{c}1 \\
(4,8)\end{array}$ \\
\hline Através dos fornecedores & $\begin{array}{c}1 \\
(4,8)\end{array}$ \\
\hline Periódicos e publicações & 1 \\
& \\
\hline Universidade & \\
\hline Através dos concorrentes & \\
\hline Associações de classe & \\
\hline Pesquisa informal & \\
\hline
\end{tabular}

\begin{tabular}{|c|c|}
\hline $3^{\mathrm{a}}$ Opção & $\overline{Q Q}$ \\
\hline Feiras e eventos & $\begin{array}{c}4 \\
(28,6)\end{array}$ \\
\hline Através dos clientes & $\begin{array}{c}3 \\
(21,4)\end{array}$ \\
\hline Através dos concorrentes & $\begin{array}{c}2 \\
(14,3)\end{array}$ \\
\hline Literatura especializada & $\begin{array}{c}2 \\
(14,3)\end{array}$ \\
\hline Pesquisa de Mercado & $\begin{array}{c}1 \\
(7,1)\end{array}$ \\
\hline P\&D internos & $\begin{array}{c}1 \\
(7,1)\end{array}$ \\
\hline Periódicos e publicações & $\begin{array}{c}1 \\
(7,1)\end{array}$ \\
\hline Universidade & \\
\hline Através dos fornecedores & \\
\hline Associações de classe & \\
\hline Pesquisa informal & \\
\hline
\end{tabular}

Pergunta 30: Indique as ferramentas estatísticas que você utiliza em seus processos de produção e desenvolvimento.

Tabela 22: Uso de ferramentas estatísticas de controle de processo.

\begin{tabular}{||l|c|c||}
\hline \multicolumn{1}{|c|}{ Ferramenta estatística } & Quantidade & $\%$ \\
\hline Coleta de dados de processo & 12 & 21,8 \\
\hline Histogramas & 11 & 20,0 \\
\hline Cartas de CEP & 8 & 14,5 \\
\hline Análise de Pareto & 8 & 14,5 \\
\hline Diagrama Ishikawa & 6 & 10,9 \\
\hline Nenhuma & 4 & 7,3 \\
\hline Diagrama de Correlação & 3 & 5,5 \\
\hline Delineamento de experimentos & 3 & 5,5 \\
\hline Outras (indicar) & 0 & 0 \\
\hline
\end{tabular}

\subsubsection{Parte 3 - Aspectos relacionados ao ambiente externo}

Com relação ao ambiente externo, podemos constatar uma forte interação com os clientes, principalmente em função da categoria empresarial das empresas pesquisadas 
(vide tabela 18). Mas mesmo assim, encontramos uma quantidade significativa (40\%) de empresas que não tem procedimentos escritos para desenvolver fornecedores, conforme vemos a seguir.

Pergunta 34: Você utiliza algum método para avaliar as necessidades e expectativas de seu cliente?

Tabela 23: Métodos de avaliação das expectativas e necessidades do cliente.

\begin{tabular}{|l|c|c|}
\hline Método de avaliação & Qtde & $\%$ \\
\hline Pesquisa de mercado & 13 & 32,5 \\
\hline Internet & 11 & 27,5 \\
\hline Outros (*) & 5 & 12,5 \\
\hline Linha telefônica 0800 & 5 & 12,5 \\
\hline QFD & 4 & 10,0 \\
\hline Método Delphi & 1 & 2,5 \\
\hline Nenhum & 1 & 2,5 \\
\hline
\end{tabular}

(*) Pesquisa e avaliação de dados do cliente.

Pergunta 35: Você conhece o perfil de seu cliente?

Pergunta 36: Você trabalha em parceria com seus fornecedores?

Pergunta 37: Sua empresa tem procedimentos escritos e documentados que estabelecem como desenvolver um fornecedor?

Pergunta 38: Você já fez acordo ou parceria cedendo parte de seus negócios em torça de tecnologia?

Tabela 24: Parceria e desenvolvimento de fornecedores.

\begin{tabular}{|l|c|c|c|}
\hline & sim & não & parcialmente \\
\hline Você conhece o perfil de seu cliente? & $19(90,5)$ & 0 & $2 \quad(9,5)$ \\
\hline Você trabalha em parceria com seus fornecedores? & $16(76,2)$ & $1(4,8)$ & $4(19,0)$ \\
\hline $\begin{array}{l}\text { Sua empresa tem procedimentos escritos e documentados } \\
\text { que estabelecem como desenvolver um fornecedor? }\end{array}$ & $15(71,4)$ & $6(28,6)$ & \\
\hline $\begin{array}{l}\text { Você já fez acordo ou parceria cedendo parte de seus } \\
\text { negócios em troca de tecnologia? }\end{array}$ & $15(71,4)$ & $6(28,6)$ & \\
\hline
\end{tabular}

Pergunta 39: Já trabalhou ou trabalha para o governo ou estatais ?

Pergunta 40: Se a resposta anterior foi afirmativa, o acesso à tecnologia foi.......

Pergunta 41: Já trabalhou ou trabalha para multinacionais?

Pergunta 42: Se a resposta anterior foi afirmativa, o acesso à tecnologia foi....... 
O trabalho com empresas do governo é praticamente inexistente, enquanto que o trabalho com multinacionais é praticamente extensivo a todos os pesquisados. Em todas as questões referentes a estes aspectos, não houve indicação de problemas quanto ao acesso às informações técnicas. Apenas um caso isolado indica dificuldade de acesso à tecnologia.

Tabela 25:Fornecimento a estatais e multinacionais e acesso à tecnologia.

\begin{tabular}{|c|c|c|c|c|c||}
\hline & Sim & Como sub fornecedor & \multicolumn{2}{|c|}{ Não / Nunca } \\
\hline $\begin{array}{c}\text { Já trabalhou ou trabalha para o } \\
\text { governo e/ou estatais? }\end{array}$ & $5(23,8)$ & \multicolumn{2}{|c|}{$1(4,8)$} & \multicolumn{2}{|c|}{$15(71,4)$} \\
\hline $\begin{array}{c}\text { Caso sua resposta anterior tenha sido } \\
\text { sim (exclusivamente), você achou } \\
\text { que o acesso à tecnologia foi: }\end{array}$ & Estimulado & Facilitado & Dificultado & Negado & Desnecessário \\
\hline $\begin{array}{c}\text { Já trabalhou ou trabalha para } \\
\text { multinacionais? }\end{array}$ & $19(90,5)$ & $1(16,7)$ & $1(16,7)$ & $1(4,8)$ & \multicolumn{2}{|c|}{$1(4,8)$} \\
\hline $\begin{array}{c}\text { Caso sua resposta anterior tenha sido } \\
\text { sim (exclusivamente), você achou } \\
\text { que o acesso à tecnologia foi: }\end{array}$ & $8(40,0)$ & $8(40,0)$ & $1(5,0)$ & Nunca \\
\hline \hline
\end{tabular}

\subsubsection{Parte 4 - Mecanismos de Implementação}

Neste item são avaliados aspectos referentes a planejamentos (budget), registros de alteração, documentação de processos e equipamentos de apoio, conforme segue.

Pergunta 43: Você elabora budgets para planejar seus gastos e despesas?

Pergunta 44: Caso sua resposta anterior tenha sido sim (exclusivamente), você planeja gastos ou investimentos com inovações tecnológicas?

\section{Tabela 26: Elaboração de orçamentos.}

\begin{tabular}{|l|c|c|c||}
\hline \hline & sim & não & parcialmente \\
\hline $\begin{array}{l}\text { Você elabora orçamentos (budget) formalmente, todos os anos, } \\
\text { para planejar seus gastos e despesas? }\end{array}$ & $16(76,2)$ & $3(14,3)$ & $2(9,5)$ \\
\hline $\begin{array}{l}\text { Caso sua resposta anterior tenha sido sim (exclusivamente), vocêe } \\
\text { planeja gastos ou investimentos com inovações tecnológicas? }\end{array}$ & $17(94,4)$ & $1(5,6)$ & \\
\hline
\end{tabular}

Pergunta 45: Prazo necessário para implementação de uma alteração de ferramental. 
Tabela 27: Prazo para implementação de alterações de ferramental.

\begin{tabular}{||l|c|c|}
\hline Prazo de implementação & Qtde & $\%$ \\
\hline Poucas semanas $(\approx 2)$ & 8 & 38,1 \\
\hline Imediatamente & 5 & 23,8 \\
\hline Ao redor de 1 mês & 3 & 14,3 \\
\hline Alguns dias (até 5 dias) & 2 & 9,5 \\
\hline Poucos meses $(\approx 2)$ & 2 & 9,5 \\
\hline De 3 a 6 meses & 1 & 4,8 \\
\hline Mais de 6 meses & 0 & 0 \\
\hline
\end{tabular}

Pergunta 46: As modificações de processo e/ou produto são documentadas?

Pergunta 47: Você tem documento específico que estabelece como registrar modificações?

Os dados estão reunidos em única tabela, a seguir.

Tabela 28: Documentação das modificações de processos e/ou produtos.

\begin{tabular}{|l|c|c||}
\hline Documentação das modificações & Qtd & $\%$ \\
\hline Sempre & 17 & 81,0 \\
\hline Às vezes & 3 & 14,3 \\
\hline Quando necessário (cliente pede) & 1 & 4,8 \\
\hline Muito pouco & 0 & 0 \\
\hline Nunca & 0 & 0 \\
\hline
\end{tabular}

\begin{tabular}{|c|c|c||}
\hline & Sim & não \\
\hline $\begin{array}{c}\text { Há documentação específica } \\
\text { para registro modificações }\end{array}$ & 18 & 3 \\
\hline$\%$ & 85,7 & 14,3 \\
\hline \hline
\end{tabular}

Pergunta 48: Que tipos de instrumentos de apoio sua empresa tem para projetos, alterações, desenvolvimentos, etc.?

As ferramentas de apoio ao projeto, desenvolvimento e produção apresentam larga escala de utilização, o que representa apoio à implementação da inovação tecnológica.

Tabela 29: Instrumentos de apoio à produção e desenvolvimento.

\begin{tabular}{|c|c|c|}
\hline Instrumentos de apoio & Quantidade & $\%$ \\
\hline CAE & 21 & 46,7 \\
\hline CAD & 11 & 24,4 \\
\hline CAM & 10 & 22,2 \\
\hline QFD & 2 & 4,4 \\
\hline Outros (citar) $*$ & 1 & 2,2 \\
\hline
\end{tabular}

Softwares específicos para projeto de módulos eletrônicos. 


\subsubsection{Parte 5 - Contexto interno}

Neste item verificamos a visão estratégica da empresa, em relação à inovação tecnológica, no que se refere ao seu contesto externo, ou seja, o segmento onde está inserida.

Pergunta 49: Em sua empresa, uma inovação é vista como:

Conforme a tabela a seguir, a inovação tecnológica não foi apontada por qualquer empresa como um objetivo; foi apontada pela maioria como oportunidade, apenas.

Tabela 30: Visão da empresa em relação à inovação tecnológica.

\begin{tabular}{|l|c|c|}
\hline Visão da empresa & Quantidade & $\%$ \\
\hline Questão de oportunidade. & 9 & 42,9 \\
\hline Estratégia de sobrevivência & 9 & 42,9 \\
\hline Motivo de procura & 3 & 14,3 \\
\hline Objetivo claro & 0 & 0 \\
\hline
\end{tabular}

Pergunta 50: a estrutura organizacional da sua empresa é funcional ou hierárquica?

Tabela 31: Estrutura organizacional.

\begin{tabular}{||c|c|c|}
\hline Estrutura & Quantidade & $\%$ \\
\hline Funcional & 16 & 76,2 \\
\hline Processo & 5 & 23,8 \\
\hline
\end{tabular}

Pergunta 51: Em sua opinião, sua empresa dá margem à criatividade dos colaboradores?

Pergunta 52: Existe método formal de coleta de novas idéias?

Existem dados positivos com relação à abertura para criatividade e treinamento de pessoal, mas não distintos, em termos de excelência, conforme as tabelas abaixo.

Tabela 32: Criatividade dos colaboradores, capital intelectual e geração de idéias.

\begin{tabular}{||l|c|c|c||}
\hline \hline $\begin{array}{l}\text { Em sua opinião, sua empresa dá margem à criatividade } \\
\text { de seus colaboradores? }\end{array}$ & $15(71,4)$ & $1(4,8)$ & $5(23,8)$ \\
\hline $\begin{array}{l}\text { Existe um método formal de coleta de novas idéias? } \\
\begin{array}{l}\text { Obs.: Considere isto algo superior a "caixa de } \\
\text { sugestões". Pense em termos de idéias novas! }\end{array}\end{array}$ & $8(38,1)$ & $13(61,0)$ & às \\
\hline
\end{tabular}


Pergunta 53: Sua empresa tem um programa formal de treinamento e formação do pessoal?

Tabela 33: Planejamento da formação do Capital Intelectual.

\begin{tabular}{|l|c|c||}
\hline & Sim & Não \\
\hline $\begin{array}{l}\text { Sua empresa tem um programa formal de treinamento e formação de seu } \\
\text { pessoal? }\end{array}$ & $\begin{array}{c}15 \\
(71,4)\end{array}$ & $\begin{array}{c}6 \\
(28,6)\end{array}$ \\
\hline
\end{tabular}

Pergunta 54: Como você classifica o processo de comunicação de sua empresa?

Tabela 34: Processo e velocidade de comunicação na empresa.

\begin{tabular}{||c|c|c||}
\hline Processo de Comunicação & Quantidade & $\%$ \\
\hline Ágil & 10 & 47,6 \\
\hline Instantâneo & 3 & 14,3 \\
\hline Lento & 3 & 14,3 \\
\hline Muito Ágil & 3 & 14,3 \\
\hline Falho & 2 & 9,5 \\
\hline Muito Lento & 0 & 0 \\
\hline Não existente & 0 & 0 \\
\hline \hline
\end{tabular}




\subsubsection{Discussão Geral sobre o Levantamento.}

Os dados coletados através dos questionários e as tabelas indicadas anteriormente serão analisados e discutidos nos parágrafos $a$ até $e$, de acordo com os respectivos parágrafos $a$ até $e$ do item 1.1 Objetivo do trabalho. Para efeito de avaliação dos resultados, em várias situações as empresas foram agrupadas de acordo com a formação de seu capital, ou seja, nacionais, de capital internacional e de capital misto. Este agrupamento permitiu verificar-se características bastante particulares ao tipo de capital da empresa.

\subsubsection{Parágrafo $a$}

"O grau de conhecimento destas empresas a respeito das principais fontes geradoras de inovação".

De acordo com o que foi visto no item 2.6.2.5 Alianças entre Empresas, e de acordo com o conceito de Tidd, J. et alii, as fontes de inovação mais adequadas, por ordem decrescente, são:

1. Universidades,

2. Alianças entre empresas,

3. Licenciamento tecnológico,

4. Consórcios de Pesquisa,

5. Clientes e Fornecedores.

Ainda de acordo com Tidd, J. et alii, estas mesmas fontes de inovação apresentam uma ordem crescente de criticidade, inversa à ordem de adequação. Sendo assim, a Universidade é considerada a fonte de inovação mais adequada, enquanto os clientes e fornecedores são considerados a fonte de inovação mais crítica. O que podemos observar com os dados obtidos no levantamento, e condensados na tabela 33, é que a fonte mais adequada de inovação (universidade) é exatamente uma das menos citadas pelas empresas pesquisadas. Por outro lado, fornecedores e clientes estão entre as fontes mais citadas, apesar de sua criticidade. Vale acrescentar que "fornecedores e clientes" são apontados como fontes somente para as empresas $100 \%$ nacionais ou $100 \%$ estrangeiras, provavelmente devido à transferência tecnológica, característica marcante na empresa de capital misto. 


\section{Tabela 35: Fontes de Inovações Tecnológicas}

\begin{tabular}{|c|c|c|c|c|c|c|c|c|c|}
\hline \multicolumn{10}{|c|}{$\begin{array}{l}\text { Em sua opinião, qual o modo mais adequado para se obter novas tecnologias? Cite } \\
\text { no máximo três. }\end{array}$} \\
\hline Formação do Capital & \multicolumn{3}{|c|}{$100 \%$ Nacional } & \multicolumn{3}{|c|}{$100 \%$ Estrangeiro } & \multicolumn{3}{|c|}{ Misto } \\
\hline $\begin{array}{ll}\text { Fonte tecnológica. } & \text { Opção }\end{array}$ & $1^{\mathrm{a}}$ & $2^{\mathrm{a}}$ & $3^{\circ}$ & $1^{\mathrm{a}}$ & $2^{\mathrm{a}}$ & $3^{\circ}$ & $1^{\mathrm{a}}$ & $2^{a}$ & $3^{\circ}$ \\
\hline Pesquisa e desenvolvimento próprios & 64,29 & 7,14 & & 75,0 & 25,0 & & 100 & & \\
\hline Joint ventures (uniões) & 14,29 & 21,43 & 7,14 & & 25,0 & & & 100 & \\
\hline Através dos fornecedores & 7,14 & 7,14 & 14,29 & & 25,0 & 25,0 & & & \\
\hline Através dos clientes & 7,14 & 14,29 & 7,14 & & & 25,0 & & & \\
\hline Pagando royalts (licenciamento) & 7,14 & 28,57 & 7,14 & & & & & & \\
\hline Engenharia reversa & & 14,29 & & 25,0 & & 25,0 & & & \\
\hline Leasing & & & & & & & & & \\
\hline Feiras ou eventos similares & & & 57,14 & & & 25,0 & & & 100 \\
\hline "Chupando" & & & & & 25,0 & & & & \\
\hline Universidades & & 7,14 & & & & & & & \\
\hline Pesquisa contratada (encomendada) & & & 7,14 & & & & & & \\
\hline Outras (cite, se quiser) & & & & & & & & & \\
\hline
\end{tabular}

É interessante observar que em todos os perfis de empresa, "feiras e eventos similares" aparecem como fonte; entretanto este tipo de evento é apenas um painel do que já está desenvolvido e em vias de ser encaminhado ao mercado, não se constituindo em fonte inovadora.

A "pesquisa e desenvolvimento próprios" foram apontados como a principal fonte inovadora, em todos os perfis empresariais, o que demonstra o reconhecimento da importância desta atividade. A avaliação da efetiva execução desta atividade será verificada nos parágrafos a seguir.

A figura a seguir nos dá uma visão geral das fontes de inovação lembradas pelos respondentes das empresas integrantes da amostra. 


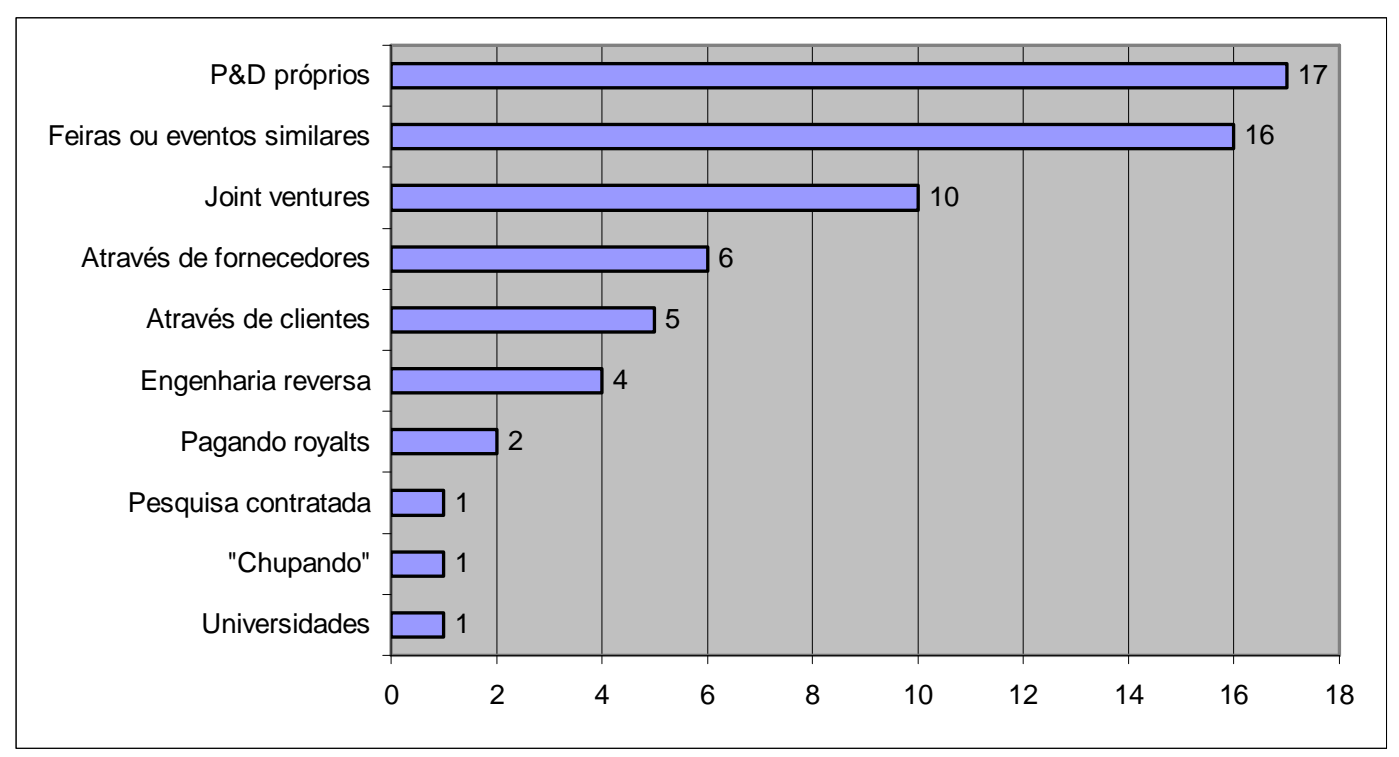

Figura 20: Fontes de inovação mais lembradas pelos pesquisados

Referente a "veículos indicadores de tendências tecnológicas", também observamos que a universidade é muito pouco lembrada, atrás de veículos, tais como: fornecedores, clientes, feiras e eventos, conforme indicado na tabela a seguir.

Tabela 36: Indicadores de Tendências Tecnológicas

\begin{tabular}{|l|c|c|c|c|c|c|c|c|c|}
\hline \multicolumn{8}{|c|}{$\begin{array}{c}\text { Em sua opinião, qual o melhor veículo para indicação de novas tendências } \\
\text { tecnológicas, ainda em sua fase inicial? Cite no máximo três. }\end{array}$} \\
\hline \multicolumn{1}{|c|}{ Formação do Capital } & \multicolumn{1}{c|}{$100 \%$ Nacional } & $100 \%$ Estrangeiro & \multicolumn{5}{c|}{ Misto } \\
\hline Veículo indicador & $1^{\mathrm{a}}$ & $2^{\mathrm{a}}$ & $3^{\mathbf{o}}$ & $1^{\mathrm{a}}$ & $2^{\mathrm{a}}$ & $3^{\mathbf{o}}$ & $1^{\mathrm{a}}$ & $2^{\mathbf{a}}$ & $3^{\mathbf{o}}$ \\
\hline Pesquisa de Mercado & 57,14 & 7,14 & & & 25,00 & 25,00 & 100,00 & & \\
\hline Pesquisa informal & 14,29 & & & 25,00 & & & & & \\
\hline P\&D internos & 7,14 & 7,14 & & 25,00 & & 25,00 & & & \\
\hline Literatura especializada & 7,14 & 7,14 & 14,29 & 25,00 & & & & & \\
\hline Feiras e eventos & 7,14 & 50,00 & 28,57 & & 25,00 & 25,00 & & 100,00 & \\
\hline Através dos fornecedores & 7,14 & & & & 25,00 & & & & \\
\hline Universidade & & & & 25,00 & & & & & \\
\hline Através dos clientes & & 21,43 & 28,57 & & 25,00 & 25,00 & & & 66,67 \\
\hline Através dos concorrentes & & & 14,29 & & & & & & \\
\hline Periódicos e publicações & & 7,14 & 14,29 & & & & & & 33,33 \\
\hline Associações de classe & & & & & & & & & \\
\hline Outros (especificar) & & & & & & & & & \\
\hline
\end{tabular}

Entretanto, considerando-se que as pequenas e médias empresas seguem a tendência tecnológica das grandes corporações multinacionais, e estas seguem o ambiente tecnológico dos governos de seus países, conforme Porter, M. (1990) citado em 2.5.1 A influência da política nacional, podemos considerar "fornecedores e clientes" como 
veículos efetivamente importantes, com influência até maior que "universidades", visto que estas não se constituem na fonte mais consultada por parte das empresas pesquisadas.

Sintetizando-se todas as respostas em um único gráfico, temos a figura abaixo, retratando o conhecimento dos empresários pesquisados, referente às fontes de inovação mais importantes.

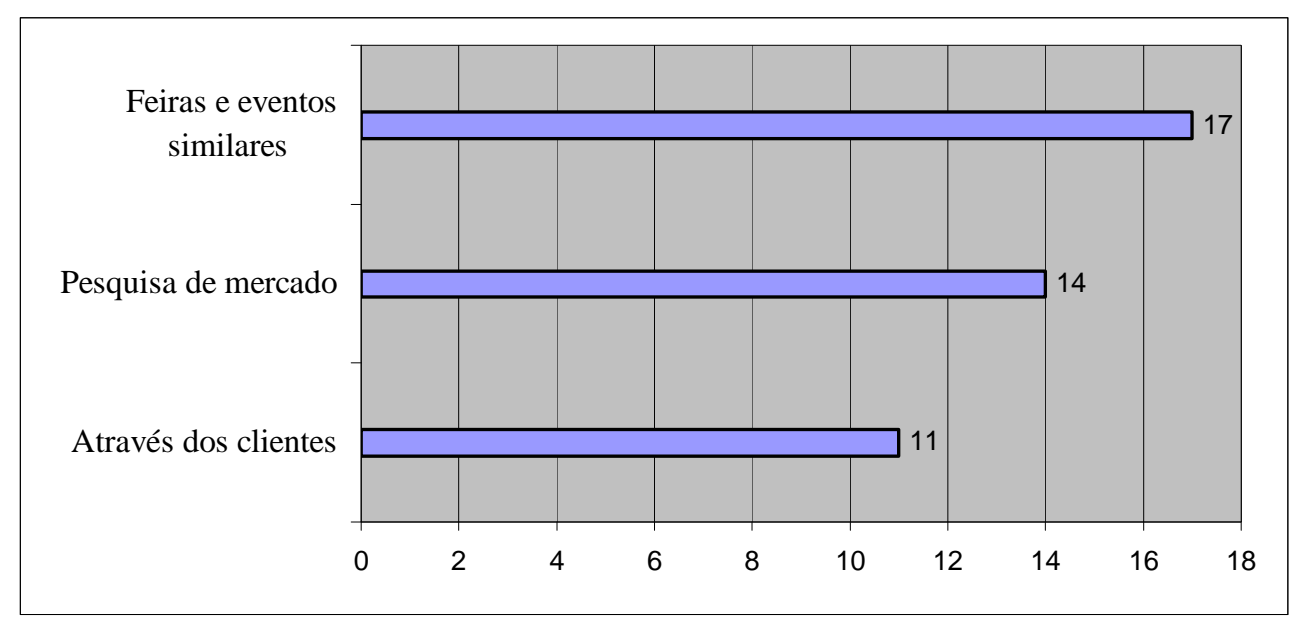

\section{Figura 21: Veículos indicadores de inovação mais lembrados pelos pesquisados}

Estes dados são confirmados pela afirmação de Eva Stal, integrante da Coordenadoria Executiva de Cooperação Universitária - USP, segundo a qual, somente grandes empresas sediadas no Brasil, usam o intercâmbio de conhecimento com universidades brasileiras, e dentre estas, essencialmente as subsidiárias das grandes empresas multinacionais (Siemens, Pirelli, Mercedes-Benz, entre outras) apresentam perfil de busca de novas tecnologias junto à universidade. Com este primeiro parágrafo podemos concluir que o grau de conhecimento sobre as principais fontes de inovação, por parte dos pequenos e médios empresários integrantes da amostra, não é satisfatório. 


\subsubsection{Parágrafo $b$}

“A importância do Capital Intelectual no processo de busca e incorporação de conhecimento destinado à inovação".

Nesta análise avaliamos a presença do engenheiro dentro da empresa, por ser o profissional agente da inovação. Além da avaliação da presença do engenheiro, foi avaliada também a política da empresa voltada ao Capital Intelectual como um todo.

Ao serem questionadas sobre "onde se concentraria a maior oportunidade de inovação para a empresa", permitido-se duas respostas para cada empresa consultada, obtivemos as respostas indicadas na figura abaixo:

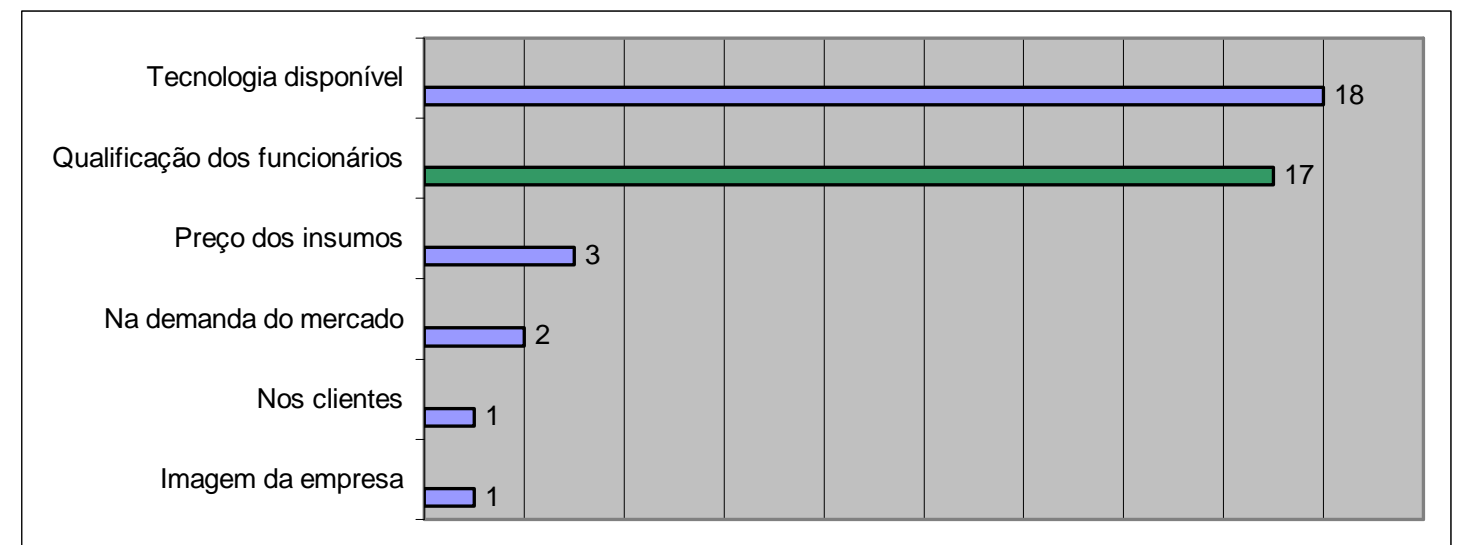

Figura 22: Localização das maiores oportunidades de inovação.

Outro aspecto abordado foi a respeito de "onde está situada a maior competência empresarial", permitindo-se um número espontâneo de respostas. Os dados estão sintetizados abaixo.

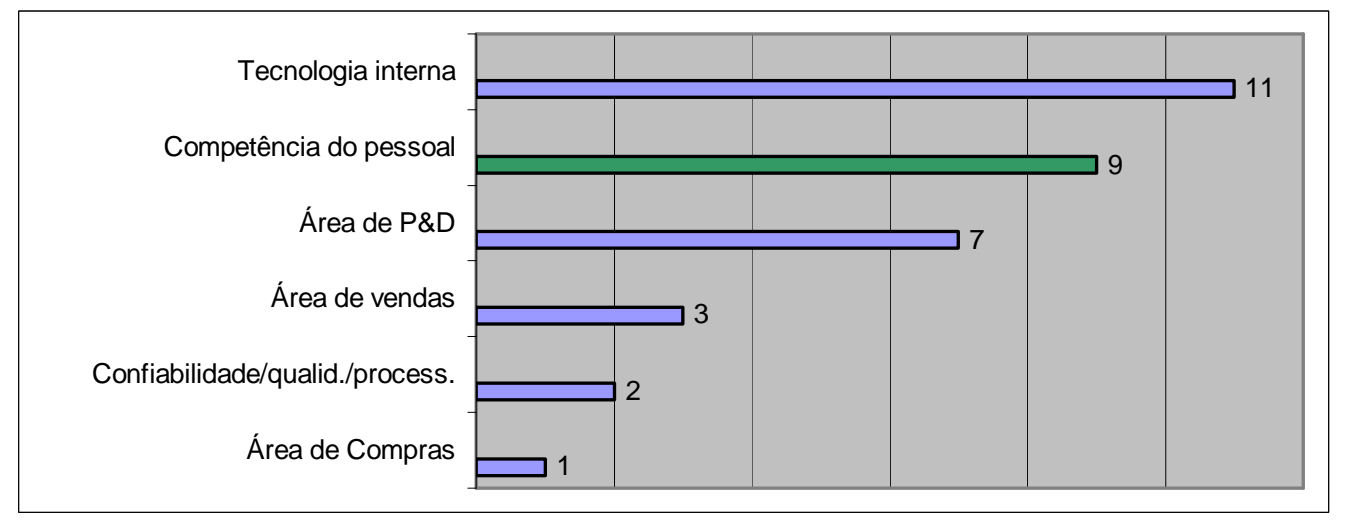

Figura 23: Localização das maiores competências empresariais. 
Os resultados indicam a "tecnologia" e o "capital intelectual" como os aspectos mais importantes, para as empresas integrantes da amostra. Entretanto, estes dados não se mostram consistentes quando confrontados com os resultados obtidos na avaliação da quantidade de engenheiros aplicados às indústrias pesquisadas e quando confrontados com a política aplicada ao Capital Intelectual, conforme veremos a seguir.

Para análise da aplicação dos engenheiros, agrupamos os dados de acordo com a natureza do capital das empresas pesquisadas, pois foi observado um comportamento diferente, em função da natureza do capital, conforme a tabela indicada a seguir.

Tabela 37: Distribuição da quantidade de colaboradores e engenheiros

\begin{tabular}{|c|c|c|c|c|c|c|c|c|}
\hline \multirow{2}{*}{\multicolumn{3}{|c|}{$\frac{\text { Natureza do Capital da Empresa }}{100 \% \text { nacional }}$}} & \multicolumn{4}{|c|}{$\begin{array}{l}\text { Quantidade de engenheiros na } \\
\text { empresa }\end{array}$} & \multicolumn{2}{|c|}{ informática } \\
\hline & & & \multirow{2}{*}{$\begin{array}{l}1 \mathrm{a} 3 \\
71,43\end{array}$} & \multirow{2}{*}{$\frac{4 \mathrm{a} 6}{14,29}$} & \multirow[t]{2}{*}{7 a 9} & \multirow{2}{*}{$\frac{10 \text { ou mais }}{7,14}$} & \multirow{2}{*}{$\begin{array}{c}\text { Número } \\
\text { de } \\
\text { colabor. }\end{array}$} & \multirow[b]{2}{*}{$\begin{array}{l}\text { Quant. de } \\
\text { engenh. }\end{array}$} \\
\hline $\begin{array}{r}66,67 \% \text { das e } \\
\text { da amos }\end{array}$ & tra & $\begin{array}{l}\text { \% de empr } \\
\text { Qtd de empr. }\end{array}$ & & & & & & \\
\hline \multirow{9}{*}{$\begin{array}{l}\text { Quantidade } \\
\text { total de } \\
\text { colaboradores }\end{array}$} & até 5 & 0 & & & & & Até 5 & 1 a 3 \\
\hline & 5 a 10 & 2 & 1 & 1 & & & 5 a 10 & 7 a 9 \\
\hline & 11 a 20 & 1 & 1 & & & & & \\
\hline & 21 a 40 & 3 & 2 & 1 & & & & \\
\hline & 41 a 60 & 1 & 1 & & & & & \\
\hline & 61 a 80 & 1 & 1 & & & & & \\
\hline & 81 a 100 & 2 & 2 & & & & & \\
\hline & 101 a 300 & 2 & 2 & & & & & \\
\hline & 301 a 450 & 2 & & & & 1 & & \\
\hline \multicolumn{3}{|c|}{$100 \%$ estrangeiro } & 1 a 3 & 4 a 6 & 7 a 9 & 10 ou mais & & \\
\hline \multicolumn{2}{|c|}{$\begin{array}{c}19,04 \% \text { das empresas } \\
\text { da amostra }\end{array}$} & $\begin{array}{l}\text { \% de empr } \\
\mathrm{n}^{\text {o de empr. }}\end{array}$ & & 25,00 & 25,00 & 50,00 & & \\
\hline \multirow{9}{*}{$\begin{array}{l}\text { Quantidade } \\
\text { total de } \\
\text { colaboradores }\end{array}$} & até 5 & 0 & & & & & & \\
\hline & 5 a 10 & 0 & & & & & & \\
\hline & 11 a 20 & 0 & & & & & & \\
\hline & 21 a 40 & 0 & & & & & & \\
\hline & 41 a 60 & 0 & & & & & & \\
\hline & 61 a 80 & 0 & & & & & & \\
\hline & 81 a 100 & 0 & & & & & & \\
\hline & 101 a 300 & 3 & & 1 & 1 & 1 & & \\
\hline & 301 a 450 & 1 & & & & 1 & & \\
\hline \multicolumn{3}{|c|}{$100 \%$ estrangeiro } & 1 a 3 & 4 a 6 & 7 a 9 & 10 ou mais & & \\
\hline \multicolumn{2}{|c|}{$\begin{array}{c}14,28 \% \text { das empresas } \\
\text { da amostra }\end{array}$} & $\begin{array}{l}\% \text { de empr } \\
\mathrm{n}^{\circ} \text { empresas }\end{array}$ & 33,33 & 33,33 & & 33,34 & & \\
\hline \multirow{9}{*}{$\begin{array}{l}\text { Quantidade } \\
\text { total de } \\
\text { colaboradores }\end{array}$} & até 5 & 0 & & & & & & \\
\hline & 5 a 10 & 0 & & & & & & \\
\hline & 11 a 20 & 0 & & & & & & \\
\hline & 21 a 40 & 2 & 1 & 1 & & & & \\
\hline & 41 a 60 & 0 & & & & & & \\
\hline & 61 a 80 & 0 & & & & & & \\
\hline & 81 a 100 & 0 & & & & & & \\
\hline & 101 a 300 & 1 & & & & 1 & & \\
\hline & 301 a 450 & 0 & & & & & & \\
\hline
\end{tabular}


Ao analisarmos a quantidade de engenheiros trabalhando na empresa, em função de sua quantidade total de colaboradores, verificamos que:

- As pequenas e médias empresas pesquisadas, de capital nacional, empregam menos engenheiros que as pequenas e médias empresas de capital estrangeiro ou misto,

- $71,43 \%$ das empresas de capital nacional integrantes da amostra, empregam entre 1 e 3 engenheiros,

- Nas empresas integrantes da amostra, de capital nacional e entre 100 e 300 funcionários, observamos que nenhuma emprega 10 ou mais engenheiros, fato observado em $25 \%$ e $33 \%$ das empresas de capital estrangeiro e misto, respectivamente,

- Podemos observar que as empresas da área de Software apresentam um perfil oposto ao observado nas demais. A taxa de aplicação de engenheiros é superior a $80 \%$, no caso das duas empresas pesquisadas.

Um levantamento efetuado pela FAPESP - Fundação de Amparo à Pesquisa do Estado de São Paulo, comparando a taxa de utilização de engenheiros e pesquisadores no nas empresas brasileiras ao mesmo índice de outros 7 países, indicou um resultado pouco animador, conforme a figura abaixo:

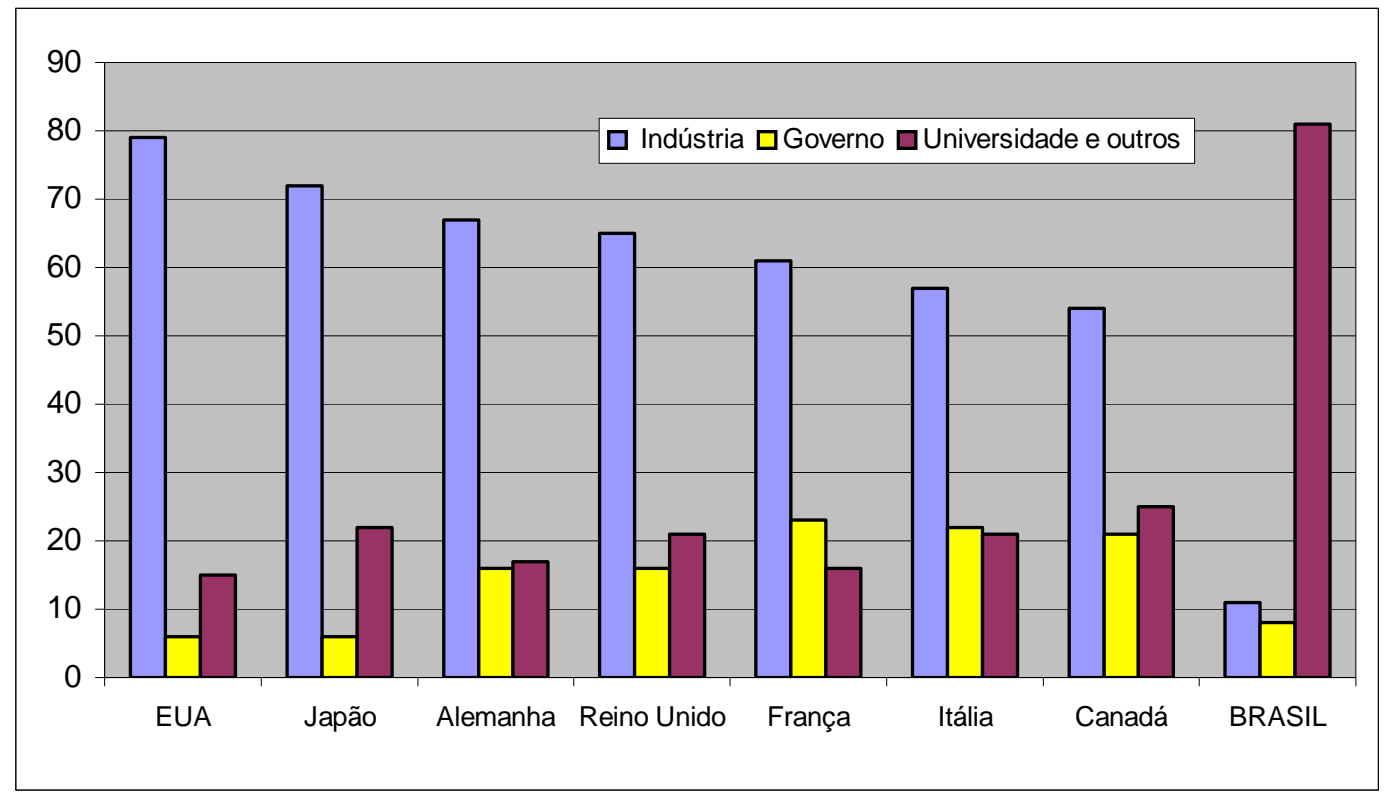

Figura 24: Distribuição (\%) de engenheiros e cientistas ativos em pesquisa e desenvolvimento 
Fonte: Fundação de Amparo à Pesquisa do Estado de São Paulo - FAPESP, obtida no jornal OESP, edição de 12 de agosto de 2001, seção Ciência e Tecnologia, página A14.

Esse estudo coordenado pela FAPESP mostrou que a quantidade de profissionais trabalhando efetivamente em pesquisa e desenvolvimento é muito pequena, representando apenas $0,11 \%$ da força de trabalho do país, enquanto este mesmo índice é da ordem de 0,80\% no Japão ou Estados Unidos, ou seja, quase oito vezes mais. Ao mesmo tempo, o estudo demonstrou que apenas $11 \%$ dos engenheiros no Brasil trabalham em indústrias, enquanto nos Estados Unidos, este índice é de $79 \%$.

Outro dado importante obtido por este levantamento da FAPESP, é a comparação da quantidade de engenheiros no Brasil e na Coréia do Sul, atuando em indústria, institutos de pesquisa e universidades. O resultado não é diferente do que foi apontado acima, conforme a figura a seguir:

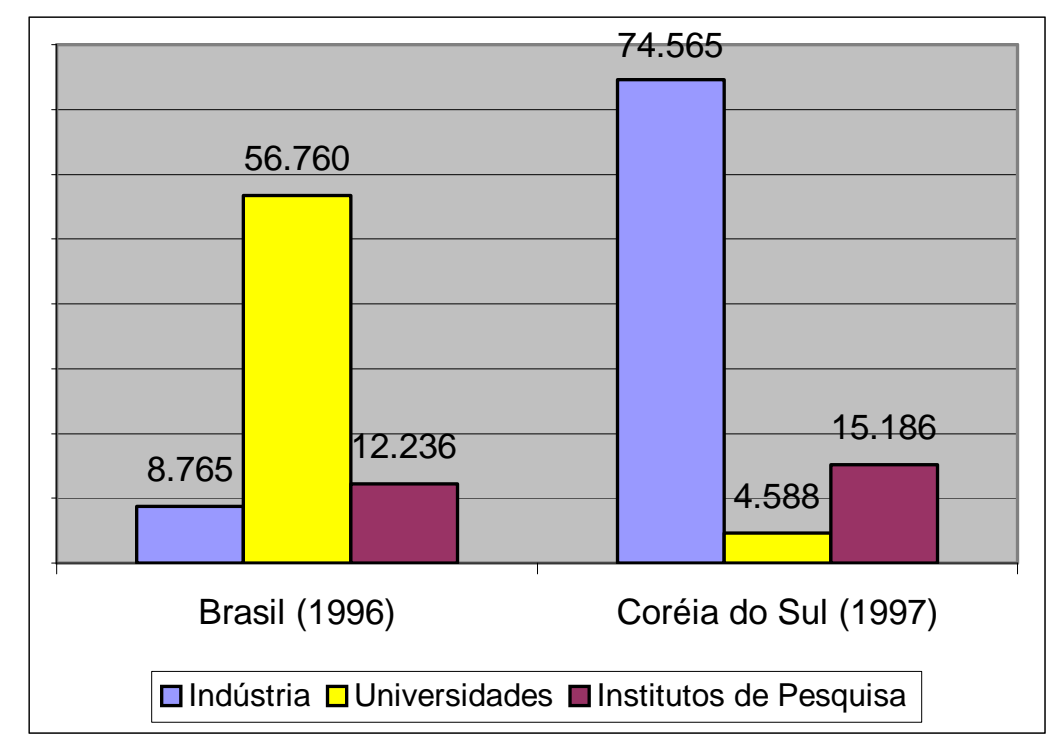

Figura 25: Distribuição de engenheiros e cientistas, em pesquisa e desenvolvimento - Brasil e Coréia do Sul

Fonte: Fundação de Amparo à Pesquisa do Estado de São Paulo - FAPESP, obtida no jornal OESP, edição de 12 de agosto de 2001, seção Ciência e Tecnologia, página A14.

É importante salientar que o estudo elaborado pela FAPESP refere-se à estatística de engenheiros e cientistas atuando na área de Pesquisa e Desenvolvimento, apenas, em todos os portes e segmentos industriais do Brasil. No caso do levantamento efetuado neste estudo, consideramos engenheiros atuando em qualquer área da empresa, e não apenas em Pesquisa e Desenvolvimento, o que torna o quadro destas empresas pesquisadas ainda menos favorável. 
Quanto à política das empresas da amostra, dirigidas ao Capital Intelectual, observamos os dados sintetizados no quadro abaixo, referentes a criatividade, coleta de idéias e formação de pessoal.

Tabela 38: Política voltada ao Capital Intelectual

\begin{tabular}{|c|c|c|c|c|}
\cline { 3 - 5 } \multicolumn{2}{c|}{} & \multicolumn{3}{c|}{ Formação do Capital da Empresa } \\
\cline { 3 - 5 } \multicolumn{2}{c|}{} & $100 \%$ nacional & $100 \%$ estrangeiro & Misto \\
\hline \multirow{2}{*}{$\begin{array}{c}\text { A empresa dá abertura à } \\
\text { criatividade dos colaboradores }\end{array}$} & Sim & $71,43 \%$ & $50,00 \%$ & $100,00 \%$ \\
\cline { 2 - 5 } & às vezes & $21,43 \%$ & $50,00 \%$ & \\
\cline { 2 - 5 } & Não & $7,14 \%$ & & \\
\hline $\begin{array}{c}\text { A empresa tem um método } \\
\text { formal de coleta de novas idéias. }\end{array}$ & Sim & $28,57 \%$ & $25,00 \%$ & $100,00 \%$ \\
\cline { 2 - 5 } & Não & $71,43 \%$ & $75,00 \%$ & \\
\hline $\begin{array}{c}\text { A empresa tem um programa formal } \\
\text { de treinamento e formação de pessoal }\end{array}$ & Sim & $57,14 \%$ & $100,00 \%$ & $100,00 \%$ \\
\cline { 2 - 5 } & Não & $42,86 \%$ & & \\
\hline
\end{tabular}

Os dados sintetizados nas figuras 22 e 23 foram confrontados com os dados da tabela 38, acima. As respostas dadas pelas empresas pesquisadas indicam que:

- É proporcionada abertura parcial à criatividade dos colaboradores, principalmente nas empresas de capital nacional e estrangeiro, integrantes da amostra,

- O processo de coleta de novas idéias é pouco difundido, especialmente entre as empresas de capital nacional ou estrangeiro, integrantes da amostra,

- Programas de formação e treinamento ocorrem em todas as empresas amostradas, de capital nacional ou misto, porém apenas em pouco mais de $50 \%$ das empresas de capital nacional, integrantes da amostra.

Isto indica um perfil incongruente dentro da amostra de empresas pesquisadas. A baixa aplicação de profissionais de engenharia, fundamentais ao processo de inovação, não é condizente com a importância dada aos itens "qualificação dos funcionários" e até mesmo com a importância dada a "tecnologia disponível”.

Com os dados acima, podemos concluir que, entre as empresas integrantes da amostra, a utilização da mão de obra de engenharia ocorre em níveis insatisfatórios. Ao mesmo tempo podemos constatar que o investimento moral e financeiro dirigido ao capital intelectual da empresa também é insatisfatório. Ambos os aspectos comprometem significativamente o processo de inovação tecnológica dessas empresas. 


\subsubsection{Parágrafo $c$}

"O impacto que este processo de inovação apresenta sobre a vantagem competitiva das empresas".

A análise do impacto do processo de inovação foi avaliada através da participação e evolução do mercado, abertura econômica e exportação, conforme sintetizado na tabela 39 a seguir. Novamente, as empresas pesquisadas foram classificadas de acordo com a natureza de seu capital, por razões já expostas.

Com relação à evolução da parcela de mercado foi observado que:

- Dentre as empresas pesquisadas, de capital nacional, a evolução de mercado apresenta tendência linear em relação ao percentual de investimento,

- As empresas de capital nacional que indicaram perda acentuada de mercado, são as que declararam menos de $1 \%$ do faturamento,

- Somente as empresas de capital nacional, integrantes da amostra, apresentaram perda, leve ou acentuada, de mercado,

- Entre as empresas de capital estrangeiro, 25\% apontam manutenção do mercado enquanto $75 \%$ declararam ganho de mercado acentuadamente.

- Todas as empresas de capital misto declararam ganho de mercado, levemente ou acentuadamente.

Com relação ao impacto da abertura de mercado, observamos que:

- Para as empresas de capital nacional, integrantes da amostra, a abertura de mercado foi negativa e muito negativa em $85 \%$ dos casos,

- Para as empresas de capital estrangeiro, integrantes da amostra, a abertura não apresentou impacto qualquer em 50\% dos casos, enquanto para os outros $50 \%$ a abertura econômica teve impacto bom,

- Para as empresas de capital misto, a abertura foi um evento considerado muito bom. 
Tabela 39 : Impacto do processo de inovação versus vantagem competitiva.

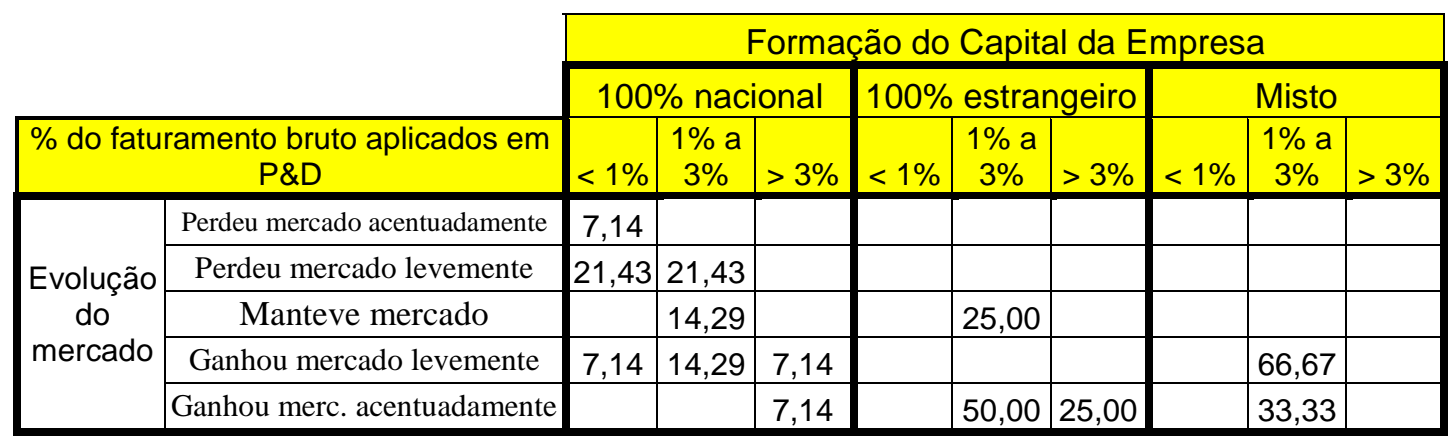

\begin{tabular}{|c|c|c|c|c|c|c|c|}
\hline \multirow{6}{*}{$\begin{array}{l}\text { Impacto } \\
\text { da } \\
\text { abertura } \\
\text { do } \\
\text { mercado } \\
\text { brasileiro }\end{array}$} & Muito Negativo & 7,14 & 7,14 & & & & \\
\hline & Negativo & 28,57 & 28,57 & 14,29 & & & \\
\hline & Indiferente & & & & 25,00 & 25,00 & \\
\hline & Bom & & 14,29 & & 50,00 & & \\
\hline & Muito bom & & & & & & 100,00 \\
\hline & Excelente & & & & & & \\
\hline
\end{tabular}

\begin{tabular}{|l|c|c|c|c|c|c|c|c|c|c|}
\hline \multirow{2}{*}{$\begin{array}{l}\text { Quanto } \\
\text { exporta }\end{array}$} & Não exporta & 14,29 & 14,29 & 7,14 & & & & & & \\
\cline { 2 - 12 } & Até 10\% do faturamento & 21,43 & 28,57 & 7,14 & & 75,00 & 25,00 & & & \\
\cline { 2 - 11 } & 11 a 20\% do faturamento & & 7,14 & & & & & 100,00 & \\
\hline
\end{tabular}

\begin{tabular}{|c|c|c|c|c|c|c|c|}
\hline \multirow{6}{*}{$\begin{array}{c}\text { Sua } \\
\text { parcela } \\
\text { de } \\
\text { mercado }\end{array}$} & Menos de $10 \%$ & 28,57 & 14,29 & & 25,00 & & \\
\hline & De 10 a $20 \%$ & & 21,43 & 7,14 & & & 33,33 \\
\hline & De 21 a $30 \%$ & & 7,14 & & & & 33,33 \\
\hline & De 31 a $50 \%$ & & & & 50,00 & & 33,33 \\
\hline & Mais de $51 \%$ & 7,14 & 7,14 & 7,14 & & 25,00 & \\
\hline & Não sei & & & & & & \\
\hline
\end{tabular}

Referente ao aspecto "exportação", os resultados são proporcionais aos dados anteriores, ou seja:

- A atividade exportadora não existe em 33,34\% das empresas de capital nacional, integrantes da amostra.

- A exportação reponde por até $10 \%$ do faturamento em $57,14 \%$ das empresas de capital nacional e em $100 \%$ das empresas de capital estrangeiro.

- Nas empresas de capital misto, a exportação responde por parcelas maiores do faturamento, entre $11 \%$ e $20 \%$ do faturamento.

- Em todos os casos, o volume exportado não é significativo

Com relação à parcela de mercado, podemos constatar que as empresas de capital nacional pesquisadas, com participação de mercado acima de 50\%, declararam ter sido 
negativo ou muito negativo o impacto de abertura de mercado. Ao mesmo tempo, empresas de capital estrangeiro ou misto, com participação de mercado variando de menos de $10 \%$ até mais de $50 \%$, declararam ter sido muito bom o impacto de abertura de mercado ao mesmo tempo em que declaram ganho leve ou acentuado de mercado.

Podemos deduzir que:

As empresas pesquisadas, de capital estrangeiro ou misto apresentaram desempenho de mercado superior às empresas de capital nacional, possivelmente devido ao aporte de suas matrizes ou coligadas com relação à transferência ou geração de inovações tecnológicas, o que lhes permite ganho de fatias de mercado, de acordo com Reichfeld, E.F. (1996), conforme comentado no item 2.1.5 A vantagem competitiva gerada pela inovação. Provavelmente este mesmo aspecto tem relação direta com o impacto que as empresas tiveram com a abertura de mercado, cujas respostas seguem o mesmo padrão observado no aspecto "ganho de mercado".

Porém, mesmo nas empresas de capital misto, o volume exportado ainda é incipiente.

\subsubsection{Parágrafo $d$}

O grau de conhecimento das pequenas e médias empresas quanto às ferramentas de trabalho associadas ao processo de inovação,

Neste parágrafo procuramos avaliar o grau de conhecimento e aplicação das ferramentas da qualidade no processo produtivo, ferramentas para avaliação das necessidades dos clientes e ferramentas de apoio aos processos de inovação e manufatura.

Pudemos observar que:

- As ferramentas estatísticas de apoio ao processo produtivo, tais como o CEP, Ishikawa e histogramas são utilizados de modo amplo e, provavelmente, dentro das necessidades de cada tipo de empresa. Por exemplo, as empresas de capital mistos, integrantes da amostra, estão entre as que usam a menor variedade de ferramentas estatísticas, limitando-se a coletas de dados no processo e histogramas, aparentemente, suficientes às suas necessidades.

- As ferramentas de avaliação das necessidades do cliente também são amplamente utilizadas pelas empresas integrantes da amostra. De acordo com os 
dados levantados, ferramentas tais como DFQ (Desdobramento da Função Qualidade), pesquisa de mercado, internet e linha 0800 são utilizadas amplamente.

Tabela 40: Ferramentas de apoio o processo de inovação

\begin{tabular}{|c|c|c|c|c|}
\hline & & \multicolumn{3}{|c|}{ Formação do Capital da empresa } \\
\hline & & $\begin{array}{c}100 \% \\
\text { nacional }\end{array}$ & $\begin{array}{c}100 \% \\
\text { estrangeiro }\end{array}$ & Misto \\
\hline \multirow{8}{*}{$\begin{array}{c}\text { Ferramentas } \\
\text { estatísticas } \\
\text { utilizadas no } \\
\text { processo de } \\
\text { produção e } \\
\text { desenvolvimento }\end{array}$} & Coleta de dados de processo & $50,00 \%$ & $75,00 \%$ & $100,00 \%$ \\
\hline & Cartas de CEP & $50,00 \%$ & $50,00 \%$ & \\
\hline & Análise de Pareto & $33,33 \%$ & $50,00 \%$ & \\
\hline & Delineamento de experimentos & & $25,00 \%$ & \\
\hline & Diagrama de Correlação & & $25,00 \%$ & \\
\hline & Diagrama Ishikawa & $33,33 \%$ & $75,00 \%$ & \\
\hline & Histogramas & $16,67 \%$ & $75,00 \%$ & $100,00 \%$ \\
\hline & Nenhuma & $16,67 \%$ & & \\
\hline \multirow{6}{*}{$\begin{array}{l}\text { Métodos de } \\
\text { avaliação das } \\
\text { necessidades } \\
\text { dos clientes. }\end{array}$} & Pesquisa de mercado & $33,33 \%$ & $50,00 \%$ & $100,00 \%$ \\
\hline & Internet & $66,67 \%$ & $25,00 \%$ & $100,00 \%$ \\
\hline & Outros: Dados estatísticos do cliente & & $50,00 \%$ & $100,00 \%$ \\
\hline & Linha telefônica 0800 & $33,33 \%$ & $25,00 \%$ & \\
\hline & QFD & $16,67 \%$ & $50,00 \%$ & \\
\hline & Método Delphi & & & \\
\hline \multirow{4}{*}{$\begin{array}{c}\text { Instrumentos de apoio } \\
\text { para projetos, } \\
\text { desenvolvimentos e } \\
\text { manufatura. }\end{array}$} & CAD - Projeto auxiliado por computador & $100,00 \%$ & $100,00 \%$ & $100,00 \%$ \\
\hline & CAE - Execução auxiliada por computad. & $50,00 \%$ & $75,00 \%$ & $100,00 \%$ \\
\hline & CAM - Manufatura auxiliada por comput. & $33,33 \%$ & $50,00 \%$ & $100,00 \%$ \\
\hline & QFD - Desdobramento da Função Qualid. & & $25,00 \%$ & \\
\hline
\end{tabular}

- As ferramentas de apoio aos processos de inovação, tais como CAD, CAE e CAM também são amplamente utilizadas, de acordo com as respostas das empresas pesquisadas.

Neste parágrafo podemos concluir que as ferramentas de apoio ao processo de inovação estão difundidas entre os diversos tipos de empresas integrantes da amostra, não apresentando uma diferença significativa entre estas.

\subsubsection{Parágrafo $e$}

"As práticas gerenciais das pequenas e médias empresas relacionadas ao processo de inovação de produtos e processos".

Neste parágrafo serão analisados os aspectos referentes à gestão conduzida pelas empresas integrantes da amostra, no que se refere ao processo de inovação. 
O primeiro aspecto abordado refere-se ao processo de benchmarking e a busca da satisfação do cliente, no início do processo de inovação, conforme sintetizado na tabela abaixo, onde podemos observar que:

- A tecnologia envolvida é reconhecida de forma unânime, porém não majoritária, pelas empresas pesquisadas,

- Preço ainda é o aspecto mais valorizado,

- A atividade de benchmarking foi restrita a 50\% das empresas pesquisadas, não se revelando uma prática usual entre as empresas pesquisadas. A análise direta do produto ainda é o procedimento mais utilizado.

Tabela 41: Visão de Benchmarking e conhecimento do cliente

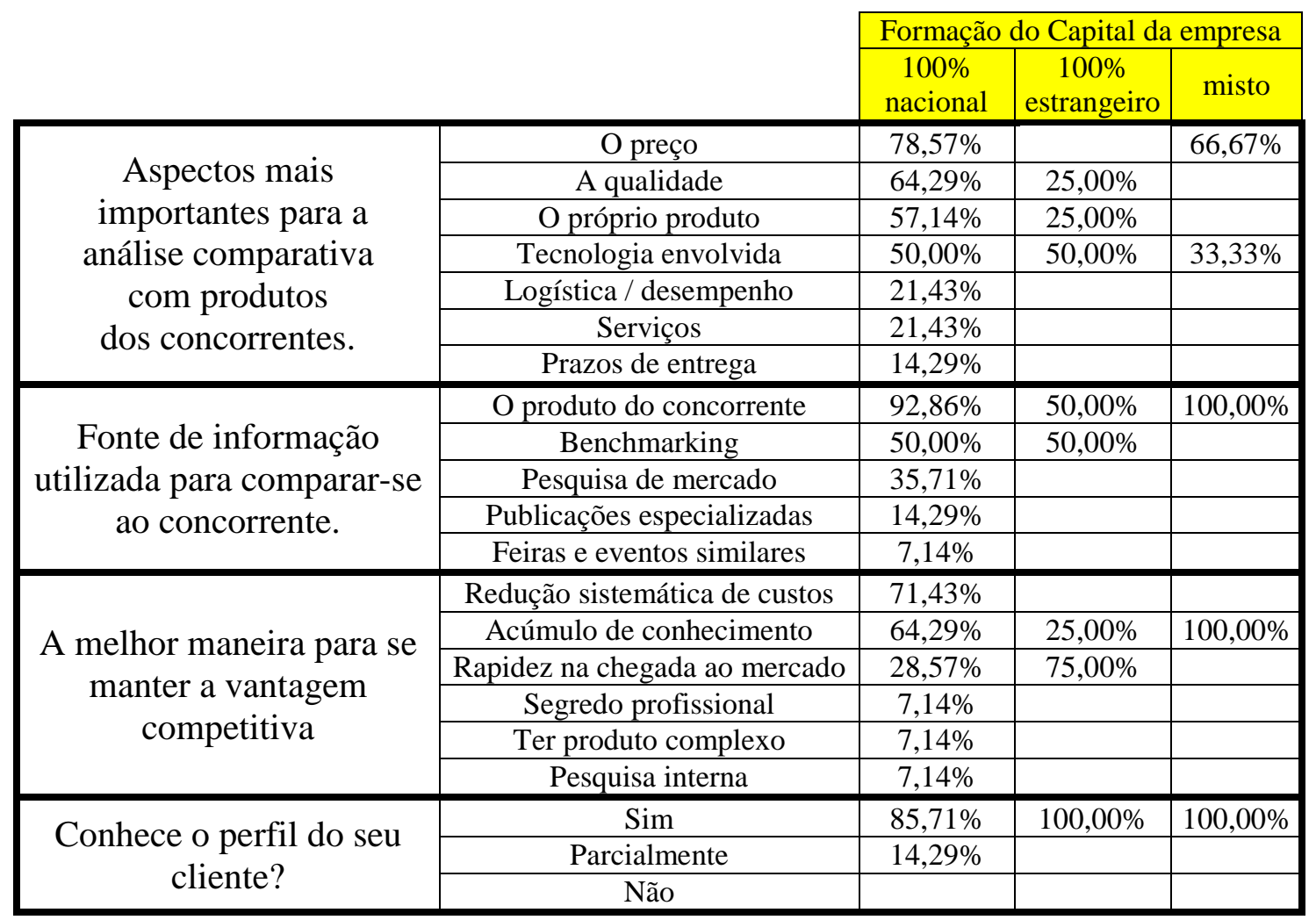

- Confirmando um dado anterior, o aspecto "custo" é citado como fundamental à vantagem competitiva, porém, o acúmulo de conhecimento foi apontado como importante para a vantagem competitiva em todos os segmentos da amostra, ainda que em proporções muito diversas. Neste aspecto observou-se que apenas as empresas de capital nacional apontaram o segredo profissional como um aspecto importante, indicando uma tendência dessas empresas ao isolacionismo. 
Este aspecto foi observado durante o processo de pesquisa no campo. A obtenção das respostas correspondeu a uma pequena fração das consultas.

- Praticamente todas as empresas da amostra conhecem o perfil de seus clientes.

O segundo aspecto abordado neste parágrafo refere-se à estrutura formal e à documentação utilizada como apoio ao processo de inovação. O objetivo é verificar a cultura da empresa quanto ao armazenamento de informações, fundamental ao processo de inovação, de acordo com Tidd, J. (1996), conforme indicados na tabela abaixo.

Tabela 42: Estrutura e documentação de apoio à inovação

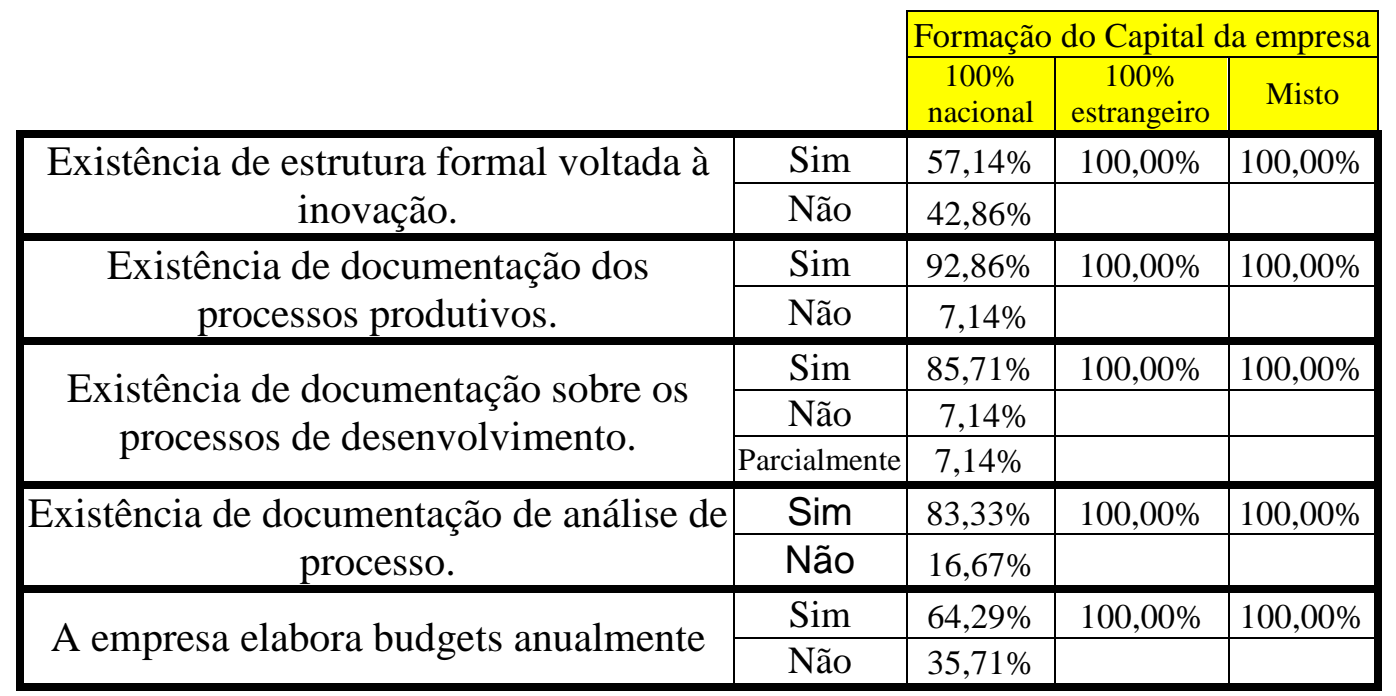

Podemos observar que, entre as empresas da amostra, a existência de estrutura formal de apoio à inovação é insatisfatória entre as empresas de capital nacional. Pouco mais da metade destas contam com estrutura voltada à inovação.

A prática da documentação dos processos de desenvolvimento e produção está bastante difundida, mas ainda desfavorável ao capital nacional.

O planejamento financeiro da empresa (budget) é prática corrente nas empresas de capital estrangeiro ou misto, integrantes da amostra, porém não praticado por mais de $35 \%$ das empresas de capital nacional. Este dado indica comprometimento ao processo de inovação das empresas de capital nacional amostradas, visto que este processo está relacionado diretamente à gestão financeira da empresa. 
O terceiro e último aspecto verificado neste parágrafo refere-se à parceria, transferência de conhecimento e visão estratégica da inovação. Os dados coletados indicam que:

- O trabalho em parceria com o fornecedor ocorre em todos os segmentos de empresas da amostra, ainda que em diferentes proporções.

- A parceria com estatais é muito reduzida, e nos casos em que ocorre, a transferência da tecnologia é disponibilizada, na maioria dos casos. Vale observar que, em todos os casos de empresas estrangeiras da amostra, que mantiveram algum vínculo com estatais/governo, a tecnologia foi desnecessária, diferentemente das empresas nacionais, que mostraram evidência de buscar a tecnologia.

Tabela 43: Parceria, transferência e visão da inovação

\begin{tabular}{|c|c|c|c|c|}
\hline & & & & \\
\hline & & \multicolumn{3}{|c|}{ Formação do Capital da empresa } \\
\hline & & $\begin{array}{c}100 \% \\
\text { nacional }\end{array}$ & \begin{tabular}{|c|}
$100 \%$ \\
estrangeiro \\
\end{tabular} & Misto \\
\hline \multirow{3}{*}{$\begin{array}{l}\text { Trabalho em parceria com } \\
\text { o fornecedor }\end{array}$} & Sim & $71,43 \%$ & $75,00 \%$ & $100,00 \%$ \\
\hline & parcialmente & $21,43 \%$ & $25,00 \%$ & \\
\hline & Não & $7,14 \%$ & & \\
\hline \multirow{3}{*}{$\begin{array}{c}\text { Já trabalhou ou trabalha } \\
\text { para o governo ou estatais? }\end{array}$} & Não / nunca & $66,67 \%$ & $75,00 \%$ & $100,00 \%$ \\
\hline & Sim & $28,57 \%$ & $25,00 \%$ & \\
\hline & Como sub fornecedor & $7,14 \%$ & & \\
\hline \multirow{5}{*}{$\begin{array}{c}\text { Durante este trabalho para } \\
\text { o governo ou estatais, o } \\
\text { acesso à tecnologia foi }\end{array}$} & Estimulado & $60,00 \%$ & & \\
\hline & Facilitado & $20,00 \%$ & & \\
\hline & Dificultado & $20,00 \%$ & & \\
\hline & Negado & & & \\
\hline & Desnecessário & $16,67 \%$ & $100,00 \%$ & \\
\hline \multirow{3}{*}{$\begin{array}{c}\text { Já trabalhou ou trabalha } \\
\text { para multinacionais? }\end{array}$} & $\operatorname{Sim}$ & $85,71 \%$ & $100,00 \%$ & $100,00 \%$ \\
\hline & Como sub fornecedor & $7,14 \%$ & & \\
\hline & Nunca & $7,14 \%$ & & \\
\hline \multirow{5}{*}{$\begin{array}{l}\text { Durante este trabalho para } \\
\text { multinacionais, o acesso à } \\
\text { tecnologia foi: }\end{array}$} & Facilitado & $53,85 \%$ & $25,00 \%$ & \\
\hline & Estimulado & $23,08 \%$ & $50,00 \%$ & $100,00 \%$ \\
\hline & Desnecessário & $15,38 \%$ & $25,00 \%$ & \\
\hline & Dificultado & $7,69 \%$ & & \\
\hline & Negado & & & \\
\hline \multirow{4}{*}{$\begin{array}{l}\text { Visão da inovação dentro } \\
\text { da empresa }\end{array}$} & Estratégia de sobrevivência & $50,00 \%$ & $25,00 \%$ & $100,00 \%$ \\
\hline & Questão de oportunidade & $35,71 \%$ & $50,00 \%$ & \\
\hline & Motivo de procura & $14,29 \%$ & $25,00 \%$ & \\
\hline & Objetivo claro & & & \\
\hline
\end{tabular}


- A parceria com as multinacionais é mais freqüente, e estas se demonstram mais facilitadoras no acesso à tecnologia, de acordo com as empresas amostradas.

- O único caso em que uma empresa apontou dificuldade na obtenção de tecnologia, junto a multinacionais, ocorreu em empresa nacional, fabricante de um item com maior agregação tecnológica (alto falantes para indústria fonográfica). No geral, as multinacionais mostram-se estimuladoras.

- A inovação tecnológica é declarada unanimemente como questão de oportunidade ou estratégia de sobrevivência, porém, surpreendentemente não é considerada um objetivo claro para nenhuma das empresas pesquisadas.

Referente ao parágrafo $e$, podemos concluir que a prática de avaliação dos produtos, através do benchmarking, ainda não é usual entre as empresas pesquisadas, o que pode comprometer a fase inicial do processo de inovação de produtos ou processos. Apesar de dados anteriores terem demonstrado a deficiência na cultura da inovação, o acúmulo de conhecimento foi apontado como o aspecto mais importante para a manutenção da vantagem competitiva. Neste item de avaliação, somente empresas nacionais integrantes da amostra e em quantidade minoritária, apontaram o segredo profissional como importante para a manutenção da vantagem competitiva, indicando tendência ao isolacionismo, conforme já comentamos.

Com relação à estrutura de apoio e documentação voltados à inovação, a maioria das empresas amostradas declara ter estrutura de apoio e prática de documentação dos procedimentos associados à inovação. Os casos (em minoria) onde não são apontados dados referentes a estrutura de apoio e documentação restringem-se às empresas de capital nacional.

O último dado levantado refere-se às parcerias. De acordo com declaração das empresas pesquisadas, o governo e/ou estatais, são parceiros pouco freqüentes; e quando ocorrem, não se demonstram fundamentais no acesso à tecnologia. Por outro lado, as empresas multinacionais são parceiras freqüentes e de acordo com as empresas pesquisadas, se demonstram estimuladoras ou facilitadoras no acesso à tecnologia.

Apesar de muitos fatos descritos acima serem restritivos ao processo de inovação, esta apresenta caráter estratégico para as empresas integrantes da amostra. 


\section{Capítulo 5 - Conclusão}

\section{$\underline{5.1 \text { Conclusões Finais }}$}

A inovação tecnológica baseia-se em quatro pilares de sustentação: a fonte de inovação, o capital intelectual, o processo de gestão da inovação, incluindo-se aí as ferramentas de apoio ao processo inovador, e o investimento.

Sendo a inovação tecnológica fundamental à vantagem competitiva das empresas, conforme abordamos no item 2.1.5, fundamentados por Reichfeld, E.F. e Terra, J.C.C., o correto equilíbrio entre estes pilares torna-se fundamental ao processo inovador. Entretanto, o que pudemos constatar dentro das empresas integrantes da amostra, não é revelador de um cenário muito otimista.

O acesso às fontes de inovação e a identificação dos veículos indicadores das novas tendências tecnológicas são pontos fundamentais ao empresário industrial. Entretanto, conforme constatamos na amostra, este conhecimento ainda não foi incorporado à cultura do pequeno e médio empresário, comprometendo o processo de inovação dessas indústrias.

O capital intelectual não está fortalecido dentro das empresas amostradas, apesar deste ser reiteradamente apontado como fundamental e como depositário das maiores oportunidades tecnológicas das empresas consultadas. O uso da mão de obra especializada, notadamente engenheiros, não atinge patamares satisfatórios, o que compromete a absorção e manutenção do processo de inovação tecnológica, conforme fundamentado por dados da FAPESP.

As ferramentas voltadas à inovação, a estrutura de apoio e o processo de documentação declarados pelas empresas amostradas, indicam uma utilização ampla, o que reforça o sistema de gestão voltado à inovação. Porém, a aplicação de metodologias voltadas à inovação, como o Benchmarking, e a visão que os empresários tem a respeito da inovação, estão longe de um nível satisfatório. 
Quanto ao investimento, constatamos que o percentual do faturamento bruto destinado ao processo de inovação, declarado pelas empresas, está abaixo de $1 \%$ em $15 \%$ dos casos, entre 1 e $3 \%$ do faturamento bruto em $70 \%$ dos casos e em $3 \%$ do faturamento bruto em $15 \%$ dos casos. Os valores poderiam até ser considerados satisfatórios, porém careceria um maior detalhamento do que é considerado item de investimento em inovação, sob a ótica dos empresários, o que não foi o objeto principal desta pesquisa. Entretanto, dados do OECD, não situam o setor privado brasileiro em lugar honroso no que se refere ao percentual de investimento em relação ao PIB, conforme abaixo:

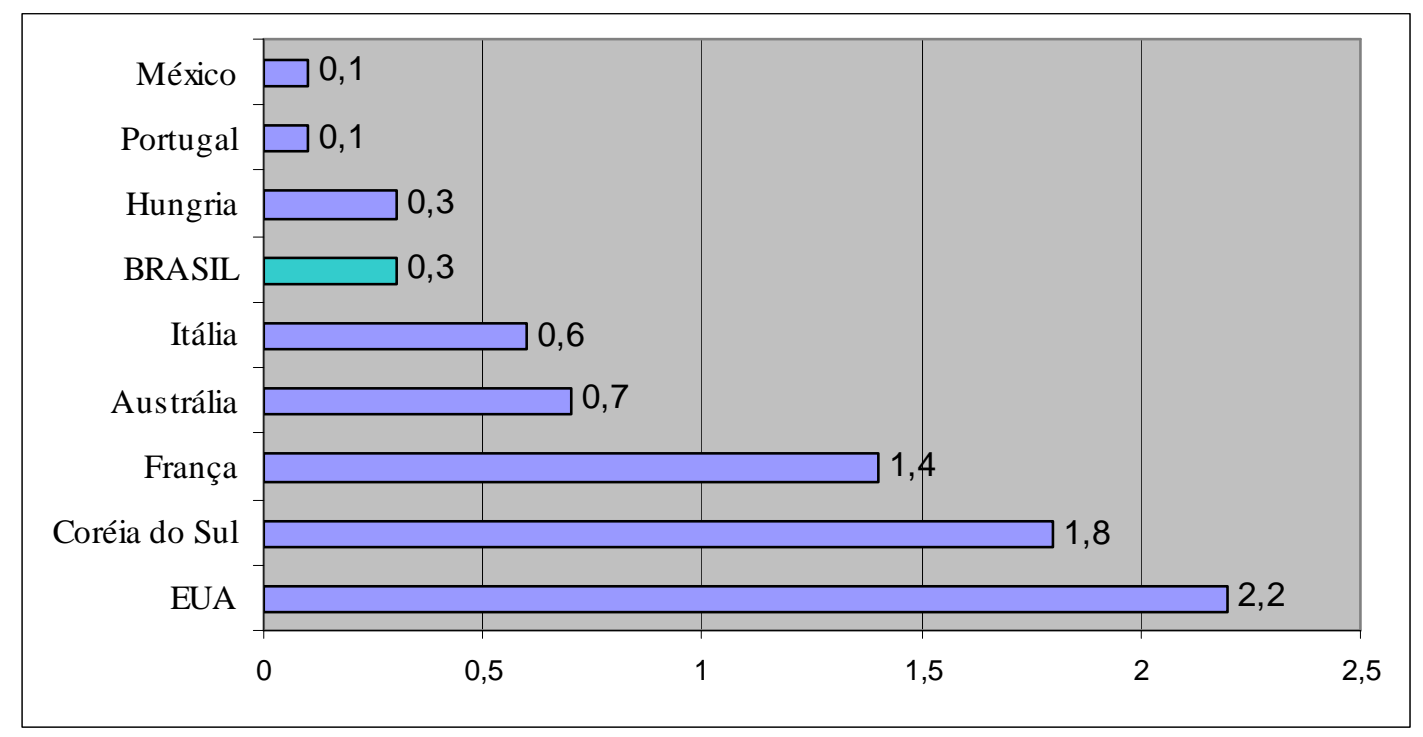

Figura 26: Gasto em P\&D das empresas privadas, como \% do PIB

Fonte: OCDE - Indicadores principais de Ciência e Tecnologia, base 2000. Coordenação de Estatísticas e Indicadores do Ministério da Ciência e Tecnologia.

O resultado final é um desempenho tímido em relação à abertura de mercado, uma reação negativa por parte das empresas integrantes da amostra frente à concorrência e um desempenho muito aquém das necessidades do país no aspecto exportação.

O conceito de inovação, sua gestão e sua demanda financeira ainda necessitam grandes melhorias, pelo menos entre as empresas integrantes da amostra. 


\subsection{Discussões Futuras}

A inovação tecnológica dentro da indústria tem sido amplamente discutida entre governo e sociedade, mas ainda necessita maiores aprofundamentos e reflexões, tanto por parte da comunidade acadêmica, quanto elo governo e empresariado.

Esperamos que este trabalho possa servir como uma peça dentro deste complexo e importante jogo para a sociedade brasileira, que é o fortalecimento da base industrial, enriquecimento da sociedade e aprimoramento da mão de obra especializada do país.

Para um futuro próximo, esperamos continuar esta análise dentro do contexto das redes de cooperação industrial, formadas por pequenas e médias empresas, para que estas possam atingir o caminho da excelência tecnológica, assumindo lugar de destaque como geradoras de empregos, tecnologia e recursos financeiros à sociedade. 


\section{Referências Bibliográficas}

Atuaheme-Gima, K. e Patterson, P.; Managerial perceptions of technology licensing as an alternative to internal $R \& D$ in nem product development; an empirical investigation, R\&D Management, 1993, 41; Managerial perceptions of technology licensing as an alternative to internal $\mathrm{R} \& \mathrm{D}$ in nem product development; an empirical investigation, R\&D Management, 1993, 42

Bérgamo Filho, V.; Confiabilidade. Edgard Blucher, São Paulo, SP, 1997, 22

Breyfogle, F.W.; Implementing Six Sigma. John Wiley \& Sons, New York, EUA, 1999, 50; Implementing Six Sigma. John Wiley \& Sons, New York, EUA, 1999, 51

Brooking, A.; Intellectual Capital; core asset for the third millenium enterprise. International Thomson Busines Press, London, 1997, 31

Bryman, A.; Research methods and organizational studies. Unwin Hyman Ltd, London, 1989, 67

Camagni, R.; Innovation Networks; Spatial Perspectives. Belhaven Press, London, 1991, 44

Cantwell, J.; The internationalisation of technological activity and its implication for competitiviness. Cambridge Journal of Economics, 1995, 34

Castells, M.: ; A Sociedade em Rede. Editora Paz e Terra, São Paulo, SP, 1999., 10

Drucker, P.; Inovation and Entrepreneurship , 1985, 14

Edvinsson, L. \& Malone, M.; Intellectual capital; realizing your company's true value by finding its hidden roots. Harper Collins Publisher, New York, NY, 1997, 30

Fagerberg, J.; A technology gap approach to why growth rates differ, in; C. Freeman, Output Measurements in Science and Technology; Essais in honor of Y. Fabian, North Holland, Amsterdan, 1988, 34

Freeman C. e Perez, C., Structural crisis of adjustment: busines cycles and investiment behavior. In Dosi, G. et alli. Technical change and economic theory. London, Pinter Publisher, 1988., 16

Freeman, C.: The Economics of Industrial Innovation, 2nd. edn. Frances Pinter, London, 1982, 13

Galaskiewicz, J.; "The network analysis and its application to organizational theory and bahavior", e Araujo, L. e Easton, G., "Networks in socioeconomic systems" em Iacobucci, D., Networks in Marketing, Sage, London, 1996, 44

Galgano, A.; La Qualitá Totale. Il Company-Wide Quality Control come nuovo sistema manageriale. Ediciones Diaz de Santos, S.A., Madrid, Espanha, 1993, 51

Gibbons, M. et alli: ; New production of knowledge. London, Sage Publishers, 1996, 43

Gil, A.C.; Como Elaborar Projetos de Pesquisa. Editora Atlas S.A., São Paulo, SP, 1996, 66

Griffin, A.; Evaluating QFD's use in US firms as a process for developing products, Journal of Product Innovation Management, 1992, 54

Henderson, R. e Clark, K.; Architectural innovation; The reconfiguration of existing product technologies and the failure of stablished firmas, Administrative Science Quarterly, (1990), 17

Hollander, S.; The Sources of Increased Efficiency; A study of Dupont rayon plants. MIT Press, Cambridge, Massachussets, 1965, 17

Klein, D. \& Prusak, L.; "Characterizing Intellectual Capital ", artigo do programa multicliente, Ernest \&Young Center for Business Innovation, Boston, 1994, 31

Kline, S.J.e Rosemberg, N.: ; An Overview of Innovation. In Muniz, S., 43 
Malerba, F. e Orsenigo, L.: ; Technological regimes and firm behavior. In Muniz, S., 33

Mc Gee, J.E. e Dowling, M.J.; Using R\&D cooperative arrangements to leverage managerial experience, Journal of Business Venturing, 1994, 40

Merli, G.; Eurochallenge; The TQM approach to capturing global marckets. IFS Ltd, London, England, 1993, 49

Muniz S. Sambando em Gelo Fino - Investimento industrial, capacitação tecnológica e organizacional e competitividade brasileira nos anos 90. São Paulo, 2000. Tese (Doutorado) - Escola Politécnica, Universidade de São Paulo., 19

Nohria, N. e Eccles, R.G.; Networks and Organizations. Harvard Business School Press, Boston, 1991, 44

Porter, M.; The Competitive Advantage of Nations. Macmillan, London, 1990, 33

Porter, M.E. Estratégia Competitiva. Técnicas para a Análise de Indústrias e da Concorrência. $8^{\mathrm{a}}$ ed. Rio de Janeiro, 1998., 15

Prahalad, C.K. e Hamel, G.; The core competencies of the corporation. Harvard Business School Press, Cambridge, Mass, 1990, 31

Reichfeld, E.F.; The LoyalEffect, Harvard Business School Press, Harvard, 1996, 17

Sahal, D.; Patterns of Technological Innovation, Addison-Wesley, Massachussets, 1981, 24

Selltiz, C. et alii; Métodos de Pesquisa nas relações sociais, Editora Pedagógica e Universitária, São Paulo, 1985, 75

Stewart T.A.; Capital intelectual. Editora Campus, Rio de Janeiro, 1998, 32

Sveiby, K. E.; The New Organizational Wealth; managing and measuring knowledgebased assets, Berret-Koehler, Inc, San Francisco, 1997, 31

Terra, J.C.C.; Gestão do Conhecimento; Aspectos Conceituais e Estudo Exploratório sobre as Práticas de Empresas Brasileiras. Tese de Doutorado, Escola Politécnica USP, 1999, 30

Thillent, M.; Metodologia da pesquisa-ação. Ed. Cortez, São Paulo, 1985, 71

Tidd, J. e Trewhella, M.: Organizational and technological antecedents for knowledge acquisition, R\&D Management, in press, London, 1997, 46

Tidd, J. et alii, 32; :, 18; Managing Innovation, integrating Techonological, Market and Organizational Change. John Wiley \& Sons, London, England, 1997, 9

Utterback, J.; Mastering the Dynamics of Innovation. Publicação da Escola de Harvard, Boston, Massachussets, 1994, 19

Utterback, J. M.: ; Dominando a dinâmica da inovação. Editora Qualitymark, Rio de Janeiro, 1996., 59

Valeriano, D.,Gerência em Projetos - Pesquisa, Desenvolvimento e Engenharia. São Paulo, Makron Books, 1998, 23

Walsh, V.; Winning by Design; Technology, product design and international competitiveness. Basil Blackwell, Oxford, 1992, 18

Welch, J. A.; Strategic sourcing; a progressive approach to the make or buy decision, Academy of Management Executive, 1992, 40 


\section{Anexo 1. Questionário de avaliação aplicado entre as empresas. Prezado Senhor,}

O questionário que V.S.a está recebendo faz parte de uma Dissertação de Mestrado junto ao Departamento de Engenharia de Produção da Escola Politécnica da Universidade de São Paulo - USP, sob orientação do Prof. Dr. Roberto Giliolli Rotondaro, em associação com a Faculdade de Engenharia Industrial - FEI.

Sua empresa não será identificada! As informações e dados fornecidos por V.S.as serão mantidos em sigilo e incorporados à massa de dados que iremos trabalhar estatisticamente, de modo que estes não possam ser vinculados à sua empresa.

Caso seja de seu interesse, enviaremos os dados finais da pesquisa, via internet, esperando que estes dados ajudem os empresários a conhecerem-se melhor, bem como conhecerem melhor o segmento industrial onde atuam. Não haverá qualquer tipo de ônus, cobrança financeira ou venda, trata-se de uma pesquisa científica.

Respondendo este questionário V.S.a contribuirá para a elaboração de uma Dissertação de Mestrado, que poderá fornecer subsídios importantes aos setores empresarial e educacional do Estado de São Paulo. PARTICIPE ! AJUDE ！ DÊ SUA OPINIÃó

O questionário é aparentemente longo, porém sua resposta é muito simples e rápida, podendo ser feita em poucos minutos, diretamente na tela, através de múltipla escolha. Após o preenchimento, as respostas poderão ser encaminhadas diretamente ao email talamo@ifxbrasil.com.br, bastando apenas clicar sobre este endereço eletrônico.

Agradecemos antecipadamente sua colaboração, Atenciosamente,

Engenheiro José Roberto Tálamo

Mestrando em Engenharia de Produção

Escola Politécnica da USP

Docente da Faculdade de Engenharia Industrial - FEI 


\section{Questionário - Parte 1 - Dados da Empresa}

Obs.: Há um glossário de termos técnicos usados neste questionário, ao final do mesmo, para sua consulta, se necessário:

Perfil Profissional de quem responde este questionário.

Indique suas respostas com um " $\mathrm{X}$ "nos quadros cinza

\begin{tabular}{|l|l|l|}
\hline 1. Área onde trabalha & Diretoria Geral & \\
\hline & Marketing ou Vendas & \\
\hline & Financeiro & \\
\hline & Planejamento & \\
\hline & Produção & \\
\hline & Qualidade & \\
\hline & Desenvolvimento & \\
\hline & Recursos Humanos & \\
\hline 2. Cargo & Presidente & \\
\hline & Diretor & \\
\hline & Gerente & \\
\hline & Outros(indicar): & \\
\hline
\end{tabular}

Perfil da Empresa (Se não quiser responder a algum campo, deixe-o em branco)

\begin{tabular}{|l|l|}
\hline 3. Nome da empresa & \\
\hline 4. Razão Social & \\
\hline 5. Endereço e CEP & \\
\hline 6. Cidade & \\
\hline
\end{tabular}

\begin{tabular}{|l|l|l|}
\hline 7. n. ${ }^{\text {total de funcionários: }}$ & Menos de 5 & \\
\hline & De 5 a 10 & \\
\hline & De 11 a 20 & \\
\hline & De 21 a 40 & \\
\hline De 41 a 60 & \\
\hline De 61 a 80 & \\
\hline & De 81 a 100 & \\
\hline & Mais de 100 & \\
\hline
\end{tabular}

\begin{tabular}{|l|l|l|}
\hline $\begin{array}{l}\text { 8. n. } \\
\text { empresa: } \\
\text { empe engenheiros que trabalham na }\end{array}$ & Nenhum & \\
\hline & 1 a 3 & \\
\hline & 4 a 6 & \\
\hline & 7 a 9 & \\
\hline & 10 ou mais & \\
\hline
\end{tabular}


9. Principal produto/especialidade da empresa:

9.1 Antenas para transmissões e recepção de imagem e som

9.2 Aparelhos e equipamentos de sinalização, alarme e publicidade

9.3 Aparelhos e equipamentos de telefonia e radiotelefonia

9.4 Aparelhos e equipamentos elétricos para fins eletroquímicos

9.5 Aparelhos e equipamentos para comunicação e entretenimento

9.6 Aparelhos e utensílios para fins industriais, rurais e comerciais

9.7 Aparelhos elétricos para usos doméstico e pessoal

9.8 Aparelhos para recepção e reprodução de imagem e som

9.9 Caldeiras e geradores de vapor

9.10 Componentes elétricos estampados

9.11 Componentes elétricos

9.12 Condutores elétricos

9.13 Cronômetros e relógios eletrônicos, peças e acessórios

9.14 Equipamentos periféricos para máquinas eletrônicas

9.15 Lâmpadas, peças e acessórios

9.16 Máquina e aparelhos para indústria de produtos alimentares

9.17 Máquinas aparelhos e equipamentos pneumáticos

9.18 Máquinas e aparelhos para refrigeração e ventilação

9.19 Máquinas operatrizes e aparelhos para indústria de obras em metais e carbonetos metálicos

9.20 Máquinas, aparelhos e equipamentos de sistemas eletrônicos para processamento de dados

9.21 Máquinas, aparelhos e equipamentos de sistemas eletrônicos p/ automação gerencial

9.22 Máquinas, aparelhos e equiptos para geração, transmissão, distribuição, medição e controle

9.23 Máquinas, aparelhos e equipamentos para indústria química

9.24 Máquinas, aparelhos e equipamentos para medição

9.25 Material elétrico

9.26 Material elétrico para veículos, peças e acessórios

9.27 Material eletro eletrônico e de comunicação

9.28 Material eletrônico básico

9.29 Material para instalações elétricas

9.30 Motores elétricos

9.31 Peças e acessórios p/ aparelhos e equip.tos de comunicação, imagem, som e entretenimento

9.32 Peças e acessórios para máquinas e aparelhos elétricos

9.33 Peças e acessórios para máquinas, aparelhos e equipamentos de informática

9.34 Pilhas, acumuladores e seus componentes

9.35 Reparo de máquinas, aparelhos e equipamentos elétricos industriais e comerciais

9.36 Software

\begin{tabular}{|l|l|l|}
\hline 10. Capital da empresa: & $100 \%$ nacional & \\
\cline { 2 - 3 } & $100 \%$ estrangeiro & \\
\cline { 2 - 3 } & Misto (nacional +estrangeiro) & \\
\cline { 2 - 3 } & Participação governamental & \\
\hline
\end{tabular}


11. A posição de mercado da empresa, em sua especialidade é de:

\begin{tabular}{|l|l|}
\hline Líder & \\
\hline Segunda posição & \\
\hline Terceira posição & \\
\hline Não sei & \\
\hline Outras (especifique) & \\
\hline
\end{tabular}

\begin{tabular}{|c|c|}
\hline 12. O faturamento anual & Menos de $10.000,00$ \\
\hline bruto, em US dólar, é de: & de $10.001,00$ a $20.000,00$ \\
\hline & de $20.001,00$ a $30.000,00$ \\
\hline & de $30.001,00$ a $40.000,00$ \\
\hline Obs.: considere $1 \mathrm{US} \$ \cong$ & de $40.001,00$ a $50.000,00$ \\
\hline $\mathrm{R} \$ 2,00$ a fim de facilitar & de 50.001,00 a $60.000,00$ \\
\hline seu raciocínio. & de $60.001,00$ a $70.000,00$ \\
\hline & de $70.001,00$ a $80.000,00$ \\
\hline (Obs.: cotação de & de $80.001,00$ a $90.000,00$ \\
\hline 14/01/2000 dá 1US\$ = & de $90.001,00$ a $100.000,00$ \\
\hline & de $100.001,00$ a $150.000,00$ \\
\hline & de $150.001,00$ a $200.000,00$ \\
\hline & de $200.001,00$ a $300.000,00$ \\
\hline & de $300.001,00$ a $500.000,00$ \\
\hline & de 500.001,00 a 1 milhão \\
\hline & Mais de 1 milhão \\
\hline
\end{tabular}

13. Sua participação de mercado, em sua especialidade é de:

\begin{tabular}{|l|l|}
\hline Menos de $10 \%$ & \\
\hline De 10 a $20 \%$ & \\
\hline De 20 a $30 \%$ & \\
\hline De 30 a $50 \%$ & \\
\hline Mais de $50 \%$ & \\
\hline Não sei & \\
\hline
\end{tabular}

\begin{tabular}{|l|l|l|}
\hline 14. Nos últimos 2 & Ganhou mercado acentuadamente & \\
\hline \multirow{4}{*}{\begin{tabular}{l} 
anos, a empresa: \\
\cline { 2 - 3 }
\end{tabular}} & Ganhou mercado levemente & \\
\hline & Manteve mercado & \\
\hline & Perdeu mercado levemente & \\
\hline & Perdeu mercado acentuadamente & \\
\hline
\end{tabular}

\begin{tabular}{|l|l|l|}
\hline \multirow{4}{*}{$\begin{array}{l}\text { 15. As exportações } \\
\text { correspondem a: }\end{array}$} & Até $10 \%$ do faturamento & \\
\hline & 11 a $20 \%$ do faturamento & \\
\hline & 21 a $30 \%$ do faturamento & \\
\hline 31 a 50\% do faturamento & \\
\hline & Mais de 50\% do faturamento & \\
\hline & Não exporta & \\
\hline
\end{tabular}




\begin{tabular}{|l|l|l|}
\hline $\begin{array}{l}\text { 16. O impacto da abertura do mercado } \\
\text { brasileiro para sua empresa foi: }\end{array}$ & Excelente & \\
\cline { 2 - 3 } & Muito bom & \\
\hline & Bom & \\
\hline & Indiferente & \\
\hline & Negativo & \\
\hline & Muito negativo & \\
\hline
\end{tabular}

\section{Questionário - Parte 2 - Aspectos Administrativos}

Nesta parte do questionário serão feitas avaliações sobre o aspecto inovador da empresa, ou seja, aspectos referentes à busca de novas tecnologias e o processo de geração de novos produtos.

Obs.: Procure sempre indicar as respostas que mais se aproximem de sua realidade. Quando houver a possibilidade de mais de uma resposta, numere-as por ordem de importância, atribuindo o número 1 à mais importante, o número 2 à segunda mais importante, etc.

\begin{tabular}{|l|l|l|}
\hline 17. Onde você acredita que & No preço dos seus insumos & \\
\cline { 2 - 3 } $\begin{array}{l}\text { se encontra a maior } \\
\text { oportunidade de inovação }\end{array}$ & Na demanda do mercado & \\
\cline { 2 - 3 } $\begin{array}{l}\text { que sua empresa pode } \\
\text { utilizar? }\end{array}$ & Nos seus fornecedores & \\
\cline { 2 - 3 } $\begin{array}{l}\text { Cite no máximo duas seus clientes } \\
\text { oportunidades. }\end{array}$ & Na tecnologia disponível & \\
\cline { 2 - 4 } & Na concorrência & \\
\cline { 2 - 4 } & Na qualificação dos funcionários & \\
\cline { 2 - 3 } & Outros (especifique, se quiser): & \\
\hline
\end{tabular}

\begin{tabular}{|l|l|l|}
\hline 18. Na sua opinião, quais os aspectos & O próprio produto & \\
\cline { 2 - 3 } $\begin{array}{l}\text { mais importantes a serem analisados } \\
\text { quando se comparam produtos entre }\end{array}$ & Os serviços & \\
\cline { 2 - 3 } $\begin{array}{l}\text { concorrentes? } \\
\text { Cite no máximo três aspectos. }\end{array}$ & Prazos de entrega & \\
\hline & O preço & \\
\cline { 2 - 3 } & Tecnologia envolvida & \\
\cline { 2 - 3 } & Outros(cite, se quiser): & \\
\hline
\end{tabular}

\begin{tabular}{|l|l|l|}
\hline 19. Que fonte de informação você & O produto do concorrente & \\
\cline { 2 - 3 } $\begin{array}{l}\text { mais utiliza para comparar-se aos } \\
\text { concorrentes? }\end{array}$ & Análise de patentes & \\
\cline { 2 - 3 } Cite no máximo duas fontes. & Publicações especializadas & \\
\cline { 2 - 3 } & Benchmarking & \\
\hline & Pesquisa de mercado & \\
\cline { 2 - 3 } & Outras (cite, se quiser) & \\
\cline { 2 - 3 } & Nada / Nenhuma fonte & \\
\hline
\end{tabular}




\begin{tabular}{|c|c|}
\hline 20. Em sua opinião, & Pesquisa e desenvolvimento próprios \\
\hline qual o modo mais & Joint ventures (uniões) \\
\hline adequado para obter & Através dos fornecedores \\
\hline novas tecnologias? & Através dos clientes \\
\hline Cite no máximo três & Pagando royalts (licenciamento) \\
\hline fontes de tecnologia. & Engenharia reversa \\
\hline & Leasing \\
\hline & Feiras ou eventos similares \\
\hline & "Chupando" \\
\hline & Universidades \\
\hline & Pesquisa contratada (encomendada) \\
\hline & Outras (cite, se quiser) \\
\hline
\end{tabular}

\begin{tabular}{|c|c|}
\hline \multirow{8}{*}{$\begin{array}{l}\text { 21. O que você acha melhor } \\
\text { para manter a vantagem } \\
\text { competitiva sobre os } \\
\text { concorrentes? } \\
\text { Cite no máximo duas } \\
\text { respostas. }\end{array}$} & Segredo profissional \\
\hline & Acúmulo de conhecimento \\
\hline & Pesquisa interna \\
\hline & Rapidez para chegar ao mercado \\
\hline & Redução sistemática de custos \\
\hline & Ter patentes \\
\hline & Ter um produto complexo \\
\hline & Outras (cite, se quiser) \\
\hline
\end{tabular}

\begin{tabular}{|l|l|l|}
\hline $\begin{array}{l}\text { 22. Que categoria } \\
\text { você classificaria } \\
\text { como mais próxima }\end{array}$ & $\begin{array}{l}\text { Fornecedor } \\
\text { cospecializado (pouca concorrência) }\end{array}$ & \\
\cline { 2 - 3 } $\begin{array}{l}\text { da especialidade de } \\
\text { sua empresa? }\end{array}$ & Fornecedor majoritário & \\
\cline { 2 - 3 } & Fornecedor minoritário & \\
\cline { 2 - 3 } & Fornecedor sob encomenda / contratado & \\
\cline { 2 - 3 } & Produtor final em larga escala & \\
\cline { 2 - 3 } & $\begin{array}{l}\text { Produtor final em pequena escala } \\
\text { Produtor final tecnologicamente } \\
\text { especializado (pouca concorrência) }\end{array}$ & \\
\cline { 2 - 3 } & Outras (cite, se quiser) & \\
\hline
\end{tabular}

\begin{tabular}{|l|l|l|}
\hline $\begin{array}{l}\text { 23. Onde você acha que está } \\
\text { situada sua maior competência }\end{array}$ & Na tecnologia interna & \\
\cline { 2 - 3 } empresarial? & Competência de seu pessoal & \\
\cline { 2 - 3 } & Na sua área de P\&D & \\
\cline { 2 - 3 } & Na área de compras & \\
\cline { 2 - 3 } & Na logística de distribuição & \\
\cline { 2 - 3 } & Na área de vendas & \\
\cline { 2 - 3 } & Outras (cite, se quiser) & \\
\hline
\end{tabular}


24.Com o surgimento da internet, os fabricantes de aparelhos de fax sofreram forte perda de mercado. Recentemente, a IBM e a Philips lançaram softwares de comando de voz, que representam igual ameaça aos teclados. Você identifica alguma ameaça à sua empresa, em função da evolução tecnológica?

\begin{tabular}{|l|l|}
\hline sim & \\
\hline não & \\
\hline talvez & \\
\hline Não sei & \\
& \\
\hline
\end{tabular}

25. Do mesmo modo que no caso anterior, você vê alguma oportunidade para sua empresa, em função da evolução tecnológica?

\begin{tabular}{|l|l|}
\hline Sim & \\
\hline Não & \\
\hline Talvez & \\
\hline Não sei & \\
\hline
\end{tabular}

26. Sua empresa tem uma estrutura formal fixa (pessoas, Sim área, equipamentos, etc.) voltada à inovação? não

27. Qual o porcentual de seu faturamento despendido no desenvolvimento de alguma inovação ao longo deste ano?

\begin{tabular}{|l|l|}
\hline 0 & \\
\hline Até $1 \%$ & \\
\hline Entre $1 \%$ e $3 \%$ & \\
\hline Acima de $3 \%$ & \\
\hline
\end{tabular}

28. No momento, você está desenvolvendo alguma inovação tecnológica, objetivando algum novo produto? não

\begin{tabular}{|c|c|}
\hline 29. Na sua opinião, qual o melhor & P\&D internos \\
\hline veículo para indicação de novas & Pesquisa de Mercado \\
\hline tendências tecnológicas, ainda em & Pesquisa informal \\
\hline sua fase inicial ? & Através dos fornecedores \\
\hline (independente de você usar, já ter & Através dos clientes \\
\hline usado ou nunca ter usado qualquer & Literatura especializada \\
\hline um dos veículos) & Periódicos e publicações \\
\hline & Através dos concorrentes \\
\hline Neste caso, você poderá escolher & Associações de classe \\
\hline três veículos, atribuindo 1 para & Universidade \\
\hline significativo, 2 para $\mathrm{o}$ & Feiras e eventos \\
\hline & Outros (especificar) \\
\hline
\end{tabular}




\begin{tabular}{|c|c|}
\hline \multirow{4}{*}{$\begin{array}{l}\text { 30. Indique as ferramentas } \\
\text { estatísticas que você utiliza } \\
\text { em seus processos de } \\
\text { produção e desenvolvimento: }\end{array}$} & Análise de Pareto \\
\hline & Cartas de CEP \\
\hline & Coleta de dados de processo \\
\hline & Diagrama de Correlação \\
\hline \multirow{5}{*}{$\begin{array}{l}\text { Indique todas que utilizar } \\
\text { usando o número } 1 \text { para a que } \\
\text { julgar mais importante, } 2 \text { para } \\
\text { o seguinte, etc. }\end{array}$} & Diagrama Ishikawa \\
\hline & Histogramas \\
\hline & Delineamento de experimentos \\
\hline & Nenhuma \\
\hline & Outras (indicar) \\
\hline
\end{tabular}

\begin{tabular}{|l|r|r|}
\hline 31. Seus processos de produção são & Sim & \\
\cline { 2 - 3 } documentados (normas, procedimentos, folhas & Não & \\
\cline { 3 - 4 } de processo, etc.)? & Parcialmente & \\
\hline
\end{tabular}

\begin{tabular}{|l|r|r|}
\hline 32. Seus processos de desenvolvimento de & Sim & \\
\cline { 2 - 3 } produto são documentados (normas, & Não & \\
\cline { 2 - 3 } procedimentos, etc.)? & Parcialmente & \\
\hline
\end{tabular}

\begin{tabular}{|l|r|r|}
\hline 33. Suas análises de processos de produção são & Sim \\
\cline { 2 - 3 } documentadas (normas, procedimentos, folhas & Não \\
\cline { 2 - 3 } de processo, etc.)? & Parcialmente \\
\hline
\end{tabular}

\section{Questionário - Parte 3 - Aspectos de Relacionamento com o ambiente externo.}

\begin{tabular}{|l|l|l|}
\hline $\begin{array}{l}\text { 34. Você utiliza algum método } \\
\text { para avaliar as necessidades e }\end{array}$ & QFD & \\
\cline { 2 - 3 } expectativas do seu cliente? & Método Delphi & \\
\cline { 2 - 3 } Indique todas que utilizar & Pesquisa de mercado & \\
\cline { 2 - 3 } & Linha telefônica 0800 & \\
\cline { 2 - 3 } & Internet & \\
\cline { 2 - 3 } & Outros (citar) & \\
\cline { 2 - 3 } & Nenhum & \\
\hline
\end{tabular}

\begin{tabular}{|l|l|l|}
\hline \multirow{3}{*}{35. Você conhece o perfil de seu cliente? } & Sim & \\
\cline { 2 - 3 } & Não & \\
\cline { 2 - 3 } & parcialmente & \\
\hline
\end{tabular}

\begin{tabular}{|l|l|l|}
\hline $\begin{array}{l}36 . \text { Você trabalha em parceria com seus } \\
\text { fornecedores? }\end{array}$ & Sim & \\
\cline { 2 - 3 } & Não & \\
\cline { 2 - 3 } & Parcialmente & \\
\hline
\end{tabular}


37. Sua empresa tem procedimentos escritos e Sim documentados que estabelecem como desenvolver Não um fornecedor?

38. Você já fez acordo ou parceria cedendo parte de Sim seus negócios em troca de tecnologia?

Não

39. Já trabalhou ou trabalha para o governo e/ou estatais?

\begin{tabular}{|l|l|}
\hline Sim & \\
\hline Como sub fornecedor & \\
\hline Não / Nunca & \\
\hline
\end{tabular}

40.Caso sua resposta anterior tenha sido Estimulado sim (exclusivamente), você achou que o Facilitado acesso à tecnologia foi:

Dificultado

Negado

Desnecessário

41. Já trabalhou ou trabalha para multinacionais?

\section{Sim}

Como sub fornecedor

Não / Nunca

42. Caso sua resposta anterior tenha sido sim (exclusivamente), você achou que o acesso à tecnologia foi:

\begin{tabular}{|l|l|}
\hline Estimulado & \\
\hline Facilitado & \\
\hline Dificultado & \\
\hline Negado & \\
\hline Desnecessário & \\
\hline
\end{tabular}

Questionário - Parte 4 - Mecanismos de Implementação.

\begin{tabular}{|l|l|l|}
\hline 43. Você elabora orçamentos (budget) & Sim & \\
\cline { 2 - 3 } formalmente, todos os anos, para planejar & Não & \\
\cline { 2 - 3 } seus gastos e despesas? & Parcialmente & \\
\hline
\end{tabular}

\begin{tabular}{|l|l|l|l|}
\hline 44. Caso sua resposta anterior tenha sido sim & Sim & \\
(exclusivamente), você planeja gastos ou & Não & \\
investimentos com inovações tecnológicas?
\end{tabular}


45. Considere, por exemplo, a Imediatamente necessidade de implementar Alguns dias (até 5 dias) uma modificação de médio Poucas semanas $(\approx 2)$ porte (ferramental ou Ao redor de 1 mês equipamento de pequeno porte) Poucos meses $(\approx 2)$ em seu processo ou produto. De 3 a 6 meses Você diria que essa alteração Mais de 6 meses seria implantada.....

\begin{tabular}{|l|l|l|}
\hline 46. Em sua empresa, & Sempre & \\
as modificações de & Quando necessário (cliente pede) & \\
\cline { 2 - 3 } processo e/ou produto & As vezes & \\
são documentadas & Muito pouco & \\
\cline { 2 - 3 } (desenhos/registros)? & Nunca & \\
\hline
\end{tabular}

47. Você tem um documento específico (norma ou $\operatorname{Sim}$ procedimento) que estabelece como registrar Não modificações?

48. Que tipos de instrumentos de apoio CAE sua empresa tem para projetos, CAD alterações, desenvolvimentos, etc.? indique todos os que existirem

\section{Questionário - Parte 5 - Contexto interno.}

\begin{tabular}{|l|l|l|}
\hline 49. Em sua empresa, uma & Questão de oportunidade. & \\
\cline { 2 - 3 } inovação (que possa gerar & Motivo de procura & \\
\cline { 2 - 4 } $\begin{array}{l}\text { novo produto ou novo } \\
\text { processo) é vista como: }\end{array}$ & Objetivo claro & \\
\cline { 2 - 2 } & Estratégia de sobrevivência & \\
\hline
\end{tabular}

\begin{tabular}{|l|l|l|}
\hline 50. A estrutura organizacional de sua empresa & Funcional & \\
é do tipo funcional (hierárquica, com chefes, & & \\
gerentes, etc.) ou por processo (não há & Processo & \\
hierarquia, o que manda é o processo de & & \\
desenvolvimento e/ou fabricação)? & & \\
\hline
\end{tabular}


51. Em sua opinião, sua empresa dá margem à criatividade de seus colaboradores?

\begin{tabular}{|l|l|} 
Sim & \\
\hline Não & \\
\hline Às vezes & \\
\hline
\end{tabular}

52. Existe um método formal de coleta de novas Sim idéias? Obs.: Considere isto algo superior a "caixa Não de sugestões". Pense em termos de idéias novas!

53. Sua empresa tem um programa formal de Sim treinamento e formação de seu pessoal? Não

\begin{tabular}{|l|l|l|}
\hline $54 . \quad$ Como você & Instantâneo & \\
\cline { 2 - 3 } classificaria o processo & Muito ágil & \\
de comunicação dentro & Ágil & \\
de sua empresa? & Lento & \\
(comunicação de de & Muito lento & \\
mudanças em produtos, & Falho (às vezes não há inform.) & \\
\cline { 2 - 3 } $\begin{array}{l}\text { alterações de processos, } \\
\text { técnicas de produção, }\end{array}$ & Não existente & \\
etc.) & & \\
\hline
\end{tabular}

Este espaço é destinado aos comentários ou observações que você queira fazer. Escreva à vontade!

$\Rightarrow$

Deseja receber o resultado da pesquisa?

Sim

\section{Agradeço imensamente sua ajuda!}

Glossário:

1. Benchmarking: Processo de desenvolvimento de produtos ou processos, utilizandose como base os melhores aspectos de cada concorrente do mercado.

2. CAE: Computer Aided Engeneering - Execução de ferramentais e insumos com o auxílio de programas de computador. 
3. CAD: Computer Aided Design - Execução de projetos com o auxílio de programas de computador.

4. CAM: Computer Aided Manufactorin - Administração de processo de manufatura com o auxílio de programas de computador,

5. CEP: Controle Estatístico de Processos

6. Delineamento de experimentos: Análise de processo baseada na matriz de variáveis mais significativas, que são analisadas em conjunto com as demais

7. Joint Ventures: Uniões de risco, estabelecidas entre empresas, com a finalidade de desenvolverem produtos e/ou processos em parcerias.

8. Leasing: Locação de bens (máquinas e equipamentos) com opção de compra.

9. Método Delphi: Pesquisa de mercado destinada a mapear as necessidades e objetivos do cliente.

10. P\&D: Pesquisa e desenvolvimento.

11. QFD: Quality Function Deployment - Análise preliminar de projeto, efetuada ainda na fase de concepção do produto, levando-se em conta todas as necessidades e objetivos do cliente, futuro usuário. 
JOSÉ ROBERTO TÁLAMO

O Processo de Inovação nas Indústrias de Pequeno e Médio Porte do Estado de São Paulo - Setores da Eletro Eletrônica e Telecomunicações.

Dissertação apresentada à Escola Politécnica da Universidade de São Paulo - Departamento de Engenharia de Produção - como parte do processo de obtenção do título de Mestre em Engenharia.

São Paulo 
Errata: Dissertação de Mestrado:

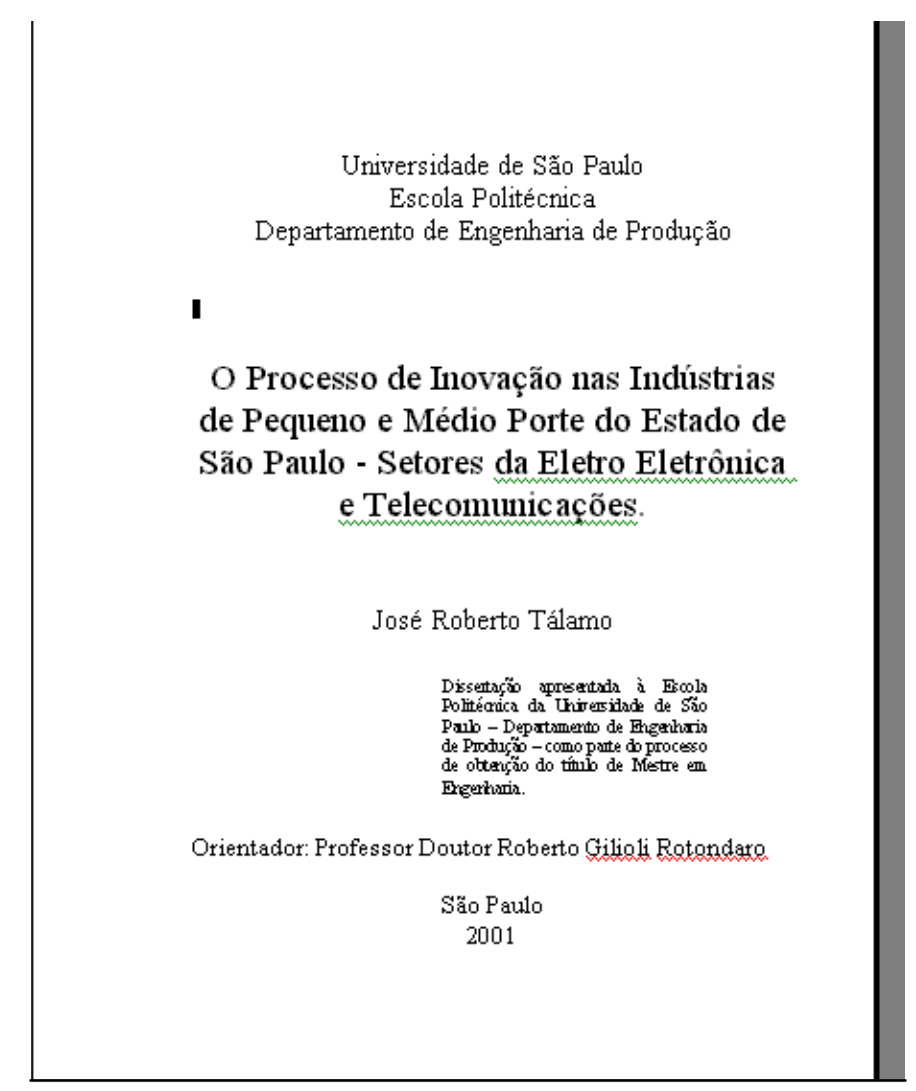

- Página 18, Item 2.1.5, segundo parágrafo:

Onde se lê: A figura 2 a seguir....

Leia-se: A figura 3 a seguir....

- Página 54, figura 14, último quadrante das abscissas:

Onde se lê: Planejamento e produção do novo produto

Leia-se: Planejamento da qualidade e produção do novo produto

- Página 75, Item 3.6.3 Amostragem:

Não considerar a linha onde se lê: Fundação Parque de Alta Tecnologia São Carlos - ParqTec São Carlos.

- $\quad$ Página 111, penúltimo parágrafo, $2^{\mathrm{a}}$ linha:

Onde se lê: ...integrantes da amostra frente e um desempenho.....

Leia-se: ...integrantes da amostra frente à concorrência e um desempenho..... 